\title{
LA TIERRA DEL TORO. ENSAYO DE IDENTIFICACIÓN DE CIUDADES VASCONAS
}

\author{
POR
}

\author{
ALICIA M. ${ }^{a}$ CANTO \\ Universidad Autónoma de Madrid
}

\section{RESUMEN}

Este trabajo está dividido en dos partes. En la primera se estudian los testimonios de culto al toro y a la luna como definidores del territorio primitivo del ager Vasconum, en especial las muy características «aras taurobólicas» de Navarra y el Oeste de Zaragoza. En la segunda se propone un nuevo método de análisis, por conjuntos, para intentar aprovechar datos, hoy inutilizables, del geógrafo Ptolomeo (II, 6, 66), acerca de las ciudades vasconas. Con diversos materiales arqueológicos y fuentes literarias, antiguas y medievales, se llega a proponer nueva ubicación para dieciocho de ellas y, en especial, para el enorme territorio público conocido como «Las Bárdenas Reales», un posible ager Caesarianus adsignatus. La propuesta final de localizaciones (fig. 13) coincide bastante bien con la experimental a partir de Ptolomeo (fig. 9), lo que puede indicar la validez del método empleado.

\section{SUMMARY}

This paper is divided into two parts. The first one deals with the evidences of the worship to the bull and the moon, especially the most characteristic «aras taurobólicas» (Navarra and W. of Saragossa), as defining elements of the ager Vasconum original territory. In the second part a new method of analysis, sectoral, is proposed on order to try and make use of some of geographer Ptolomey's (II, 6, 66) up to now unusable facts concerning the Vasconic towns. Various ancient and medieval archaelogical and literary sources will suggest new locations for eighteen such towns, notably for the huge territory known as «Bárdenas Reales» (presently uninhabited), perhaps an ager Caesarianus adsignatus. The final map (fig. 13) seems to match fairly well the experimental one (fig. 9) based on Ptolemy, hinting thus at the soundness of the method employed.

\section{LA TIERRA DEL TORO: LAGUBEGI, FARASDUÉS, UJUÉ, LA ESTELA DE LUNA Y EL LÍMITE SUDORIENTAL VASCÓN}

Retomo los comentarios y paralelos citados a propósito de una nueva estela epigráfica de Pueyo, Navarra (Canto-Iniesta-Ayerra, e.p.), en cuanto a las numerosas estelas y aras vasconas que representan cabeza, cuerpo o cuernos de toro, en clara relación con la divinidad lunar propia del norte hispano. És- tas se nos ofrecen en el ámbito doméstico ${ }^{1}$, en el religioso $^{2}$, y en el funerario ${ }^{3}$, a cuyos grupos deben pertenecer también fragmentos indeterminados del Museo de Navarra ${ }^{4}$, incluido uno de la vecina Artajona ${ }^{5}$, siendo la misma diversidad de ambientes prueba de la influencia cotidiana de este dios en el pueblo vascón. Me gustaría ahora apuntar algo más en relación con este culto al llamado noble bruto en la Navarra Media, que excede el actual territorio foral tanto por el $\mathrm{O}$, muy ligeramente (hasta la línea de La Guardia de Álava) como hacia el E, penetrando bastante en la actual provincia de Zaragoza, hasta al menos Farasdués.

El mapa (fig. 1) de su distribución en el territorio vascón ofrece, por un lado, 20 estelas y altares (varios de éstos sobre aras rituales, anepigráficas) en los que se presentan o bien la cabeza sola del toro o bien su cuerpo completo. Y, por otro, otras 20 estelas funerarias (fig. 2) en las que el cuerno lunar me parece representar a un idéntico dios, depositario del mismo sentimiento religioso que las anteriores. He añadido en el mapa las cinco inscripciones votivas al Júpiter romano. Creo que el conjunto de

1 Así las dos «aras» del santuario de la villa de Arellano (Mezquíriz, 1993-1994: 61, 81). O el grupo de aras taurobólicas (Eslava-Sos-Bañales-Sofuentes-Artajona: Uranga, 1966), completado ahora con las cuatro de Farasdués, $Z$. (Aguarod-Mostalac, 1983: 329, lám. V), posiblemente aún en territorio vascón, $v$. infra.

${ }_{2}$ Por ejemplo en el frontón del ara de Júpiter de Aibar (Castillo et al., 1981: n 17, lám. XVII) y, muy destacada en altorrelieve, en ambos laterales del ara al dios Lacubegi de Ujué (ibid.: $\mathrm{n}^{\circ} 34$, lám. XXXIVb y $c f$. infra).

${ }^{3}$ Aparte de la de Carcastillo, las de Gastiain (Castillo et al., 1981: $\mathrm{n}^{\circ} 42$, lám. XLII) y posiblemente Eslava (ibid.: $\mathrm{n}^{\circ}$ 41 , lám. XLI), entre otras varias.

${ }^{4}$ Así, en la misma zona, los ya citados de Eslava (ibid.: $\mathrm{n}^{\circ}$ 74 , lám. LXXIV) y, algo más alejados, los dos de Sos del Rey Católico (núms. 80, 81, láms. LXXX, LXXXI).

5 Aquí fig. 3, no 7 . La publicó primero J.E. Uranga (1966: 224 con lám. V). J.M ${ }^{\mathrm{a}}$ Jimeno Jurío (1968: 13 con n. 9 y 76 n. 503), se refiere a «un fragmento de lápida romana decorada con cabeza de toro" procedente, no de Artadía, como decía Uranga, sino del sitio artajonés de Guencelaya, como ingresada en el Museo de Navarra en 1966. No figura, sin embargo, en el citado catálogo del Museo. 


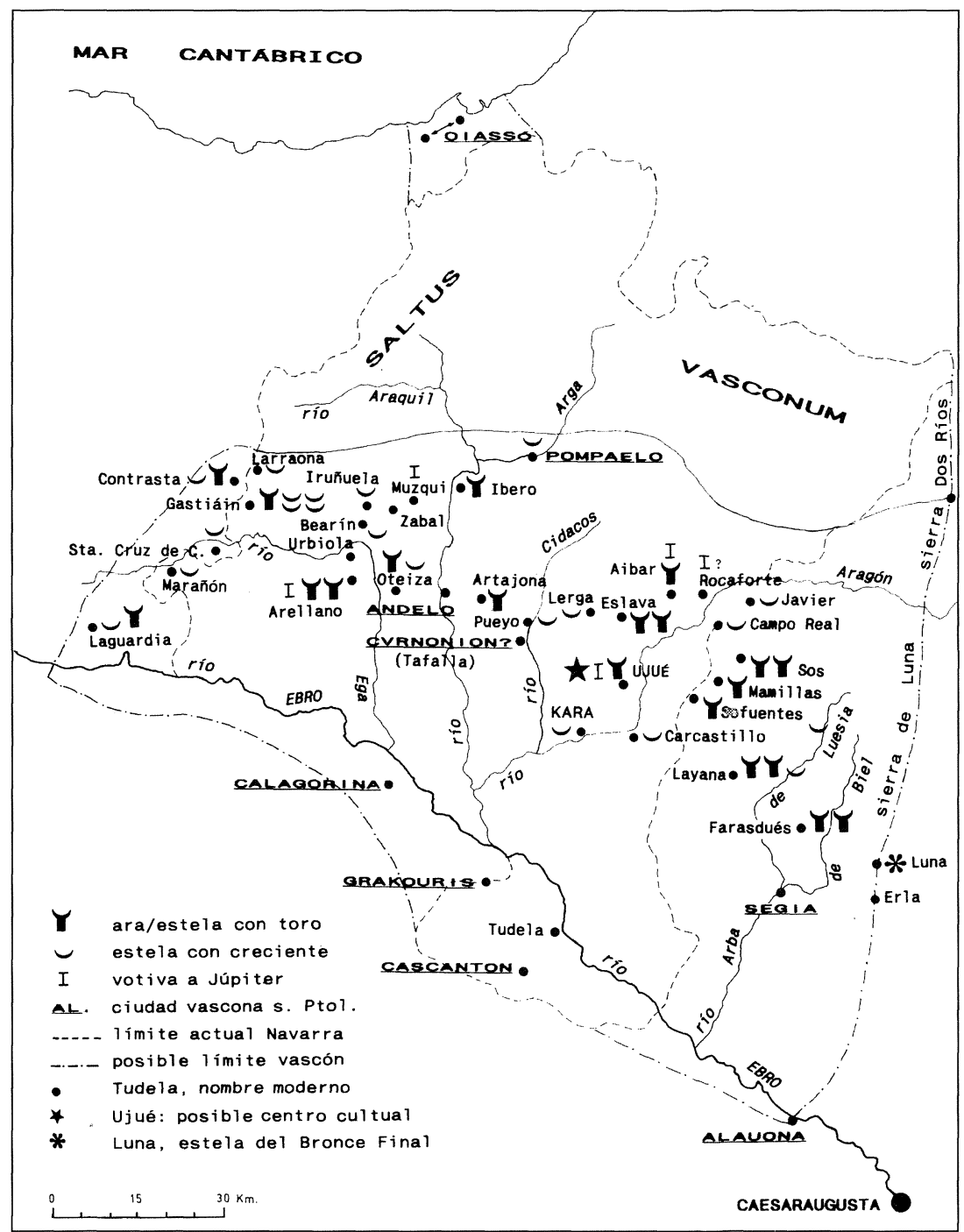

Fig. 1.-Distribución en el ager Vasconum de las estelas y aras con motivos tauro-lunares (mapa de A. Canto y S. Luzón).

todos estos hallazgos define perfectamente lo que más propiamente puede considerarse el ager Vasconum, siendo el punto más septentrional, significativamente, la propia Pompaelo. Sobre las relaciones de la misma simbología lunar con otras muestras de áreas celtibéricas como Burgos y Soria, o incluso galaicas, como Vigo, ya se ha comentado algo en el citado trabajo, aunque debe indicarse que estas similitudes no alcanzan a lo que parece muy y más propio vascón, las llamadas «aras taurobólicas» (fig. 3) de las que la más expresiva es sin duda la de Sos (Z.), hoy en el Museo de Navarra (fig. 4$)^{6}$.

${ }^{6}$ Parece un tipo de monumento específico vascón. Además, son significativos los topónimos antiguos y modernos de
Mención aparte merece ahora la causa por la que he incluido en el mapa el original grupo de cinco estelas de Aguilar de Codés, con varias figuras humanas, vestidas habitualmente con saga, dentro de nichos, estudiadas hace años, entre otros, por A. Marcos Pous (1972: 317-328; Castillo et al., 1981, s.v., $c f$. ahora un recuento ilustrado en García-Blázquez, 1994: 318-320 con fig. 2), que se agrupan con algunas otras navarras (Gastiáin) y del otro lado de la frontera alavesa: Las dos de Contrasta y otra, quizá la mejor del lote, de Santa Cruz de Campezo ${ }^{7}$.

esta área que tienen relación con cornu: Aparte de la ciudad ptolemaica de Curnonion (cf. infra): Hoya de Cornaba, Barranco de Cornava, Cornoino, Cornago, Vilar de Cornu, etc. junto a cognomina romanos como Cornutus y Cornutinus. 




Fig. 2.-Estela funeraria de Porcius Felix de Carcastillo (NA.) (Foto cortesía del Museo de Navarra).

Sobre este singular grupo (fig. 5), de dos o tres figuras humanas de pie que en cinco ocasiones se to-

7 No incluyo los ejemplares de San Román de San Millán ni Narvaja, por encontrarse al Norte de la Sierra de Urbasa, aunque compartan la misma idea y aspectos iconográficos. Se ha propuesto con dudas que también tuviera figuras humanas una nueva inscripción de Olite (Canto-Iniesta-Ayerra, e.p.). man de la mano, se han dado algunas interpretaciones, desde que pueden ser retratos, familiares (Marcos Pous-García Serrano, 1972: 324; García-Blázquez, ibid.) o idealizados (Elorza, 1970: passim) de los fallecidos, a que se trata de tríadas/trinidades celtas, o de la multiplicación de la figura del difunto para heroizarlo (Marco Simón, 1978: 44-45). En cinco ejemplares aparecen junto a ellas, o sujetos por ellas, algunos objetos, como lo que se viene interpretando como una carda de lana (Marcos PousGarcía Serrano, ibid.) o un peine, símbolo de «atildamiento, de duelo o de dignidad y victoria en la muerte» (Marco Simón, 1978: 59). En dos estelas alguna de las figuras sostiene un «cetro rematado en bola» (Marcos Pous-García Serrano) o «falces» (Marco Simón).

Por el contrario, pienso que unas figuras que se cogen de la mano no pueden hacer otra cosa sino bailar. Los objetos entonces, especialmente las «cardas o peines» (Aguilar, Santa Cruz, Marañón) deben de ser más bien instrumentos musicales, tales como caramillos o flautas rústicas (syringes, fistulae). Los alargados, «con bolas», quizá sean entonces liras o guitarras muy simples, las pandurae (como en Aguilar) y los «triángulos y cuadrados», como los del fragmento de Zabal (Castillo et al., 1981: $\mathrm{n}^{\circ}$ 82), esquilas o campanas. Las «falces» de la estela de Santa Cruz podrían ser simples trigona, es decir, triángulos de cuerda. Las «lanzas» serán meros palos, como los que siguen usándose en algunas danzas vascas ${ }^{8}$. Como puede verse, todo ello bastante rústico y muy ligado, como cabe esperar, al mundo silvo-pastoril y ganadero.

Pero creo que es la estela de Santa Cruz de Campezo ya mencionada (fig. $5 n^{\circ} 6$ ) la que puede proporcionar el mejor indicio para esta interpretación que sugiero; ya que, presidiendo la escena de preparación o término de la danza, vemos un gran creciente lunar entre las dos consabidas hexapétalas. Habrá que recordar entonces el celebérrimo paso estraboniano sobre los pueblos del norte hispano (III, 4, 16): «Todos los celtíberos y los otros pueblos del Norte, excepto los galaicos, tienen cierta divinidad desconocida a la que, en las noches de luna llena, las familias rinden culto, danzando durante toda la noche ante las puertas». La mención de «las familias» ya de por sí

${ }^{8}$ Caro Baroja (1945: 116 ss., por ejemplo el paloteado o makil-dantza de Vera de Bidasoa). Más difícil es entender el objeto que pende de la mano de la figura del fragmento de Gastiáin (Castillo et al., 1981: no 76), que puede semejarse más a un sistro o a crótalos. Los objetos de Santa Cruz podrían ser flautas dobles, incluso aunque terminen en punta de flecha, a juzgar por el paralelo de una flautista, pintada en un pithos de La Serreta de Alcoy (Blázquez, 1975: 78 fig. c). $C f$. Caro Baroja, 1996: 505 ss. 

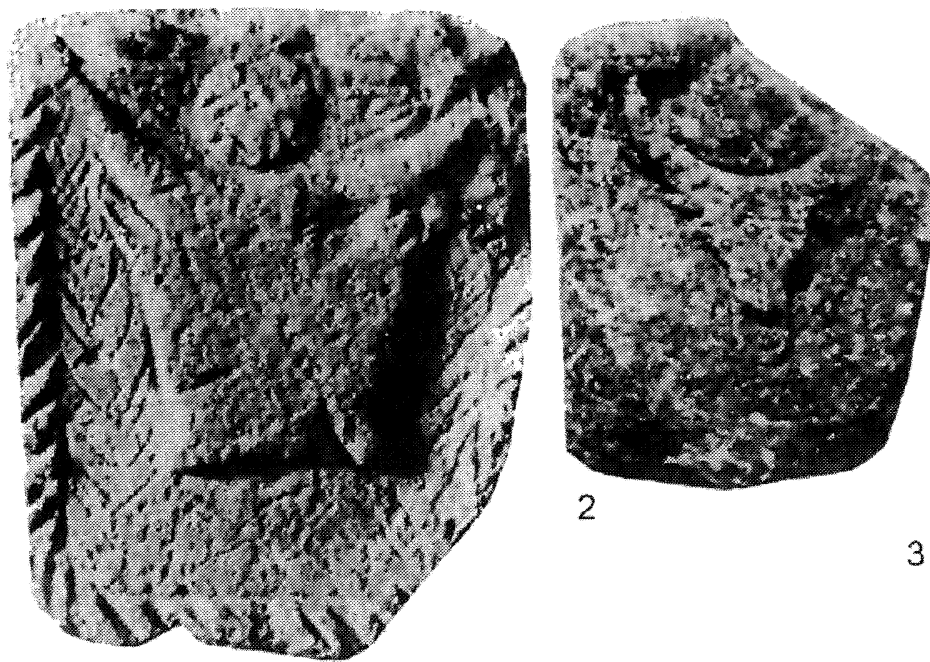

2

3

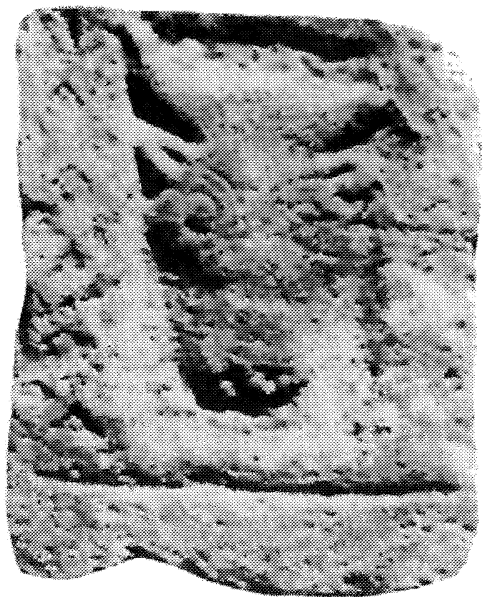

1
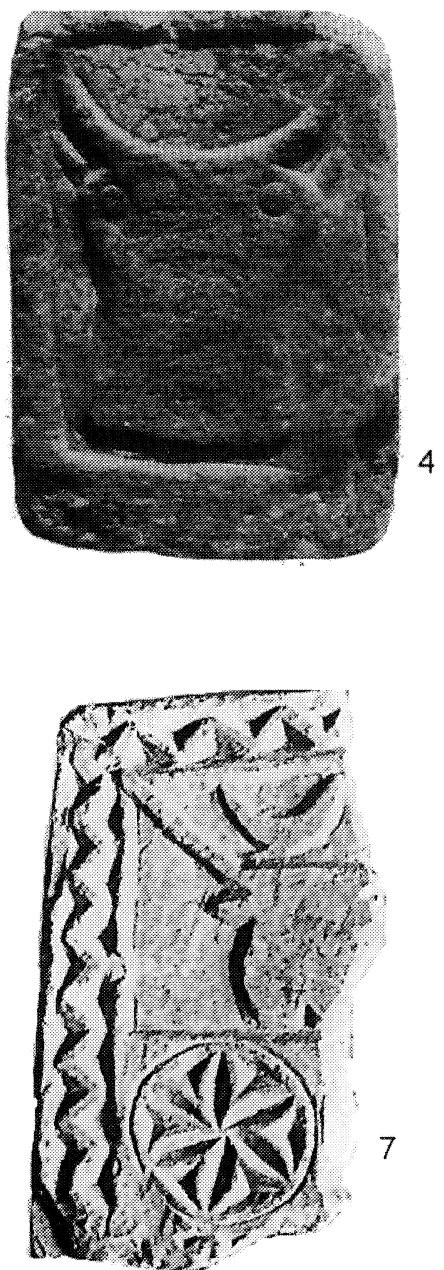

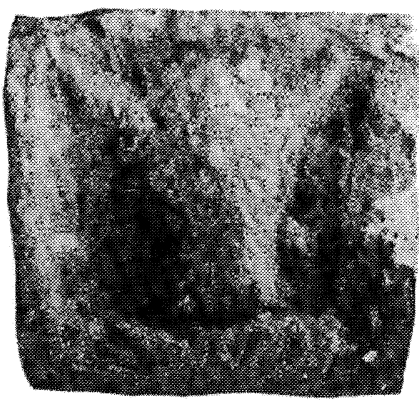

5
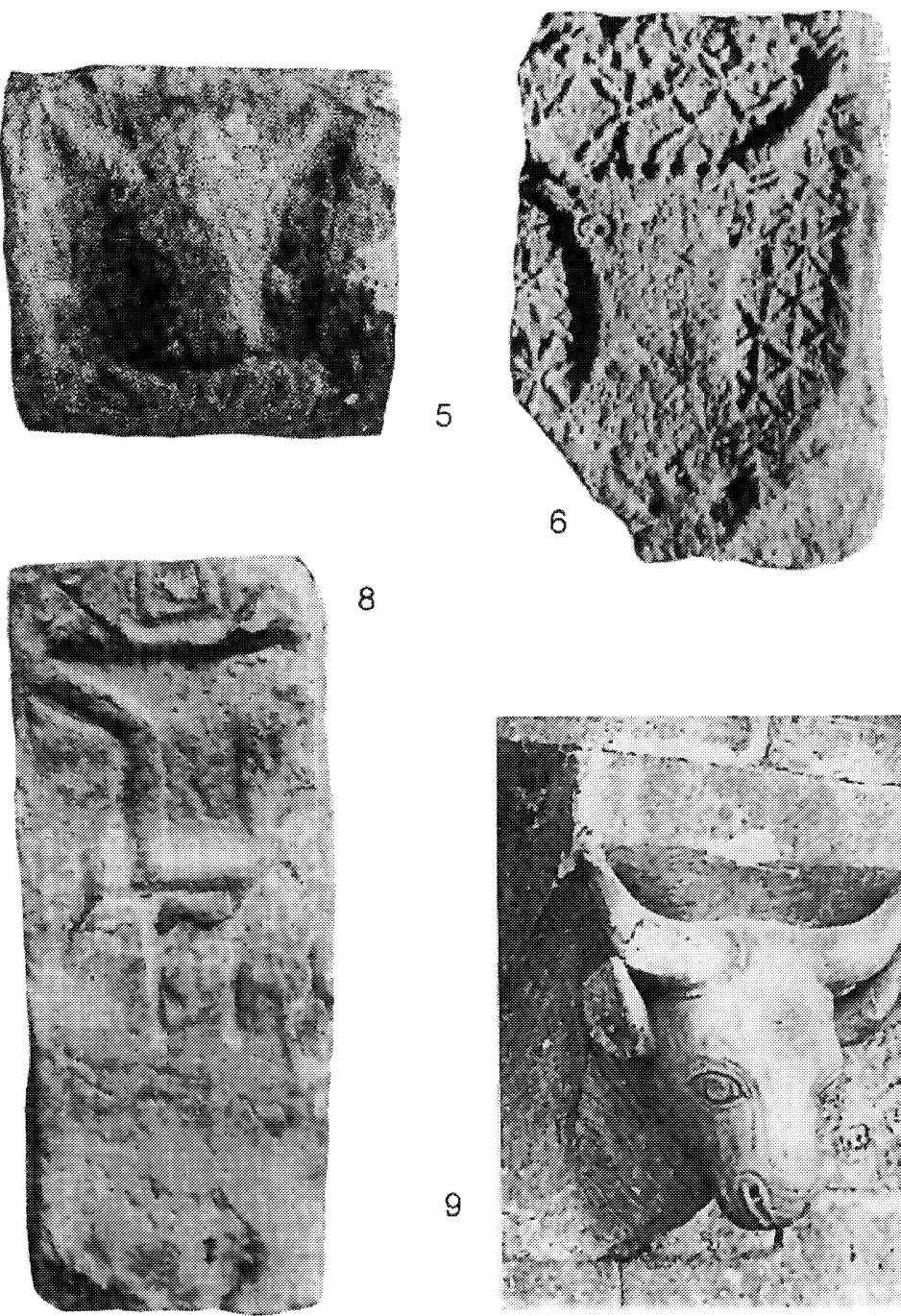

8

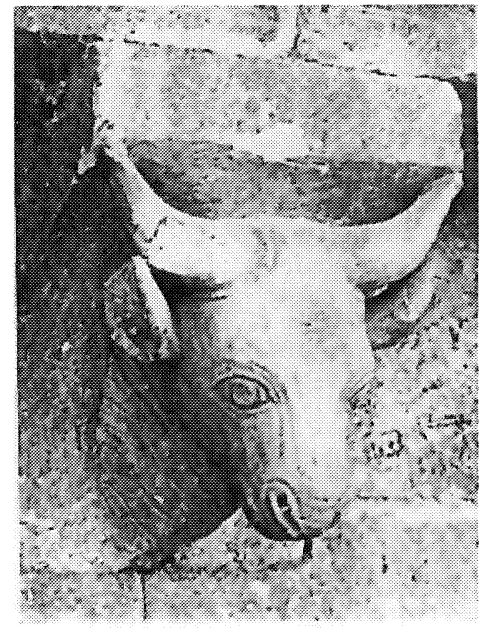

Fig. 3.-Aras y sillares taurobólicos de Navarra y Zaragoza. 1) Sos. 2) Eslava. 3 y 5) Los Bañales. 4) Sos. 6) Sofuentes. 7) Artajona. 8) Farasdués. 9) Canecillo del ábside del monasterio de Irache, siglo XII (según Uranga, 1966 y Aguarod-Mostalac, 1983). 


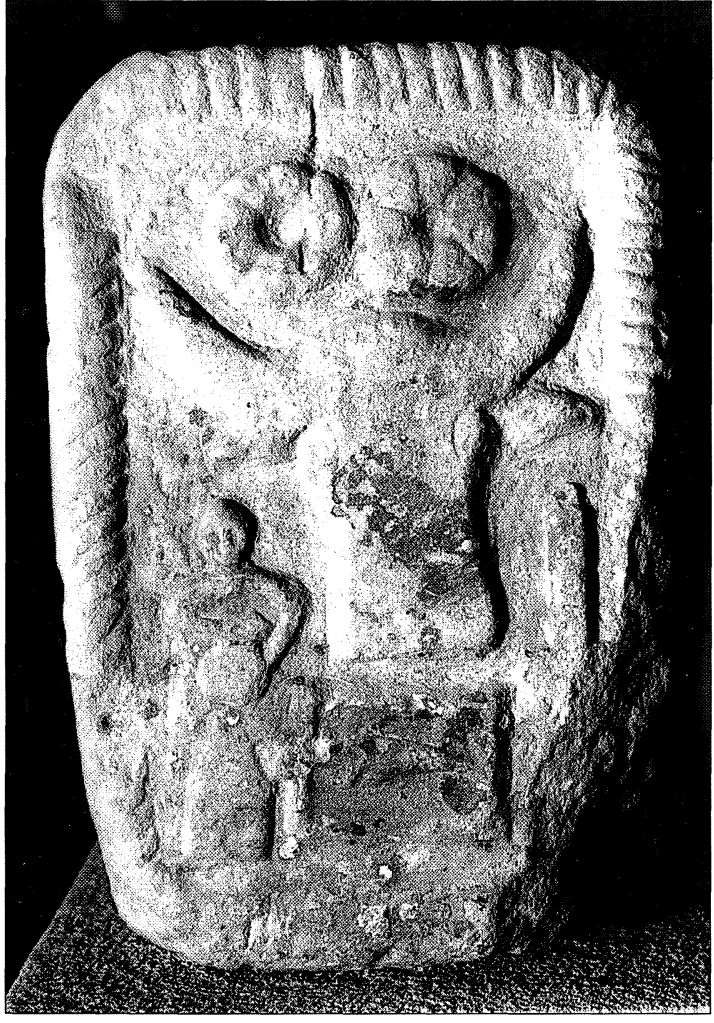

Fig. 4.-Ara taurobólica de Sos del Rey Católico (Zaragoza). (Foto cortesía del Museo de Navarra).

da idea de que varias personas o grupos participan en estos bailes (con dimensión ritual no colectiva en Sayas, 1994a: 234); que éstos serían o cogidos de la mano (Aguilar de Codés, cuatro ejemplos) o, al modo eslavo, por los hombros, como vemos en la de Urbiola (Marco Simón, 1978: $n^{\circ}$ N 38 y fig. 30, aquí fig. $5 n^{\circ} 8$ ). No se concibe, por otra parte, un baile sin instrumentos o música, por primitiva y sencilla que ésta sea, e incluso acompañado de cantos: Qué tentación entonces recordar los choros Rixamarum de Marcial, celtíberos o mejor vascones ( $c f$. infra, s.v. Tutela), cuando el párrafo de Estrabón citado usa justamente el verbo choreúo.

Si una vez al mes, por honrar al dios, por atraerse sus favores o aplacar sus iras, bailaban toda la noche, con mayor motivo, me parece, lo harían en ocasión de tanta solemnidad y necesidad de protección como el fallecimiento de uno de sus miembros. El que aparezcan en varias ocasiones las figuras delante de espacios arquitectónicos, o entre pilares y columnas (pylai, cuando son distintas de las del Hades), creo que refuerza esta hipótesis. En estas singulares estelas se evocaría, pues, un momento del ritual funerario. Bajo tales supuestos espero haber encontrado apoyo suficiente para considerar también entre los monumentos relacionados con el culto a la luna los de este peculiar grupo del occidente navarro-alavés, y justificar así su inclusión en el territorio y en el mapa de la iconografía del culto lunar; una relación que, como decía, está además a la vista en la estela de Santa Cruz de Campezo.

Por último, conviene recordar en este preciso contexto la justamente célebre estela de Narhunges, Abisunhari filius (fig. 6), hallada en Lerga, NA. (Castillo et al. 1981: $\mathrm{n}^{\circ}$ 50), dedicada a un joven difunto de 25 años, probablemente por su primo ${ }^{9}$ Umme, Sahari f(ilius), porque quizá pueda atribuirse con más provecho a este mismo grupo. Se trata de una familia más acomodada, tanto en sentido económico (parece un joven jinete) como cultural, a la región en la que vive, a cuya más habitual cabecera semicircular se ciñe la estela. Pero véase la composición central: Bajo la línea primera del epígrafe, entre dos crecientes lunares (quizá mejor que «guirnaldas»), hay un marco arquitectónico como los de la Sierra de Codés, sólo que columnado; en él aparecen dos figuras en plena danza fúnebre, levantando sus manos, que se unen a través del objeto rectangular que entre ambas sostienen. Como aquí sí parece tratarse de soldados, quizá de commilitones, y el de la derecha sujeta, esta vez claramente, una lanza, quizá en este caso sí pueda decirse que muestran la urna cineraria del difunto (así pensó Marco Simón, 1978: ${ }^{\circ}$ N 29, y véase también la de Narvaja, Álava), o danzan con ella, aunque el objeto, con sus laterales elevados, no se preste a encontrarle paralelos arqueológicos. Parece así que tenemos en Lerga a un joven originario de la zona occidental vascona, enterrado lejos de su tierra. Y entonces su onomástica, quizá la más vasco-aquitana de toda Navarra, al decir de L. Michelena, parcce indicarnos quiénes eran, menos romanizados pero en contacto, los habitantes primigenios de la Sierra de Codés, a lo mejor llamados Cuda/enses. Puede, por tanto, que por el lado occidental el límite del ager Vasconum pudiera precisarse más por esta meridiana ${ }^{10}$. Después de estas consideraciones

9 No entro ahora a reflexionar sobre la unánimemente aceptada lectura de L. Michelena, salvo en su última línea. El desarrollo propuesto, t(itulum) p(osuit) s(umptu) s(uo), me parece refinado e inesperable en la zona. Por tanto, y en vista de que las relaciones familiares se remarcan tanto en los epígrafes funerarios del área y de que aquí se ha puesto especial cuidado en precisar también la filiación del dedicante, propondría desarrollar t(estamento) p(osuit) s(obrino) $s($ uо $)$.

${ }^{10} \mathrm{El}$ resto de las estelas del conjunto, entre las que conservan el epígrafe, ofrecen ya una onomástica, en general, más indoeuropea, es decir, o céltica o latina. M. Gómez Moreno hablaba de la división de Navarra en dos zonas lin- 

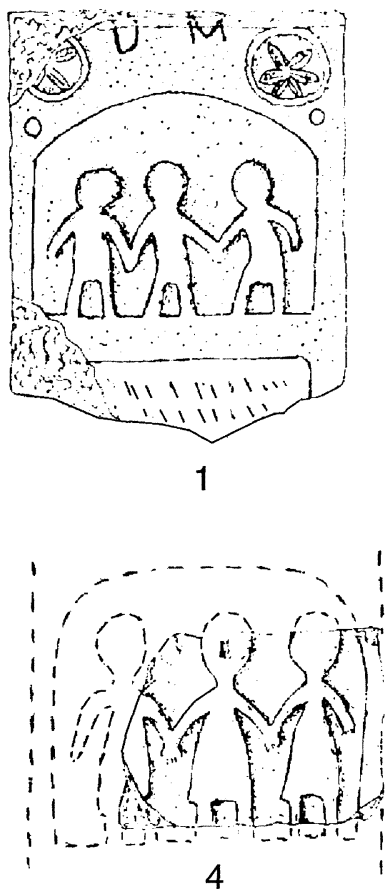

4



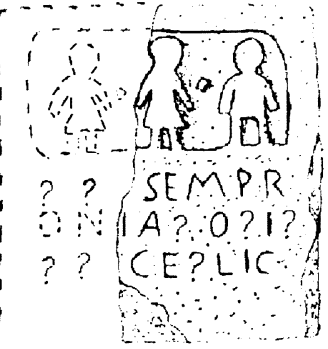

2

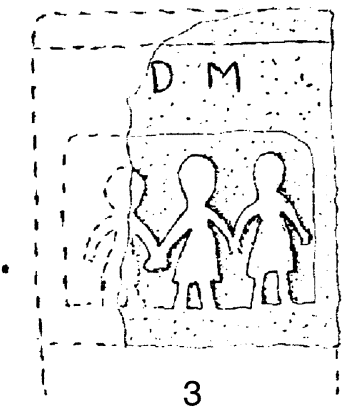

3

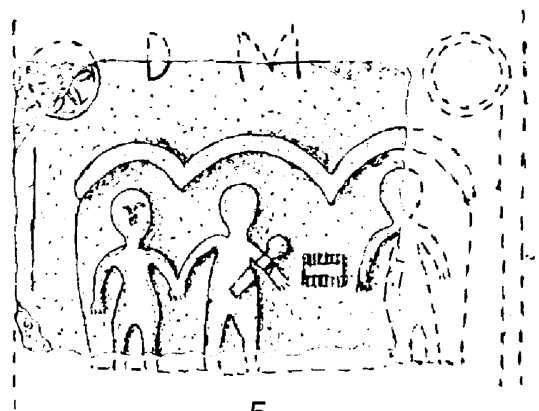

5
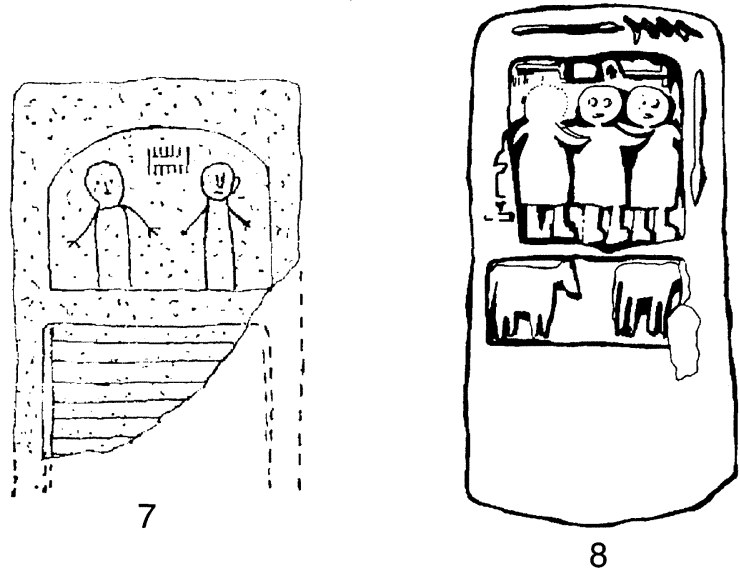

Fig. 5.-Estelas de «danzantes» del tipo Codés. 1-5) Aguilar de Codés, NA. 6) Sta. Cruz de Campezo, Álava. 7) Marañón, NA. 8) Urbiola, NA. (según Marcos Pous-García Serrano, 1972 y García Gelabert-Blázquez, 1994: n. ${ }^{\circ} 8$ ).

sobre el oeste vascón, podemos plantearnos ya si la distribución a la que hemos llegado con un mapa de

güísticas, ésta occidental, coincidente en parte con la Tierra Estella, en estrecho parentesco onomástico con el E. de Álava, con una fuerte indoeuropeización. Para otro autor reciente (Gorrochategui, 1987: 437), las dos téseras de Viana demuestran que esta zona ya próxima a la Rioja era berona y, por tanto, celtibérica. Parece, por tanto, que, de no ser los testimonios religiosos puede ser expresiva también para la definición geográfica de la zona este, y si

mencionados en la estela de Lerga aquitanos, debían ser vascones del límite occidental del saltus. C. Sánchez Albornoz (1976: 18 con nota 10), atendiendo a los límites dialectales del vasco actual, hacía discurrir la frontera con várdulos y berones entre los valles del Oyarzun y el Urumea, las sierras de Urbasa, Andía y Aralar, y el valle del Ega. 


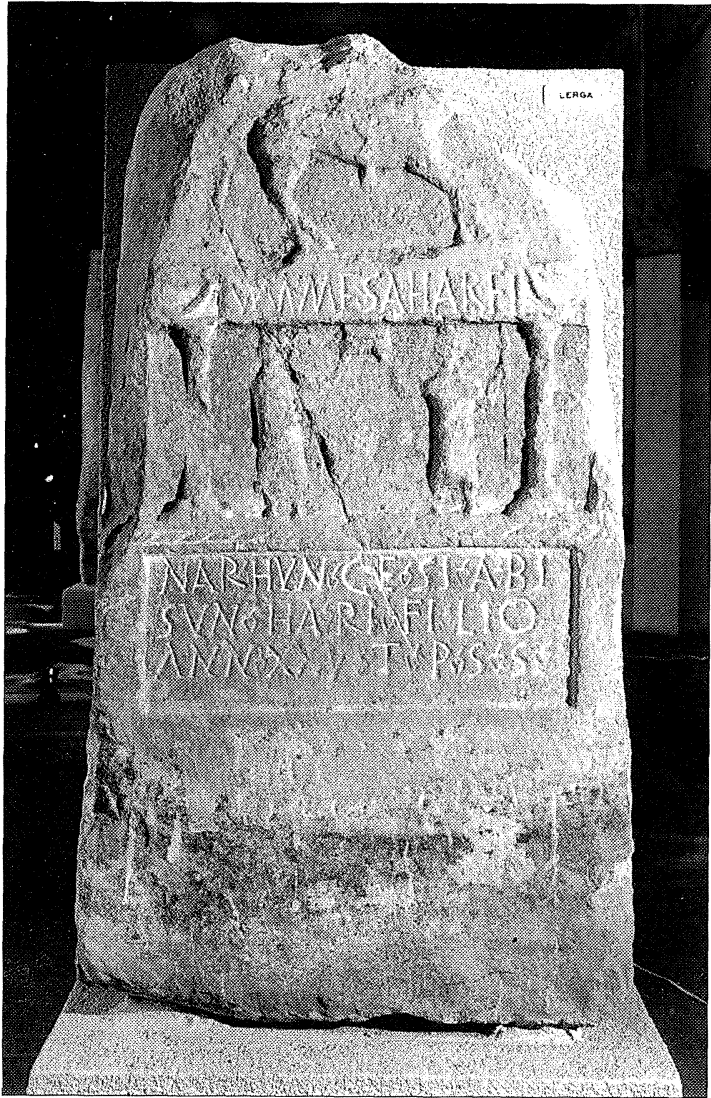

Fig. 6.--Estela de Lerga (NA.). (Foto cortesía del Museo de Navarra).

podría detectarse algún posible centro para este llamativo culto tauro-lunar.

Sabemos que por el E el territorio vascón llegaba al menos hasta la vertical marcada por Alauo/Alagón y Segia/Ejea, al decir de Ptolomeo (Peréx Agorreta, 1986: 63 y lám. XVII; Asensio 1995: 53, 80, 107). Pero quizá se podría hacer la propuesta concreta de que el límite sudoriental lo marcaran precisamente la Sierra de Luna y el municipio del mismo nombre. Por un lado, son claras alusiones, topo- y oronímica, al venerado astro. ¿Más razones? M.C. Aguarod y A. Mostalac dejaron constancia de un importante detalle al publicar (1983: 312) las cuatro aras taurobólicas de Farasdués, aunque no sacaron de él ninguna conclusión: Que, de las cuatro aras, la $\mathrm{n}^{\circ} 3$ se hallaba in situ y erguida aún al descubrirla y que «la cabeza de toro del ara miraba hacia el Noroeste».

Éste me parece importante detalle para la siguiente hipótesis: En la dirección a la que se dirigía este ara (y posiblemente todas las demás en su momento), se encuentra Ujué. El santuario de Ntra. Sra. de Ujué se considera desde hace siglos, y hoy aún,

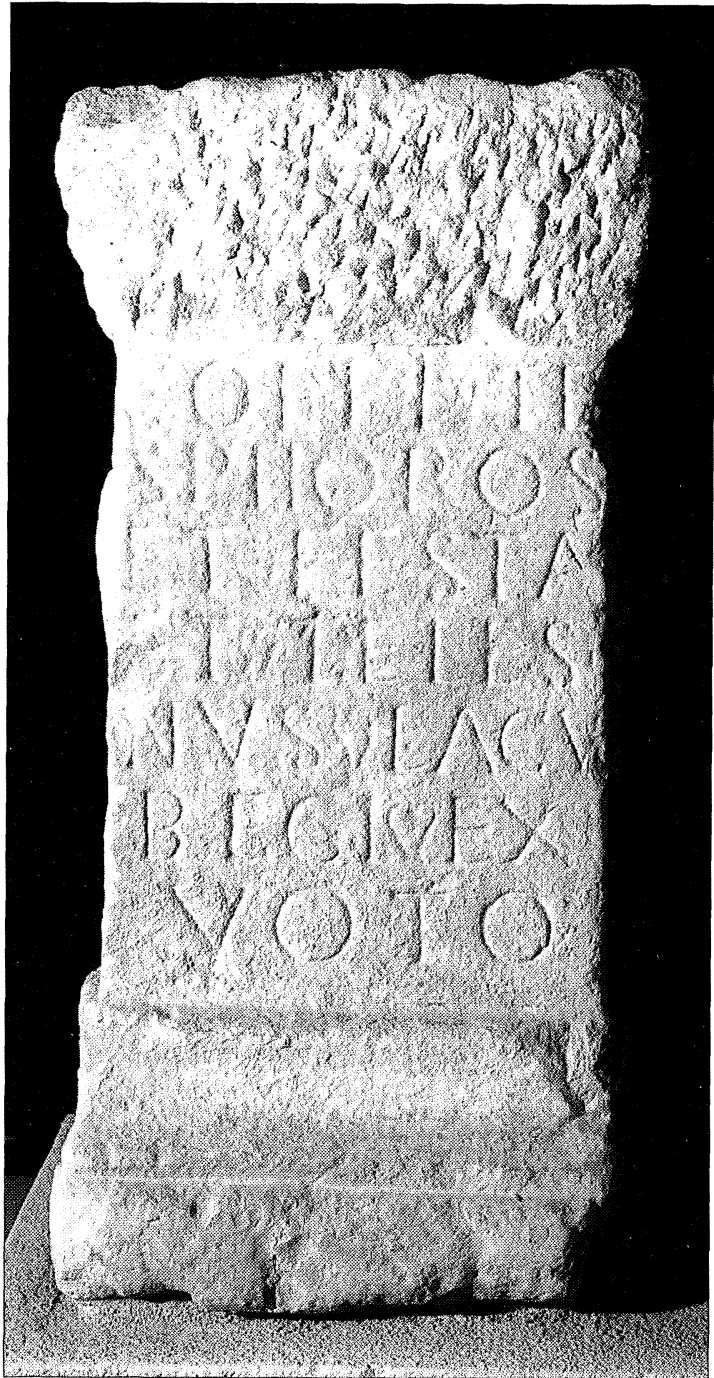

Fig. 7.-Ara de Ujué (NA.) dedicada a Lacubegi. Tiene cabezas de toro en ambos laterales. (Foto cortesía del Museo de Navarra).

patrón y protector de todo el piedemonte navarro hasta La Ribera y su lugar de peregrinación. Y de allí proceden también las dos aras que más atrás citamos " , una de Júpiter y otra similar, de los mismos dedicantes ${ }^{12}$ pero con cabezas de toro y consagrada a Lacubegi (fig. 7): «El ojo que ayuda», «el ojo que

\footnotetext{
"Castillo et al., 1981: núms. 33 y 34 (ILER 10 y 860).

12 Considero muy forzado tomar esta doble dedicación de Ujué como un caso de «ambigüedad indígena» o de "resistencia a las divinidades romanas», tal como sugieren González, Loizaga y Relloso (1987: 422), puesto que no parece que nadie les obligara a ofrendar dos aras. Los dedicantes de Ujué tienen nombres latinos y griegos, son de condición libertina, e incluso ignoramos su origo. Es más bien un caso evidente de interpretatio.
} 
acompaña», si lo pudiéramos explicar por el euskera: lagu-begi ${ }^{13}$. Las aras de Farasdués, ya muy cerca del límite vascón ${ }^{14}$, se volvían pues, como a una meca, hacia el santuario principal del dios cornúpeto y lunar que, a veces representado por el toro o su cabeza, a veces mediante los simples cuernos, comunes a ambos, encontramos, protegiéndoles aún, en sus estelas fúnebres en tantos lugares de Navarra y del oeste zaragozano. Solicitando la misma protección, como hoy se vuelven las plegarias del llano hacia la Virgen que ocupó su elevado y vigilante lugar, «centro religioso local de la región» (Mensúa, 1960: 165; Ciérbide en: Tafalla, 1990, 33-47) ${ }^{15}$.

$\mathrm{El}$ «ojo» más grande y vigilante que los antiguos podían conocer era la luna misma el día de su plenilunio. Y, mientras éste faltaba, el astro iba adoptando la forma de los cuernos del toro en dos fases, decreciente y crecientemente ${ }^{16}$. No es extraño, pues, que estimaran a este animal como una especie de

13 Habitualmente se le considera un dios relacionado con el agua por el elemento céltico lacu- (Blázquez, 1975: 111; Sayas, 1994a: 243; id. 1994b: 419) o también con su poder fecundante. El mismo J. M. Blázquez (1983: 248) recoge innumerables leyendas y prácticas folklóricas posteriores en este sentido genésico y viril, pero no creo que pueda explicarse por esta cualidad su frecuente presencia en las estelas funerarias ( $c f$. infra n. 18). J.C. Elorza (1972: 363) comenta la opinión de $\mathrm{M}^{\mathrm{a}} \mathrm{L}$. Albertos, relacionándolo con fuentes o manantiales, a través de un supuesto ide. lacu-bex. J.J. Sayas (1994b: 419), citando a J.M. Iraburu, recuerda también la pervivencia del nombre de un barranco inmediato a Ujué como «de Lacubeli» (aunque ello no implica necesariamente relación con el agua, sino sólo con el nombre del vecino santuario). R. Ciérbide (en: Tafalla, 1990: 37-38) cita además allí los microtopónimos «Laco» y «Lacumulatu».

${ }_{14}$ Unos $3.5 \mathrm{Km}$ al E. de Farasdués y a unos $700 \mathrm{~m}$. escasos del «Corral Viejo de Moncho», lugar del hallazgo, se encuentra el sitio de «La Raya», con evidente significado limital. Lo mismo ocurre con el microtopónimo del yacimiento del «Cantal de la Higuera», cf. infra n. 85. Menos de 7 $\mathrm{Km}$ al E están ya la Sierra de Luna y el municipio de igual nombre, al SO.

${ }^{15} \mathrm{El}$ otro punto navarro donde se encontraron in situ dos aras con cabezas de toro es la capillita de una villa, en Arellano (Mezquíriz, 1993-1994: 85 y plano 3). Miran ligeramente hacia el SO, en dirección a Sartaguda y Lodosa. Creo que aquí se trata de otra comarca vascona y problemática, por hallarse ya al Oeste del río Ega. Pero recuérdese que los mismos dedicantes de Ujué consagraron otra ara a Júpiter: Pues de Arellano procede otro epígrafe, quizá no casualmente también al mayor de los dioses, Iuppiter, con el apelativo de Apenninus (Castillo et al., 1981: $\mathrm{n}^{\circ}$ 18). Aunque se tratara de una promesa hecha en un viaje por Italia, el hecho de que sea Júpiter el dios al que se encomienda el viajero en un difícil trance también sugiere que éste era el dios principal en su tierra de origen. Lacubegi, así, parece un «dios mayor».

16 Una observación curiosa es que en la mayoría de las ocasiones el cuarto lunar no se esculpe en su posición creciente ni decreciente real, sino en la que se aprecia durante los eclipses, es decir, posado sobre su base. Asociación de los cultos de luna y toro en relación con la ganadería, el matriarcado y los ritos apotropaicos en Blázquez, 1975: 67 y Sayas, 1994a: 235. sustituto sagrado de la divinidad. Sobre la amplitud y el carácter del culto celeste en la Hispania antigua hablan los amenazadores cánones de los concilios XII y XVI de Toledo, de 681 y 693 d.C. (Vives, 1963: 398 y 498), que prohibían a los adoradores de ídolos «las obras de escultura, ni figura alguna de lo que hay arriba en el cielo, ni de lo de abajo en la tierra. No las adorarás ni les darás culto... al sol y a la luna, y a toda la milicia del cielo...».

En el aspecto material, en la zona debían de criarse, como hoy, excelentes toros. Cabe recordar la cita de un Celtis genitus et ex Hiberis como el escritor Marcial, cuando recuerda los toros (Epigr. IV, 55: iuvencis fortibus curvae) criados por Manlio en las arva (llanuras, sembrados, pero también riberas) de la ciudad de Vativesca ${ }^{17}$. E. Ladrero, al finalizar una ya antigua, breve y muy curiosa reflexión sobre el origen egipcio del culto al toro en la antigua Iberia, a propósito del ara de Sos (Ladrero, 1927: 32-33), apunta unas observaciones etnológicas que me parece de gran interés reproducir aquí, setenta años después: «El toro es el animal tratado con más cariño y respeto (en Navarra), y principalmente entre los ancianos, que le dan la garba con su propia mano... acariciándole... su carne no se comía antiguamente, pues se creía que acarreaba grandes males... Cuando el animal moría, se enterraba en un campo, al que hacía más productivo desde aquel momento...». La consideración como tabú de la carne del toro, como también la creencia en su papel fecundador ${ }^{18}$, unidas al trato afectuoso hacia el animal, todo lo cual era aún perceptible entre los vie-

17 El nombre debió ser considerado por Tovar como microtopónimo, porque no lo recoge. Sí Vatinum, según el P. Fita topónimo en la zona de Ariza. La terminación -vesca recuerda otras de ciudades, como la autrigona Virovesca (Tovar, 1989: C-425, que considera el nombre compuesto de celta y $-s c a$, ligur). Creo, pues, que Vativesca puede ser una ciudad celtíbera o celtíbero-vascona, ribereña (¿del Ebro?). Si el elemento Vati-tuviera que ver con vates, los rebaños de toros que Manlio criaba podían ser sagrados (y ¿qué otra cosa podían ser?).

${ }_{18}$ Que no es lo mismo que «genésico». Aquí no comparto la hipótesis de A. Blanco, seguida por J.E. Uranga (1966: 228 y 229) y J.M. Blázquez (1983: 247-254) de que el toro fuera un animal sagrado por su poder genésico y vigor físico, es decir, por sí mismo. Pienso que se le tenía por tabú, fecundante o sagrado sólo en la misma medida en que lo era el dios/a lunar al que representaba y del que era trasunto. Y ello creo que puede valer desde los toros de Creta (donde los frecuentísimos llamados «altares de la consagración»o «de cuernos» debían representar exactamente la misma duplicidad religiosa y ritual) hasta los prehistóricos hispanos de El Oficio y La Encantada, los de Costig o los de la Navarra Media que ahora tratamos (parecida idea, dubitativo, en Sayas, 1994a: 235). La larga serie de leyendas que reúne J. M. Blázquez (loc. cit.) a nombre de A. Álvarez de Miranda, apuntan efectivamente a los valores genesíacos y viriles del toro. Pero repárese en que son todas medievales, modernas y contemporáneas, y en que ha desaparecido completamente 
jos campesinos navarros del primer cuarto de este siglo, parecen guardar para nosotros aún el eco muy lejano del tiempo en que además era entre ellos, y de forma creo que más especial que para otros pueblos hispánicos, un animal benefactor y objeto de culto. De ahí que encuentre adecuado (incluso sin recurrir a los sanfermines de hoy) el término que aquí he utilizado para esta región: Tierra del Toro.

Hay que recordar ahora que la mayor concentración de aras taurobólicas (fig. 1) se da en el área de Sos, Mamillas, Sofuentes, Farasdués y Layana-Sádaba, para tener presente de inmediato a Pascual Madoz (1849: t. IV, 23), cuando hablaba de «las grandes vacadas que dan muy buenos toros para las plazas», que pastaban entonces (como seguramente mucho antes aún) en las llamadas «Bárdenas de Sádaba». Inmediata a ellas (y más en la Antigüedad, $c f$. infra n. 19), en lo alto, está Ujué, que podía ser el centro o uno de los centros del culto al dios lunar y taurófilo. La privilegiada situación de Ujué hace de él el municipio más elevado de toda la Navarra Media (815 m.), y el de término más extenso, avanzada serrana y privilegiado emplazamiento defensivo y de refugio del piedemonte y La Ribera, al decir de S. Mensúa (1960: 143). Este mismo autor refiere la creencia popular de que Ujué fue antiguamente el centro de una comarca densamente poblada, que extendía su influencia hacia las sierras (San Martín de Unx, Lerga, Eslava, Gallipienzo, todos ellos con restos arqueológicos, epigráficos y puntos de calzada) y hacia el piedemonte, llegando a Beire y Pitillas, y considera, entre otros factores, que la abundancia de despoblados en su entorno habla en favor de ello ${ }^{19}$. Podemos añadir, además, la documentación epigráfica de la ermita de Santa Cruz, al SO del vecino San Martín de Unx, pero más cercana al pie de Ujué, donde la misma dedicante ofrece votos por la salud a dos divinidades como Cibeles y el Sol Invicto (Castillo et al., 1981: núms. 30 y 31). Todo ello junto invita a sospechar que también en la Antigüedad Ujué era un posible centro cultual y religioso.

en ellas el referente lunar. Y es que, después de los terribles cánones citados, y de los castigos que se prometían, se ve que la Iglesia debió conseguir desviar al pueblo de la adoración a los astros mediante el toro; pero el pueblo, resistente, la derivó hacia los derroteros de sus también obvias fuerza y virilidad, pasando, entonces sí, a partir de la Edad Media, a ser el toro temido o reverenciado por sí mismo.

19 Según una leyenda muy antigua, el núcleo de población primitivo se encontraba en Santa María la Blanca, donde hoy existe una ermita de esta advocación, poco más de $5 \mathrm{Km}$ al Occidente del actual y más cerca del río Aragón (R. Ciérbide en: Tafalla, 1990, 36). Ahí debía estar cuando al-Himyari hablaba de la «fortaleza de Santamariyya sobre el río Aragûn» (Terés, 1986: 65). El portal de acceso a esta iglesia, del siglo XIII, conserva maravillosamente los relieves con todo el repertorio astral.
La vecina localidad de Tafalla, desde donde los tafalleses peregrinan cada año hasta Ujué, pudo haber llevado el nombre de Curnonion (v. infra, parte II de este trabajo) ${ }^{20}$. No está de más recordar ahora los nuevos cognomina del epígrafe de Pueyo: Cornutus, Cornutinus, que parecen tener también cierta relación con el notable culto al toro que en el área se documenta. Cornu, cuerno, se dice también para referirse a los de la luna. De esta forma, el toro y la luna, ambos bajo la fórmula iconográfica de los cuernos, están tan presentes, como hemos visto, en la decoración de muchas estelas navarras. Pero es más, en dos ocasiones es posible asociar a Júpiter directamente con el culto del toro en la región: En la bella ara de Aibar (Castillo et al., 1981, n 17 , lám. XVII), dedicada Iovi y en cuyo frontón se representa una cabeza de toro, y en el mismo santuario de Ujué, en el que las dos aras parejas ya citadas, que tres Coelii dedican, lo son una a Júpiter y la otra a Lacubegi, llevando ésta (fig. 7) en el lateral esculpida una cabeza de toro (ibid., núms. 33 y 34). No parece difícil pensar que éste es el dios vascón asimilable a Júpiter (así ya B. Taracena y J.E.' Uranga) y de ahí la relación del toro con Júpiter que, de todas formas, es constante en las religiones clásicas. También en este caso, de asombrosa pervivencia ${ }^{21}$ resulta, entre otros ejemplos, el canecillo románico del monasterio de Irache, del siglo xII, con una cabeza de toro y símbolo astral en la testuz (señalado y reproducido por J. E. Uranga, 1966: lám. XVIII, aquí fig. $\left.3, n^{\circ} 9\right)^{22}$.

Atendiendo, por tanto, a la posibilidad de que las aras de Farasdués se orientaran hacia Ujué, y de que en «Sierra de Luna» $y$ «Luna» pudiéramos tener topónimos de frontera, cómo no recordar entonces, retrocediendo mucho más atrás en el tiempo, la estela protohistórica aparecida en este último término ${ }^{23}$, que podría marcar, en mi opinión, el límite

${ }^{20}$ Curnonion es un nombre indoeuropeo que recuerda a Keraunios, uno de los epítetos de Zeus-Júpiter. $C f$. Porfir. v.P.17: Zeus Kretagenés, bajo la forma de un betilo de cuerno.

${ }^{21}$ No puede ser casualidad que Pamplona y toda la comunidad foral sean escenario anual de un verdadero culto popular a los toros.

${ }^{22}$ J. Gómez Pantoja, 1994: 371-376, llama también la atención con acierto sobre las pervivencias de varios motivos iconográficos antiguos navarros y alaveses, entre ellos los alusivos a la luna, en los blasones solariegos modernos.

${ }^{23}$ G. Fatás, 1975: 165 ss., siglo VII a.C.; para la procedencia real de Luna y no de Valpalmas, el mismo autor, $c f$. MM 18, 1977: 234 con n. 9. J. Lostal Pros (1980: 66) sólo dice de ella que está en el paso de unión del valle del Gállego con las Cinco Villas, y que ha sido mal reducida a Gallicolis, quizá por Gallicum, más bien hacia Zuera. Curiosamente, Ceán-Bermúdez (1832: 149) conservaba la tradición antigua de que el lugar se llamó Gallicolis «y pertenecía a la Celtiberia». 
prerromano, por el otro lado de la Sierra de Luna, hacia el territorio indoeuropeo, celtíbero e ilergete ${ }^{24}$. Prefiero, naturalmente, darle a la estela un valor funcional fronterizo y no funerario ${ }^{25}$. Esto supone admitir la «expansión vascona» preimperial que sugirió hace años G. Fatás (1972: 383 ss.), aunque quizá algo más hacia el Oeste que lo que él propone, el río Gállego (fig. pág. 386): Sería más bien, sin llegar al Gállego, desde los Montes de Castejón, por Erla ${ }^{26}$ y las Sierras de Luna y Luesia hacia el Norte, y siguiendo por la Sierra de los Dos Ríos hacia los valles de Ansó o de Hecho ${ }^{27}$. Aunque la citada expansión se atribuye a causas políticas, de alianzas y reconocimiento de servicios por Roma, sin todo ello ya tendría una buena justificación de fondo: Los delimitadores debieron de acabar utilizando las más viejas fronteras. Acaso las que ya eran vasconas en el siglo vil a.C., antes aún de ser celtíberas ${ }^{28}$. Y quizá pudiera encontrar entonces mejor explicación ese instrumento musical, la ciertamente espléndida lira que, junto al escudo escotado, campa en la estela de Luna..

No en balde los geógrafos consideran que la actual divisoria entre Navarra y Zaragoza es puramente artificial: «Las tierras de allende la frontera navarra son una continuación morfológica, climática y humana de la Navarra Media. La Valdoncella y el sector septentrional de las Cinco Villas constituyen

\footnotetext{
${ }^{24}$ Precisamente el detalle de la orientación del ara apuntaría a tratarse aún de zona vascona.

${ }_{25}$ En prensa la tesis doctoral de S. Celestino, véase el estudio más reciente de E. Galán Domingo (1993), con toda la bibliografía y opiniones anteriores. Aunque admite aún (77 ss.) que puedan haber tenido también un significado funerario (lo que, desde su óptica, parece innecesario), sostiene su función principal como marcadores territoriales en relación con élites «atlánticas», y con las redes terrestres de paso y comercio, todo ello antes del comienzo del proceso colonial, hacia el siglo VIII a.C. No puedo entrar ahora en tan espinosa cuestión, que explaya la tesis previamente defendida por M. Ruiz-Gálvez y él mismo (1991: 257 ss., espec. 269-273), pero la de Luna y otros casos, que están lo suficientemente lejos del «hinterland tartésico», tienden a hacer preferir nudamente la función delimitadora de territorios por muy determinados pueblos. La perfectamente dibujada lira de la estela de Luna, por otra parte y precisamente, se escapa a mi juicio de cualquier interpretación economicista.

26 Véase otro argumento infra, parte II, bajo el $n^{\circ} 14$

27 Por aquí transcurría la via famosa de que habla CIL II, 4911, de Hecho (HU.), aunque conservada en San Pedro de Siresa, en su camino hacia Somport.

28 Aquí quisiera recordar una antigua hipótesis, de 1951, de M. Gómez Moreno, traída a colación elogiosamente por A. Tovar (1989: 55). Gómez Moreno sugirió que, quizá a comienzos del I milenio a.C., un movimiento de cántabros aledaños habría atravesado el Bidasoa y los Pirineos; después de él, se produjo el empuje inverso, entrando celtas por Cataluña y por el extremo occidental pirenaico, que desplazaron a su vez a iberos y vascones hacia el territorio de várdulos y autrigones.
}

una réplica aragonesa de nuestra región...» (Mensúa, 1960: 13). Así, posiblemente los agrimensores romanos, reconociendo varios siglos después esta realidad étnica y geoeconómica, se limitaron nada más a restablecerla.

\section{ENSAYO DE IDENTIFICACIÓN DE CIUDADES VASCONAS}

La Guía Geográfica (Geographikè Ùphégesis) de Ptolomeo ${ }^{29}$ tiene indudables dificultades de comprensión en las que no es el caso ahora entrar ${ }^{30} \mathrm{y}$ que han sido objeto secular de estudio y polémica en y después de la Antigüedad, y sobre todo a partir de los astrónomos y geógrafos árabes. Como muestra acerca de sus problemas de precisión en el entorno que aquí vamos a considerar, baste decir que, aunque su orientación es buena, calcula para la longitud total del río Ebro 2500 estadios, es decir, unos $450 \mathrm{Km}$, y por tanto casi $300 \mathrm{Km}$ menos de los 720 que en realidad tiene ${ }^{31}$. Acaso más ilustrativo aún sea decir que, para establecer las coordenadas de sus quince ciudades vasconas del interior de cuya localización voy a tratar, Ptolomeo utiliza 2 grados de latitud N-S, cuando lo real es 1 grado y $20 \mathrm{mi}-$ nutos, y que para la longitud E-O abarca 1 grado y 10 minutos, habiendo 1 en la realidad. Ni siquiera, pues, existe proporcionalidad en su descripción.

$Y$ es que, por razones diversas, su exactitud dentro de su tratamiento de Hispania, como para otras zonas del ecumene, es irregular. Tales dificultades, sin embargo, no deben desanimar completamente para un beneficioso aprovechamiento de sus valiosos datos, sino que hay que recurrir a combinar otra serie de informaciones y puntos de vista, que es lo que aquí trato de ensayar, explorando alguna ruta inédita en la investigación con el ánimo de ofrecer hipótesis nuevas, aunque sean discutibles y polémicas, o incluso aunque no se demuestren todas acertadas con el tiempo, ante el hecho de que, siendo copiosísima la bibliografía dedicada al territorio

${ }^{29}$ He utilizado directamente las ediciones de S. Münster $(1540=1966$ : cap. 6,66$)$, C.F.A. Nobbe $(1881$ : cap. 6,67$)$ y la soberbia del msc. de la Universidad de Valencia (Códice Valencia: 1983). La de K. Müller $(6,66)$ sólo a través de la reciente del fasc. VII de los FHA (Barcelona, 1987) que, sin embargo, en este capítulo (págs. 94 y 197) contiene algunos errores en las cifras.

${ }^{30}$ Serán objeto de un estudio más amplio. Algunos de los problemas al respecto son bien tratados por V. Navarro Brotóns en la introducción a la espléndida edición del códice ptolemaico de la Universidad de Valencia (Valencia, 1983 24 ss.). No he podido utilizar la monografía de F. Cordano, La geografia degli antichi, Bari 1992.

31 Cf. sobre ello Schulten, 1963: 28 
vascón de época romana, continúan muchas de sus ciudades sin reducciones claras, siendo habitualmente los a veces escurridizos parecidos toponímicos, y no los repertorios geográficos antiguos, los que más se han usado al sugerir ubicaciones para la mayor parte de ellas.

Ptolomeo dedica a las ciudades de los vascones el capítulo 6, 66 de su libro II, mencionando 15 de sus ciudades interiores, más la marítima Oiassó, con sus coordenadas. De ellas están bien identificadas (la mayoría desde hace siglos) Pompailón, Andelo, Gracourís, Kalagorína, Káskonton ${ }^{32}$, Ségia ${ }^{33}$ y Alauó$n a^{34}$ (respectivamente con Pamplona, Muruzábal de Andión, Alfaro-Corella, Calahorra, Cascante, Ejea de los Caballeros y Alagón), por lo que no son ahora objeto de nuestro interés más que para usarlas como puntos sólidos en torno a los cuales poder movernos. Para las restantes nueve (Oiassó, Etoúrisa, Bitourís, Nemeturissa, Kournónion, Iska ${ }^{35}$, Ergaouí(k)a, Tárraga y Mouskaría) se vienen barajando varias posibilidades sin confirmación epigráfica; entre ellas, sólo Oiassó, gracias a la homonimia y la arquelogía, cuenta con más y mejores hipótesis de localización. Creo también, como cuestión previa, que un prejuicio muy general al hacer idénticas la Iákka ptolemaica y la Jaca oscense ha impedido un mejor aprovechamiento del geógrafo; pues si se acepta la ubicación según la da Ptolomeo, literalmente al sur de Ándelo y Etúrissa, nos resulta un factor que duplica la ya compleja distorsión de los datos del geógrafo. Hay, por tanto, que deshacer — sin tajarlo- ese verdadero nudo para poder liberar los demás datos.

Primero ubicaremos los puntos de las ciudades mencionadas sobre una simple rejilla (fig. 8) y según las coordenadas antiguas, y prescindiremos ahora de la cuestión astronómica y de muchos otros problemas de la crítica ptolemaica. Sí tendremos en cuenta,

32 Ésta con menos unanimidad, puesto que varios manuscritos la llaman Básconton (así en la de 1540 de S. Münster, 1966: 15).

${ }^{33}$ Los msc. ptolemaicos aquí siempre dan Sétia. Es curioso anotar que también para la Segida Restituta Iulia betúrica (Ptol. II, 4, 10) varias versiones dan Sétida, también con T.

34 Como se ha recordado recientemente (M. Beltrán, en: Arqueología, 1992, 203-204), no se conocen hasta ahora prácticamente en su término hallazgos antiguos, salvo el interesante tesoro de denarios ibéricos (A. Beltrán, ibid.: 157 ss.), aparecido en 1970 en el lugar llamado «La Codera de Alagón», que incluía, entre otros, 30 de Baskunes/Bencoda, 26 de Arsaos, 14 de Turiasu y 25 de Arekorata, posiblemente posteriores al 72 a.C. (ibid.). Se trataba de una escombrera de remociones de tierra de la próxima base aérea militar. Pero, aparte de la homonimia, le conviene al sitio el contexto de su mención en la tabula Contrebiensis.

35 Utilizo ya aquí, en vez de I/Turissa, Nemantourista y Iakka, los que creo fueron sus nombres reales. Más abajo, en su correspondiente apartado, se explica con detalle.

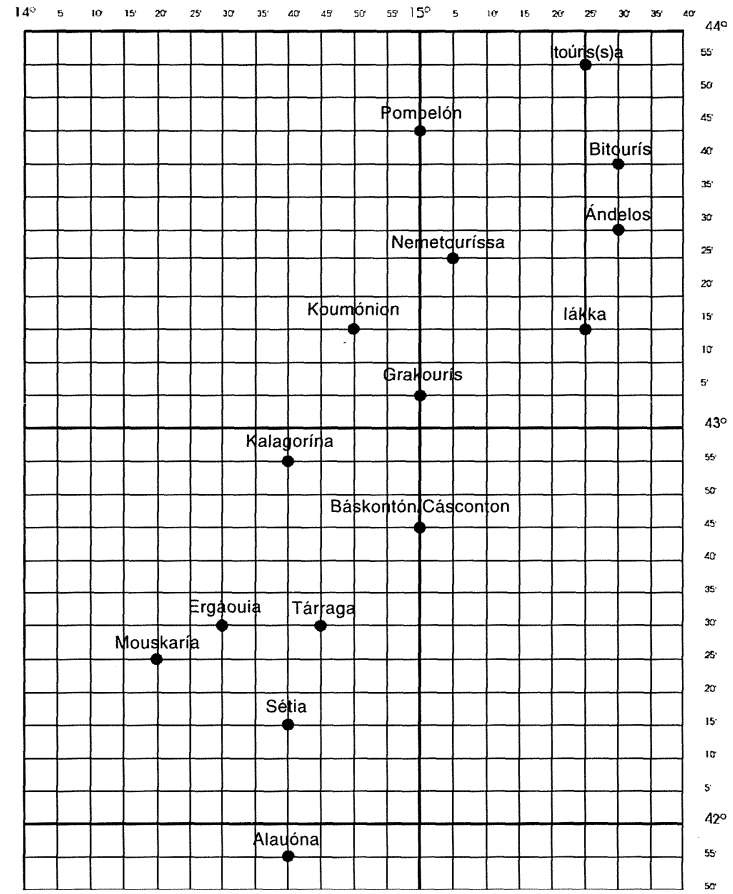

Fig. 8.-Ubicación de las ciudades vasconas interiores, según las coordenadas de Ptolomeo II, 6, 66, sobre una rejilla simple.

por ejemplo, la apreciación más vertical de los Pirineos que se mantuvo en los geógrafos antiguos y medievales. Y también que, para zonas alejadas o no muy conocidas, Ptolomeo, a pesar de su rigurosa defensa teórica de la superioridad de la coordenación astronómica sobre la medición de distancias terrestres, para lugares poco conocidos tuvo necesidad de servirse finalmente de otras fuentes, itinerarias y corográficas (Códice Valencia, 1993: 25), por lo que no podemos esperar un completo rigor. Admitiendo lo anterior, se podrá apreciar entonces, en la rejilla, que existen unas orientaciones generales que -y ésta es la novedad de su análisis que propongo- pueden ser relativamente válidas estudiadas y entendidas por conjuntos relativos y no globalmente como se viene haciendo. En la fig. 9 muestro la hipótesis ${ }^{36}$.

Por ejemplo, partiendo de Pompaelo como punto más seguro, (E/I)turissa está al N-NE y, en la vertical de Pamplona, Cascantum. Por otro lado, al SE real se encuentra Segia (Ejea de los Caballeros), con Alauona (Alagón) al S, casi en la vertical de Segia. Estas ubicaciones sí son más o menos coincidentes en la realidad con las coordenadas en las

36 Agradezco al alumno de Arquitectura de Madrid D. A. Rubio Valenzuela el haberme auxiliado en el tratamiento digital de las figs. 3, 8, 9, 11 y 12 . 


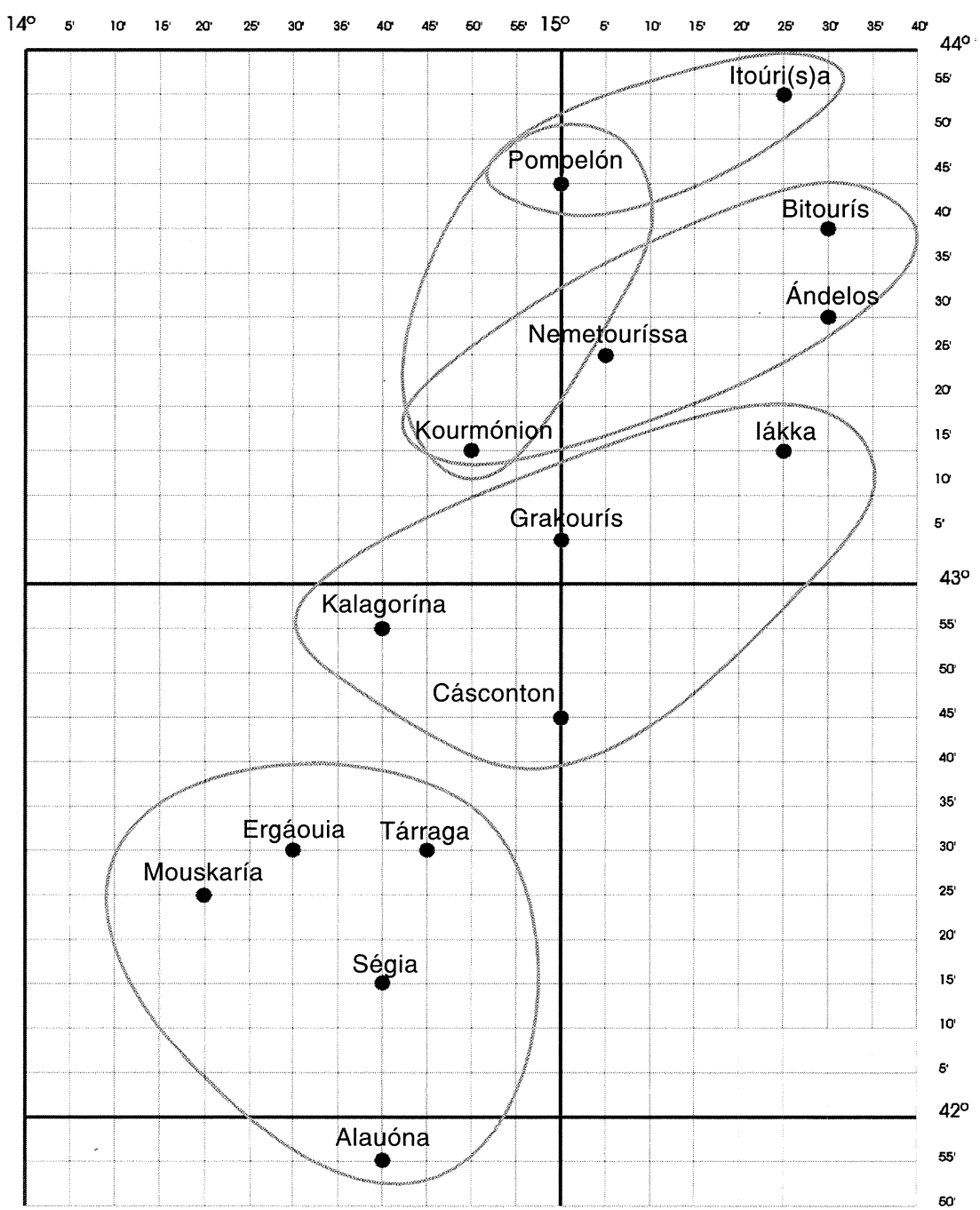

Fig. 9.-Propuesta de análisis sectorial de las ciudades vasconas transmitidas por Ptolomeo II, 6, 66.

que las dispone Ptolomeo (aunque no, como ya he dicho, con las distancias reales), si bien el grupo más meridional se encuentra, en bloque, claramente desplazado y, por tanto, debe buscársele acomodo a todo él en la mitad derecha de la rejilla, ya que $\mathrm{Se}$ gia y Alauona están, lo mismo solas que entre ellas, correctamente localizadas. Asegurado así el $\mathrm{N}$ y el $\mathrm{S}$ del territorio ptolemaico, el valle del Cidacos cae en ese caso entre Pompaelo y Cascantum, como en realidad ocurre, y entre ambos núcleos conocidos tendríamos tres nombres de ciudades desconocidas: Nemeturissa, Curnónion y Iákka ${ }^{37}$. El Anónimo de

${ }^{37}$ Como se avanzó, la identificación habitual de esta Iákka con la Jaca oscense me parece descartable. Los Iaceta$n i$ aparecen siempre en las fuentes (por ejemplo en Estrabón III, 4, 10) muy bien separados de los otros pueblos del valle
Rávena (312, 1-3) menciona otras tres más que están super scriptam civitatem Gracuse: Beldalin, Erguti y Beturri, las tres ignotas. El mismo autor, sin embargo, refiere otras cinco ciudades vasconas en su citadísimo párrafo 311, 10-14: (... iuxta super scriptam Caesaraugustam...:) Seglam, Teracha, Carta, Pompelone, Iturisa. Y como estas cinco están citadas desde el Sur hacia el Norte, creo legítimo suponer que lo mismo ocurre con las tres anteriores.

Beturri sólo puede identificarse con la Bitourís ptolemaica, entre Pompaelo y Andelo, con lo que Beldalin y Erguti deben buscarse asimismo entre

del Ebro. Debe optarse (de momento) por la duplicidad, y sólo aparente, como se verá más abajo. 
«Gracuse» (Gracchurris, c. Alfaro) y Pamplona. Por tanto, con respecto a Gracuse/Gracchurris ${ }^{38}$, al sur, debemos buscar, por este orden, que BeturriBitouris esté más al N, más abajo de ella Erguti y al Sur, pero sin llegar al Ebro, Beldalin. Las tres deberán estar además al $\mathrm{O}$ del río Cidacos ${ }^{39}$, donde está Curnonion, por el hecho de que Bitourís sabemos que está sobre Andelo y ésta, conocida y excavada, se encuentra en realidad al SO de Pamplona y no al SE como Ptolomeo nos la presentaba. De ahí que debamos desplazar todo este sector, excepto Kournónion ( $c f$. infra), a la zona izquierda de la rejilla, con lo que Nemeturissa seguirá estando al O de Andelo pero más o menos entre los valles de los ríos Ega y Arga, con Kournónion en su lado SE. Así pues, este grupo de modificaciones depende de dos cosas: De que conocemos con certeza la posición de Andelo, y de que Beturri (Bitourís) debe hallarse al N de Gracuse, según el Anónimo de Rávena.

Además de estas ciudades de ubicación incierta, también el Ravenate $(311,11)$, entre las ciudades que están «sobre Zaragoza», cita una, Teracha, no bien reconocida pero que unánimemente, por el lugar (calzada entre dos ciudades bien conocidas: Ségia y Cara) y por la similitud, se identifica con la Tarrega de Ptolomeo ${ }^{40}$. Y, por último, recurrimos a la numismática: Una ceca considerada navarra, y asimismo sin ubicar, es la de Olcairun/dun ${ }^{41}$ (Castiella Rodríguez, 1989: 678 con n. 8). Añadamos ahora la citada ceca de Bascunes, la más importante por el número de hallazgos; la mayor concentra-

${ }^{38} \mathrm{El}$ que en los msc. falte la mención previa de Gracuse sólo significa lapso, o que se han perdido algunas partes del texto, pero ello no resta ninguna validez a esta indicación. Gracchurris es la más antigua colonia latina en el valle del Ebro (179 a.C.), fundada seguramente en función del hierro vascón (Canto, e.p.) y es obvio que en época del Ravenate debía mantener aún su prestigio como ciudad importante en la red viaria.

${ }^{39}$ Hay dos ríos del mismo nombre, casi afrontados. Me refiero aquí, naturalmente, al de la margen izquierda del Ebro, que baja desde el Norte bañando Tafalla y Olite.

${ }^{40}$ Aunque varios autores antiguos la pusieron, por el simple parecido, en Larraga, a pesar de la distancia a Ejea y Santacara, la Teracha del Ravenate, Tarrega pliniana, antes citada, tiene muchas probabilidades de situarse, como se ha sugerido desde hace mucho, en la zona de Sádaba, o incluso, como ya dije, en Farasdués, a juzgar por las coordenadas que le asigna Ptolomeo, al NE. de Segia/Ejea. Pero como el territorio, ya lo vimos, está además girado ligeramente hacia el Este, puede incluso estar al NO de ella, como de verdad lo está Sádaba, $c f$. infra.

${ }^{41}$ Supongo que la ceca de Olcairom es la misma que Guadán (1969: 199) y Aldecoa (1965) estudian como Olcairdun Olcairun, en el subgrupo que llaman «centro-aragonés». Más recientemente, A. Beltrán (1987: 342-343) la lee Okikaurun, ubicándola «en la Navarra Central, alejada del valle del Ebro»; $c f$., en las Actas del mismo congreso, Labe Valenzuela: 450 . ción de ejemplares con procedencia se da en Tafalla (Castiella Rodríguez, 1986: 149-150 con n. 33) y en el tesorillo de Alagón (Arqueología, 1992: 157 ss.). Como para ambas ciudades existe posibilidad de otros nombres antiguos, se puede concluir al menos que Bascunes deberá estar en todo caso cercana a ambas. La importante y fronteriza ciudad de Tudela parece ambas cosas sólo en la Edad Media, no se tiene por romana a pesar de su nombre, y merecerá también un detallado análisis.

Al final de esta cosecha, nos encontramos con la posibilidad, sólo entre Ptolomeo y el Ravenate, de la existencia de al menos doce ciudades ${ }^{42}$ sin ubicar en la zona central del ager Vasconum, en el entorno del valle del Cidacos y, en general, en la Navarra Media, entrando por el Oeste en la actual provincia de Zaragoza, entre las líneas de Pamplona por el norte y el río Ebro por el sur: Eturissa, Bituris/Beturri, Nemeturissa, Curnonion, Iaca, Ergavica/Erguti, Beldalin, Tarraga, Muscaria, Olca; además pueden sumarse Tudela (una posible Tutela), Bascunes y, si se quiere, el solar de la única gentilidad (aparentemente) documentada, los $\mathrm{Ta}$ laiari. En el caso de Oiarso se volverá sobre su últimamente negada duplicidad. Y veremos la posibilidad de ubicar también algunas otras ciudades vasconas del saltus, que conocemos por fuentes posteriores, como Ispallum o Seburi. Otras como Illuersia, Seraria(na) o Aracaeli, se mencionarán sólo de paso. Diecisiete ciudades, pues, serán objeto aquí de nuestra atención. La exuberancia urbana en la Navarra Media se corresponde con la feracidad del terreno y el alto nivel de ocupación rústica antigua y actual. Naturalmente, no es el propósito de este trabajo efectuar toda una serie de hipótesis para cada una de ellas, puesto que mi conocimiento del territorio sólo puede calificarse de modesto. Serán la epigrafía y, en menor medida, la numismática, las que vengan en los próximos años a concretarlo. Pero sí haré un ensayo, a partir de algunas fuentes literarias, las calzadas, los miliarios y los restos arqueológicos.

Parto de la base de que tanto Ptolomeo como el Ravenate citan ciudades de alguna relevancia (y no todas, esto también es seguro). Y que, por tanto, éstas deberían estar unidas entre sí por calzadas. Los miliarios (fig. 10), pues, pueden tomarse como indicativos, no sólo de viarios, sino también de la

${ }^{42}$ Se observará que no he acudido a sumar otras cecas monetales sin patria del llamado «grupo pirenaico», e incluso otras ciudades que cita Plinio de este mismo convento, como la usualmente olvidada segunda Calagurris, la de los Fibularenses, porque prefiero ceñirme a lo que puede ser considerado territorialmente «vascón». 


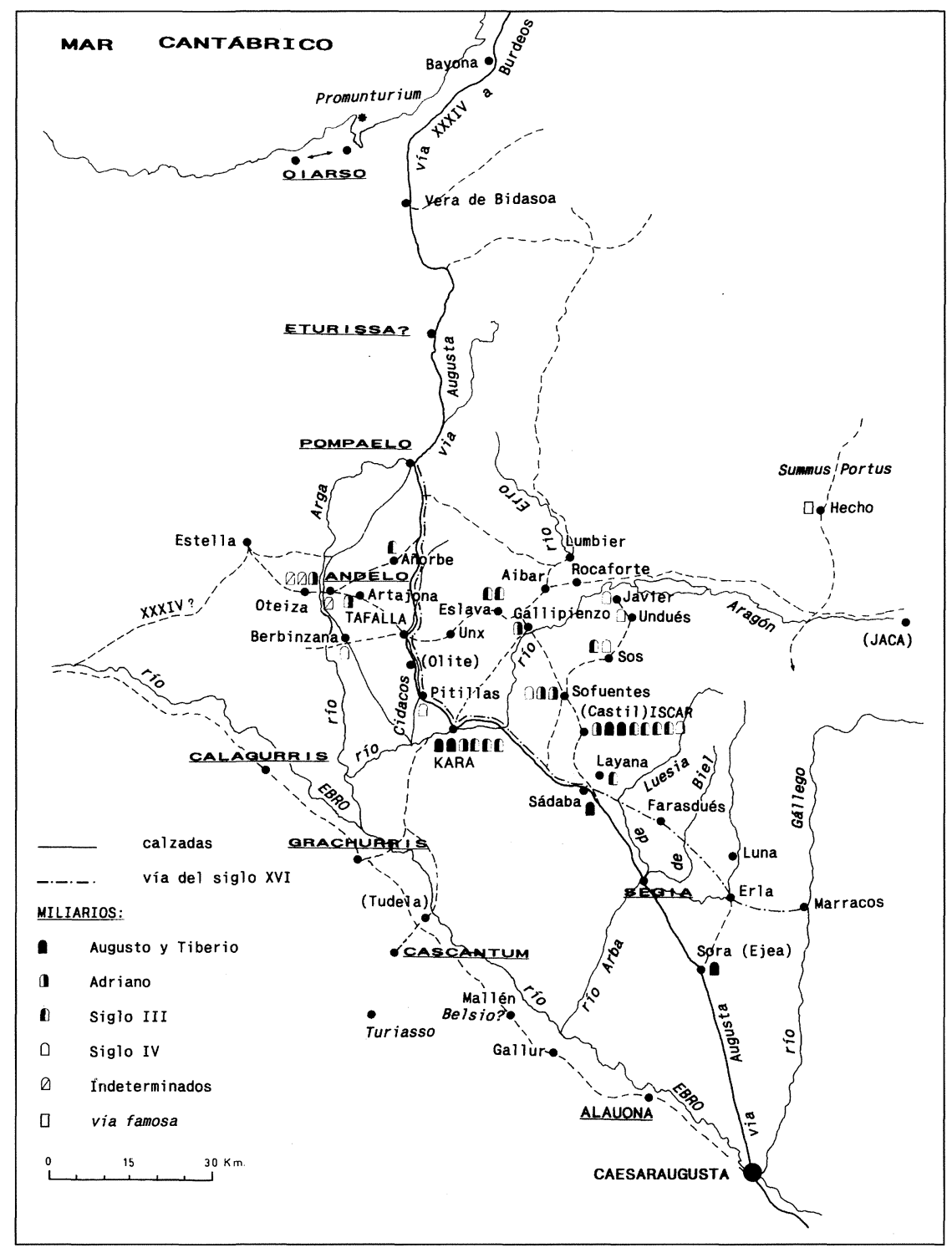

Fig. 10.-Distribución de los miliarios en el territorio del ager Vasconum y red hipotética de las calzadas a partir de ellos (mapa de A. Canto y S. Luzón).

proximidad de ciudades, especialmente cuando aparecen cerca de yacimientos antiguos con restos diversos y con epigrafía, especialmente votiva ${ }^{43}$. Y, como veremos al final de este trabajo, también la ausencia completa de todos esos tipos de testimonios puede llegar a ser muy significativa.

Combinando todos los criterios dichos (más la toponimia, que usaré más adelante), tienen opción a estos nombres antiguos, de $\mathrm{E}$ a $\mathrm{O}$, los actuales mu-

43 Puesto que la funeraria, de no detectarse las necrópolis urbanas, puede corresponder a cementerios de fundos privados. nicipios de Farasdués, Layana-Sádaba, Tudela, Castiliscar, Sofuentes-Sos, Eslava, Olite, Tafalla, Artajona, Berbinzana, Oteiza-San Tirso, deteniéndonos en la línea de Estella, y, al Norte, Oyarzun-Irún ${ }^{44}$. Comenzaré desde el Norte, siguiendo a Ptolomeo.

${ }^{44}$ Como se ve, afectan a al menos tres Comunidades Autónomas y provincias actuales. Vengo defendiendo hace mucho tiempo que la investigación de la España Antigua hubiera avanzado más si no hubieran proliferado tanto los estudios limitados a marcos provinciales en exceso modernos. El objeto de estudio debería siempre corresponderse, especialmente para la época romana, con ciudades, regiones, y unidades étnicas, geográficas o conventuales, antiguas. 
En esta parte citaré especialmente la obra de A. Tovar (1989), puesto que recoge las fuentes antiguas y localizaciones de cada topónimo, aunque debe seguirse también, para complementar algunos aspectos de hallazgos arqueológicos, o de ausencia en su caso, la monografía de $\mathrm{M}^{\mathrm{a}} \mathrm{J}$. Peréx Agorreta de 1986, s.vv. Al final se encontrará el mapa con la distribución hipotética de estas quince ciudades, donde he añadido otras que no trato con más detalle, como Illuersia, Aracaeli o el posible solar de los Talaiari (la única gentilidad documentada, posiblemente no vascona) y una sí bastante elaborada hipótesis sobre el carácter de las Bárdenas Reales en época romana.

\section{1) Oiassó, Oiarso = Oyarzun e Irún}

Con la segunda grafía, la pliniana (III, 4, 29 y IV, 34, 110), viene ubicándose en Oyarzun (Guipúzcoa) por el parecido toponímico. Éste es evidente y no discutible (Tovar, 1989: C-505; Peréx, 1986: 180), pero creo que no tiene que limitarse a él. Porque, en efecto, Estrabón dice (III, 4, 10) que «está alzada en el borde del océano», pero Plinio, respectivamente (ibid.), habla del litus Oiarsonis, «la costa» de la ciudad, y de su ubicación sobre el Océano, y ello se corresponde bien con las dos mediciones diversas que da Ptolomeo (II, 6, 10): Por un lado la ciudad de Oiassó y, por otro, «el promontorio de Oiassó del Pirineo». Como prosigue en su parágrafo 11 , desde este promontorio comienzan los Pirineos. Parece, puesto que la ciudad y el valle de Oyarzun actualmente quedan demasiado al interior, que «la costa de Oyarzun» debe considerarse la zona de Irún-Kosta ${ }^{45}$, y el promontorio mismo el relevante cabo Higuer, con un Veneris iugum según Avieno (Schulten, 1958: 35) ${ }^{46}$. Se abriría así, más

\footnotetext{
45 Otros autores que diferencian los dos núcleos han preferido ver en la zona de Pasajes la litoral y en el monte Jaizkibel el promontorio (Peréx Agorreta, 1986: 182 con las referencias).

46 La referencia a este templum Veneris del Pirineo atlántico, aunque se ha discutido, ignorado, o atribuído al templo de Venus de Port Vendres, en el Pirineo mediterráneo, puede ser cierta, ya que tiene lógica que en ambos extremos de la cordillera hubiera un templo a la misma diosa y, además, elIdrisi (1974: 74) incluye las ciudades de Çoly, Tudela, Huesca, Jaca y Calahorra en lo que llama «País del Templo», y me parece muy lejos para que su referente sea el del Mediterráneo (pace E. Saavedra, ibid.: 151 , a pesar de que Idris está describiendo aquí sólo el norte de España). Fernández Ochoa y Morillo (1994: 145) citan el hallazgo reciente de un lote de bronces romanos, incluso de tipo religioso (apliques con Marte, Minerva, Sol y Luna) hallados en el mismo fondeadero de Cabo Higuer, pero no los relacionan con Avieno, ni se refieren al templo.
}

que un punto, un abanico costero para los vascones. Importa el detalle también a la hora de considerar una alternativa al Summus Pyrenaeus vascón mencionado por el Itinerario de Antonino en la vía XXXIV, como veremos más abajo.

Se han agrupado recientemente los testimonios arqueológicos de la zona, apostando por la ubicación de la antigua Oiassó sólo en el cerro de Beraun, de Irún, al fondo de la bahía de Fuenterrabía (Fernández Ochoa-Morillo Cerdán, 1994: 147 ss.), con al menos dos muelles a su pie y una cronología de comienzo fluctuante entre el último cuarto del siglo I a.C. y el cambio de era o poco después (ibid.: 151, ahora Unzueta, 1996: 166). Sin embargo, Peréx Agorreta (1986: 183) ya anotaba la existencia de indicios de población dispersa entre Oyarzun y Fuenterrabía e Irún. Y es de recordar también una menos citada frase del Ravenate (318, 1-3): Item iuxta superius nominatam civitatem Ossaron, quae ponitur non longe ab Oceano..., que insiste en la idea del doble núcleo, ciudad y puerto. Por tanto, la potenciación del puerto de Irún por los romanos, al menos a partir de la construcción de la calzada desde Tarraco, en la última década del siglo I a.C. (para el movimiento del mineral extraído en la región inmediata de Arditurri o para relaciones comerciales genéricas), debió a la vez de mantener el núcleo urbano interior vascón ${ }^{47}$, que seguiría desarrollándose en el área de Oyarzun y el río Bidasoa, más próximo a las explotaciones mineras, una actividad sí específica de la época anterior. Creo, pues, que es muy factible defender la posibilidad del doble núcleo urbano para Oiassó (Caro Baroja, 1996: 468).

Los Talaiari. Creo que no se ha señalado aún que en esta costa, limitando por el E la ensenada de Asabaratza, se encuentra un accidente geográfico, una punta, de nombre «Talaiari». La única entidad gentilicia documentada en territorio vascón lo es en un ara votiva, quizá al $D($ eus $)$ M(agnus) P(eremusta?), procedente de Rocaforte (Taracena-Vázquez de Parga, 1947: $\mathrm{n}^{\circ}$ 45a; Castillo et al., 1981: $\mathrm{n}^{\circ}$ 29), dedicada por una $I / T / F e s i n e$ que se dice Talaiorum $^{48}$. Si su zona de origen se correspondiera con

\footnotetext{
$47 \mathrm{O}$ várdulo, según P. Mela, III, 1, 15. No es verosímil pensar que el puerto se creara en época prerromana en función de una navegación de gran calado.

48 Para el nombre se han propuesto también Fesine y Pesine (éste improbable). Recientemente, H. Gimeno y J. Velaza (1994) sugirieron otra lectura para este epígrafe, que lo convertía en funerario: $D$ (iis) $M$ (anibus) P/aesine /[O]tai (filia) ân/orum $/^{l}$ XIII. Sin embargo, una excelente fotografía antigua de J. E. Uranga (publicada por Taracena-Vázquez de Parga, ad loc.), cuando el epígrafe estaba en mucho mejor estado, nos impide aceptar su ingeniosa propuesta de lectura, prefiriendo así la anterior, $D \cdot M \cdot P \cdot$.
} 
este área de la «Punta Talaiari» - y la identidad del nombre parece bien concluyente-, se comprendería la anomalía, in ultimo Vasconum, ya más bien partícipes de los hábitos septentrionales ${ }^{49}$. Me parece, no obstante, más probable que los Talaiari fueran mejor la primera gentilitas costera ${ }^{50}$ de la gens bardieta o várdula, porque además no se documentan gentilidades entre la natio de los vascones. La frontera común debía de ser la ría de Pasajes.

La vía XXXIV. Por último, en relación con esta zona costera vascona, parece que se debe aceptar que una buena calzada debía indefectiblemente unir Oiarso al menos con Pompaelo y de la forma más directa; pero no, o no sólo, porque era la única salida marítima de los vascones (circunstancia que, a los ojos pragmáticos de la administración imperial, sería perfectamente secundaria), sino porque se trata de la gran calzada Tarraco-Oiarso, obra de Augusto (Estrabón III, 4, $10^{51}$, de ahí que pueda utilizarse quizá para ella también la denominación de via Augusta), y cuya calidad y tránsito serían mayores ${ }^{52}$. Según R. Syme (CAH X: 343) allí «se cruzaba con otra de San Sebastián a Bayona», suponiendo que esta otra ruta entre Hispania y Aquitania fue abierta en los momentos iniciales de la guerra cántabra, con Augusto (Tovar, ibid. ${ }^{53}$ ). Habría, por tanto, que contar con que ambas, ya unidas, atravesaban los Pirineos por Behobia-Bayona o incluso por Bidasoa-Ibardín, para encaminarse en una sola hacia Aquitania y Burdeos. Y con que aquí también,

${ }^{49}$ También podría tomarse como indicio de la anterior pertenencia de esta zona a los várdulos («un sólo pueblo que se extiende desde aquí hasta el promontorio de los Pirineos»: P. Mela, ad loc.). La ensenada inmediata hacia el O., delante ya de Pasajes, conserva bien el nombre de «Murgita», ambos nombres indicativos de frontera.

50 Plinio, NH IV, 110: A Pyrenaeum per Oceanum... Olarso, Vardulorum oppida..

${ }_{51}$ «Esta misma región (scil., el valle del Ebro) está cruzada por la vía que parte de Tarraco y va hasta los vascones del borde del océano, a Pompelo y Oiasón, ciudad alzada sobre el mismo Océano... se termina en la frontera entre Aquitania e Iberia».

52 La muy y muy bien estudiada «vía de las Cinco Villas» debía ser sólo un tramo del recorrido general desde Tarragona, a juzgar por los cinco miliarios de Sora de Ejea, Ejea, Sádaba y Castiliscar datados de Augusto y Tiberio. No es propiamente una conexión entre Zaragoza y Pamplona (que también), sino la ruta hispana más corta para enlazar Mediterráneo y Cantábrico y para alcanzar Aquitania. Con moderadas dudas sobre ello Aguarod-Lostal, 1982: 168. Su ausencia en el Itinerario de Antonino no es más que otra prueba del carácter particular e imperfecto de este repertorio tardío. Una vía casi paralela cumplía la misma función en Galia, vía que además era la más corta desde Roma.

53 Aspectos de detalle, con microtoponimia, interesantes en cuanto a las múltiples rutas y pasos viarios en el interior del País Vasco, han sido tratados recientemente por M. Esteban (1990: 75 ss. y 85 ss.). en lógica consecuencia, habría un Summus Pyrenaeus ${ }^{54}$ y un Imus Pyrenaeus. Y esto nos lleva a la siguiente ciudad, ya en la serie del interior.

\section{2) Eturissa, (I)toúris $(s) a=$ ¿Iterrizokoa/Velate?}

Epigráficamente documentado el primero, debe ser el correcto (aunque nada impide aceptar un cambio vocálico, o su pérdida, a lo largo del tiempo). El Itinerario de Antonino $(455,6)$ y el Ravenate $(311$, 14) la mencionan al norte de Pompaelo y Ptolomeo la ubica al NE de ésta misma ${ }^{55}$. La gran mayoría de los autores se han inclinado a identificarla por otra ruta más al E, en la zona de Espinal (Peréx-Unzu, 1987: 555; de Miguel, 1992: 260, entre otros muchos), camino del Puerto de Ibañeta/Roncesvalles, donde se han hecho también hallazgos y excavaciones arqueológicas, pero no concluyentes en cuanto al nombre (Peréx, 1986: 172). Todos estos autores parecen aceptar que esta via Augustea tenía algún motivo para desviarse hacia el Este. En cambio, sobre la ruta hacia Oiassó/Oiarso (a cuya importancia estratégica acabo de referirme y que no debería desde Pamplona más que seguir hacia el estricto Norte) sólo K. Müller supuso Iturissa en Ituren (por cierto algo desviada del camino, Tovar, 1989: C456). G. Arias, otro buen especialista en calzadas antiguas, la ubicó también en ella, poco antes de Almándoz, al señalar restos de pavimentación romana a la altura del Puerto o Alto de Velate (1968: 440; foto en Peréx, 1986: 340).

Conviene advertir que por ninguna de las dos rutas, Espinal o Velate, encuentran acomodo las 40 millas totales (unos 59,2 Km) que indica el Itinerario de Antonino entre Pamplona y el paso de los Pirineos ${ }^{56}$, ni las 18 millas $(26,6 \mathrm{Km})$ de su segun-

${ }^{54}$ Obviamente, entendiendo summus no como el punto absoluto más alto de la cordillera, sino como el más alto de la calzada que la va atravesando. De ahí que en todos los pasos viarios pirenaicos debiera haber postas del mismo o parecido nombre, como el Summus Pyrenaeus (Summus Portus) de la vía oscense a Beneharnum.

55 Recuerdo ahora el problema de la casi verticalidad de los Pirineos en este autor, que «achata» todas sus proporciones en cuanto a las longitudes. Ello hace que no debamos considerar más que una ligera desviación, al NE., de Eturissa con respecto a Pompaelo. Esta observación vale más adelante para otras ciudades.

56 Observación ya hecha por Taracena-Vázquez de Parga (1947: n. 16), indicando que de Pamplona a Ibañeta por Espinal sólo hay $49 \mathrm{Km}$. He encontrado una precoz guía turística (Guía, 1923: 19) que detalla el recorrido y coincide exactamente en estos $49 \mathrm{Km}$. hasta Ibañeta, a Espinal 40, a Valcarlos con el paso, 64 y $74 \mathrm{Km}$ hasta San Jean de Pied de Port, desde donde se podía continuar por carretera o ferrocarril hasta Bayonne. Pero curiosamente, la misma guía (pág. 
do tramo, de Eturissa a Summus Pyrenaeus (sobre ello, de Miguel, ibid.). A la muy relativa fiabilidad general del Itinerario (Roldán, 1975: 22-23) quizá haya sólo que añadir otros errores en esta misma vía ab Asturica Burdicalam (ibid.: 100) para sostener que ha habido en los manuscritos una minoración del número de millas hasta el Summus Pyrenaeus. No hay otros datos de restos arqueológicos, aunque los de la calzada parecen suficientemente indicativos y deben complementarse con la existencia del «puente de la Reparacea», en el camino de Velate a Oyarzun (Liz Guiral, 1985: 71). De otro lado, es en la línea de los puertos de Velate y Azpiroz donde los geógrafos observan la divisoria cantábrica ${ }^{57}$. Poco antes de Velate sí se cumplen aproximadamente los $32,5 \mathrm{Km}$ desde Pompelo a Eturissa. Defiendo esta localización, cerca de Iterrizokoa-Velate, para Eturissa por otras cuatro razones:

La primera, porque, a tenor de lo dicho, la desviación en Ptolomeo de ella con respecto a Pamplona, es exagerada (como ya dije, cabe toda la Vasconia ptolemaica en 1 grado de longitud). La segunda, porque es la que mejor conserva la dirección final de la calzada XXXIV, que es alcanzar, se supone que por el camino más corto, Aquae Tarbellicae o Augustae $\left(\right.$ Dax $\left.^{58}\right)$ y Burdigala (Burdeos) y, si hay alguna ciudad conocida entre Pamplona y Oiarso, es lo lógico que esté en esta ruta: El paso por EspinalIbañeta-Roncesvalles, el antiguo portus Cicereus ${ }^{59}$, con sus 35 millas a través de la cordillera (al-Idrisi,

27) ofrecía a los turistas motorizados de comienzos del siglo una segunda ruta, algo más larga pero bella, que rodeaba por Aoiz y Nagore. Y por aquí haý de Pamplona al empalme de Espinal $55 \mathrm{Km}$ y a Valcarlos 77. Sólo se cumplirían, pues, por ambas rutas, los $7.4 \mathrm{Km}$ a Saint Jean de Pied de Port, que más o menos coinciden con las 5 millas del Summus al Imus Pyrenaeus del Itinerario, pero contando no desde Valcarlos-Luzaide, sino desde el mismo paso de Arnegui.

57 Mensúa, 1960: 13.

$58 R E$ III.1 (1895, col. 306-307). Según Peréx (1986: 173), la mansio Aquae Terebellicae se situaría en el actual Tarbes (Francia), al N. de Huesca, pero es casi imposible que la calzada derivara de tal forma hacia el Este, y habría más del doble de los 93,24 Km que de Terebellica a Burdigala da el Itinerario. Además la identificación de esta zona de aguas termales con la ciudad balnearia de Dax es segura, aunque carece de epígrafes probatorios (CIL XIII, p. 53), y sabemos que los galos Tarbelli estaban más cerca de la costa atlántica (cf. infra). Las distancias se cumplen bien, por Behobia y por Ibardín, a la aquitana mansio Carasa (mal ubicada en mi opinión, y sin pruebas, en el francés pueblo de Garris, bastante más al E, así en $R E$ III.2, 1895, col. 1569), si ubicamos Carasa mejor en el entorno de Bayonne/Baiona (si no es ésta misma), desde donde se cuentan casi exactamente los 57,5 Km a Aquae Tarbellicae. La célebre inscripción de Hasparren (por último Bost-Fabre, 1988: siglo III), posiblemente augustea, demuestra allí la temprana existencia de uno de sus pagi dependientes.

59 No dejo de tener en consideración el hallazgo de un ara al Sol en el Alto de Ibañeta (Castillo et al., 1981: $\mathrm{n}^{\circ} 23$ ), pero
1974: 143) me parece un desvío innecesario si el propósito es llegar a Oiarso y de allí a Aquitania. La tercera, que también el camino más directo desde Pamplona hacia el enclave marítimo de los vascones, Oiarso, es precisamente la que pasa por Velate. Si descartamos que la vía XXXIV fuera por Roncesvalles, se abren tres opciones desde Velate. Y las tres exigen una modificación del Itinerario de Antonino: Las millas desde Turissa a Summus Pyrenaeus deben corregirse siempre en [X]XVIII en vez de $X V I I I$, es decir, $41,440 \mathrm{Km}$. De tal forma tenemos estas tres posibilidades:

1) Desvío en Mugaire-Oronoz por Elizondo al Puerto de Otsondo, donde se cumplen aproximadamente los $42 \mathrm{Km}$ (las [X]XVIII millas que acabo de sugerir), y otros 8 a Dantxarinea/Ainhoa. Este paso, otra veces llamado «de Maya», tiene a su favor una posible ciudad y una ruta del siglo xil que lo seguía ${ }^{60}$.

2) Bifurcación en Vera de Bidasoa (Esteban, 1990: 83 ss.), a donde hay también $42 \mathrm{Km}$ desde Velate, para pasar los Pirineos por Ibardin/Herboure (asimismo unos $8 \mathrm{Km}$ ). Es posiblemente el mismo que al-Idrisi (1974: 143) llama «puerto de Bayona», por su lugar de llegada.

3) Pasar ya por Irún/litus Oiarsonis-BehobiaHendaya, radicibus Pyrenaei al decir de Plinio, aunque por aquí en el último tramo se contarían $13 \mathrm{Km}$ en vez de los 8 últimos del Itinerario.

La segunda, la de Ibardín, me parece con todo la

creo que se trata más bien de un paso secundario, como el de Urculu (¿Hércules?) más oriental, éste incluso con sus llamativos restos. La fama y el mayor uso del paso de Roncesvalles, aunque por supuesto se usara en época romana (como se ve, entre otros datos, por las excavaciones de J.L. Tobie en Saint Jean le Vieux, en el lado francés, o en los restos de calzada en el Alto Erro), deben obedecer a la época medieval y a causas posteriores, como la capitalidad del reino visigodo de Tolosa, o, más adelante, a las peregrinaciones, o al interés de algunas instituciones medievales en la zona, tal el monasterio de Saint Sernin de Toulouse, dueño de propiedades en Navarra en los siglos XII y XIII. Pero son destinos muy diferentes de los explicables en época romana y nada de ello se daba en el milenio precedente. Sobre este Portus Cicereus y los otros tres pasos pirenaicos occidentales en el siglo XII, cf. el-Idrisi, 1974: 143 e infra n. 63.

$60 \mathrm{El}$ texto es problemático de interpretar. Se trata de la ruta cantábrica de al-Idrisi (1974: 142-143). Dice que desde la desembocadura del río Sinadria (hoy Mayor, en el límite de Cantabria y Vizcaya) se va, a 45 millas, al río de Regina (desembocadura del Bidasoa), y a otras 50 millas a San Salvador de Olobide (scil., de Urdax), y tras otras 30 se llega a Bayona. Ésta es la interpretación de E. Saavedra (1881), pero es difícil de aceptar, puesto que no tiene sentido alguno bajar hacia el SE desde la costa, hasta Dantxarinea, para remontar nuevamente a Bayona, si se podían cruzar los Pirineos por la costa. De cualquier forma. como veremos más abajo, el paso de Dantxarinea cuenta ahora con una posible ciudad romana, de forma que habría que concederle más uso en la Antigüedad. 
ruta más corta cuando se quiere continuar a Burdeos. Pero la tercera tiene a su favor que se ajusta a la repetidamente citada calzada Tarraco-Oiassó. Ya se ha señalado que Bidasoa puede, en vasco, recordar el paso de un camino ${ }^{61}$. Por todo lo dicho, las mansiones de Summus Pyrenaeus e Imus Pyrenaeus habría que buscarlas por allí, en los pasos de Dantxarinea, Ibardin o Hendaya, preferentemente en uno de los dos últimos. En todo caso, es más lógico que Eturissa estuviera sobre esta ruta y no hacia Roncesvalles. No pretendo con estas nuevas hipótesis intentar además cuadrar las cifras (máxime cuando estarían pendientes de realizar prospecciones in situ), sino sencillamente sugerir, por una parte, que Eturissa debía de estar en la vía de Pamplona hacia la costa y hacia Oiarso y, por otra, que también es el modo más corto y lógico de llegar a Burdeos. Y éste, el sentido práctico y economicista, y no otro, fue el objetivo constante de Roma.

Recordaré, en cuarto lugar y a modo de prueba (por lo que sé nunca citada a este propósito), la ruta más corta por la que el retor y poeta bordelés Ausonio (III, 6; Mañaricúa, 1972: 234), a fines del siglo Iv d.C., aguardaba el regreso a Burdicala de su querido discípulo y senador, Paulino, largamente ausente en los bosques de los Vascones, en los nevados Pirineos: Esperaba con ansiedad verle llegar «a través de la tierra de los Tarbelli», es decir, por el camino paralelo a la costa que atravesaba la hoy francesa región de Labourdie, Laburdi, Lapurdum ${ }^{62}$, hacia Burdeos. Creo que si ésta, por el paso pirenaico más próximo a la costa ${ }^{63}$, era la ruta más directa para viajar desde el saltus Vasconum hacia Burdigala en el siglo IV, también debe ser la que seguía la vía XXXIV del Itinerario de Antonino, fuera por Hendaya o por Ibardín como más corta. Parece evidente el valor de este texto, por cuanto maestro y discípulo vivían y se carteaban entre los dos extre-

${ }^{61}$ Quizá lo mismo le puede pasar más adelante a Behobia, escrito «Beovias», en plural, junto a un castillito al pie del río, en el siglo XVII (mapa de W. Blaeu, cf. infra sub Tutela).

${ }^{62}$ Algunos autores identifican Lapurdum con la propia Bayona.

63 Pasos pirenaicos existían muchos. Al-Idrisi (1974: 143) señala los cuatro más practicables de toda la cordillera: Jaca (col de la Perche), Portus Asperus (Summus Portus-Canfranc), Portus Cicereus (Roncesvalles) y el de Bayona (Summus Pyrenaeus, según la hipótesis que he expuesto). Y, más adelante en el tiempo, el viajero inglés Charles R. Vaughan, en 1808 (1987: 186 ss.), dice que son numerosos tanto hacia Aragón (siendo el más importante el de Benasque) como hacia Navarra, donde cuenta siete, pero añade que no todos están practicables todo el año o son accesibles para carros. Entre los mejores, casi siempre abiertos, él destaca los de Irún, Saint Jean de Pied de Port, Vera, Echalar y Maya (scil., Dantxarinea). mos de la vía que discutimos. Y si en esta calzada XXXIV estaban el Summus y el Imus Pyrenaei, también deberíamos encontrar en ella la Eturissa que buscamos.

\section{3) Bitourís, Beturri $=\gtreqless$ Cirauqui?}

En este sector a analizar el punto fijo de referencia es Andelo. Pero como también tenemos un indicio epigráfico para considerar Tafalla como Curnonion (infra), debe ser mirado como en un espejo, ubicándose entonces al $\mathrm{O}$ de Pamplona Bitourís y Nemeturíssa. Y también porque, como dije más arriba, la Beturri del Ravenate, identificable con ella, debe estar «sobre Gracuse». Por su posición con respecto a Andelo y por haberse hallado un miliario en Añorbe, que apunta a una muy lógica calzada desde Muruartederreta hacia Estella ( ¿Araceli ${ }^{64}$ ), ésta misma o Cirauqui encajarían bien con la posición ptolemaica de Bitourís, sin descartar completamente Vidaurreta ${ }^{65}$, por su favorable posición sobre el río Arga. Como más abajo se verá, la «calzada del Arga», parcialmente estudiada por Bañales Leoz, será probablemente, después de las hipótesis que planteo, la que sigue el Ravenate.

\section{4) Nemeturissa $=i$ San Tirso/Oteiza?}

La tradición general sobre su nombre es la de la edición de Ptolomeo de K. Müller, que da Nemantourista, seguido casi sin excepción por todos los autores que han tratado de las fuentes vasconas (Tovar, 1989: C-511; Peréx, 1986: 180, etc.). Otras variantes de él dan Meniaturissa (mapa en color de Nicolaus Germanus, de 1470), Memanturissa (así en el de la edición de Ptolomeo de Florencia, de entre 1546 y 1548). En la cartografía de la Hispania antigua de A. Ortelius, de 1586, se escribe $\mathrm{Ne}$ manturissa, y Memiaturissa en el mapa del códice

${ }^{64}$ Tengo la impresión además de que, después de bifurcarse, la vía de Astorga entraba a Pamplona mejor por el $\mathrm{S}$, por Araceli; no vendría mal entonces esta ruta de Estella (donde el eco del topónimo y la evocación religiosa se encontrarían en su monasterio de «Irache»), aunque ahora no entro en la cuestión, que precisa más estudio, ya que el topónimo Araquil, por el $\mathrm{N}$, es también muy respetable, y supone argumentar una modificación casi completa de la vía desde Virovesca. Lo dejo, pues, sólo apuntado.

${ }^{65}$ Se ha ubicado, sólo por el parecido del nombre (Peréx, 1986: 90) en Bidaurreta, sobre el Arga, y en Vidaurre (Estella), contraviniendo ya (en apariencia) las coordenadas ptolemaicas, de lo que se quejaba Tovar, 1989: C-442, añadiendo que Bituris «no parece tan vasco como aquéllos, y tienta pensar que sea celta» (pero Beturri tiene otro aspecto). 
de la Universidad de Valencia. Namanturisa la llama Cortés y López (1835: 238 con n. 6), defendiendo su traducción como «Sofuentes». Como puede verse, una muy notable variedad, lo que certifica una mala transmisión del topónimo. Pero he encontrado una séptima versión en la antigua edición filológica de Sebastián Münster de 1540 (1966: 15) como Nementurissa, que me parece la más razonable de todas. Porque como conocemos el nombre de uno de los dos elementos, E/Iturissa (cf. supra), posiblemente el nombre original, maltratado por los copistas, fuera Nemeturissa ${ }^{66}$. En su composición parece aludirse a una zona boscosa ${ }^{67}$. J. Traggia la supuso en Bidaurre u Olaz. Cortés, ya se ha dicho, en Sofuentes. Müller en Siresa (scil., Hecho, HU., por CIL II, 4911, que sólo se conserva en Siresa pero no procede de allí) y A. Balil y J.M. Blázquez en Sos del Rey, Z.; M ${ }^{a}$ J. Peréx (1986: 180, n. 3), con dudas, al oeste de Jaca de Huesca.

De hecho, en el citado mapa de la edición florentina aparece, casi en fila, la serie Iturissa, Bituris, Andelus, Memanturissa, aunque colocadas todas al $\mathrm{N}$ de Jaca de Huesca. Sabiendo la situación real de una de ellas, Andelus, y que puede no ser cierta la ecuación Jaca=Iákka, es posible llegar por otro camino a la misma conclusión que he propuesto antes. Y si está al SO de Bitourís, según lo dicho más arriba, esto me lleva a pensar su ubicación en OteizaSan Tirso, y en buena parte por los cuatro miliarios hallados en la zona (Lostal Pros, 1992: núms. 86, 223, 224 y, relacionado, el $n^{\circ} 222$, de Andión). Allí, adosado a la ermita de San Tirso, se conservaba reaprovechado parte de uno ${ }^{68}$. Su epígrafe se refiere a Adriano, al cual se atribuye la creación de esta vía transversal o su conversión en vía empedrada.

En este caso, aparte de la existencia de los miliarios y de los indicios de construcciones (de «villa o pequeña población») que cerca de la ermita vio Jimeno Jurío, me lleva a proponer la ubicación de Nemeturissa, zona boscosa, en o cerca de Oteiza, el hecho de que ésta sea actualmente reserva de bosque mixto hacia el Este (bosques de Artajona-Añorbe: Mensúa Fernández, 1960, 70 con gráfico 23). Y también hacia el Oeste: En los mapas del Reino de Navarra de G. Blaeu de 1635 y en el del cartógrafo

66 A. Tovar ya apuntó que Nemanturista debía ser «un híbrido entre el nemeton celta y el vasco iturisa», pero no llegó a proponer un topónimo más correcto. Podría quizá valorarse por los filólogos la coincidencia en la sílaba -etu para explicar la síncopa (nemetu/eturissa).

67 Se trata del mismo radical de nemeton/nemus, bosque, entre los romanos no necesariamente sagrado; el irl. nemed s presupone la santidad del lugar. $C f$. la divinidad hispano-céltica Nemedus, Nemedus Augustus en Pedraza, SG. (Marco, 1993). holandés F. de Wit de 1680 se recoge aún, al SO de Estella y NO de Oteiza (más o menos hacia Montejurra e Irache), una masa boscosa y verde lo suficientemente importante, identificada como «Bosque del Condestable». Y también al SO de Oteiza, a menos de $7 \mathrm{Km}$, se ha conservado en su término hasta hoy al menos el encinar del Señorío de Baigorri. Así, en la zona de Oteiza, además de la correcta ubicación con respecto a Andelo y de la presencia de varios miliarios, se constata la antigua existencia de un németon, fuera Montejurra-Irache o un gran encinar. Y, por último, me parece que quizá ayude aquí la hagionimia: Porque es posible que se conserve el nombre de la ciudad en el santo al que está consagrada la zona, San Tirso ( $¿$ de un «turisso-tyrso» $\left.{ }^{69}\right)$, fenómeno relativamente común en España. De hecho, el paralelo aducible más próximo, en todos los sentidos, sería «Nuestra Señora de Andión», es decir, de Andelo, en las vecinas ruinas de aquella ciudad estipendiaria ${ }^{70}$.

\section{5) Kournónion $=\gtreqless$ Tafalla?}

Autores antiguos propusieron para esta ciudad, por la simple homonimia, lugares como Cornago, Cornaba, Cornava y Cornoino, donde, sin embargo, como ya señaló Tovar (1989: C-512) no hay restos arqueológicos; a causa de Ptolomeo, $\mathrm{M}^{\mathrm{a}} \mathrm{J}$. Peréx (1986: 147) la lleva «al oeste vascón, en la margen derecha del curso inferior del Ega y cerca del territorio de los várdulos».

En trabajo en prensa (Canto-Iniesta-Ayerra, 1997), al dar a conocer tres estelas funerarias, de Tafalla, Olite y Pueyo (ésta con los cognomina Cornutus y Cornutinus), y algunos restos romanos recientemente conocidos, ya hemos apuntado la posibilidad de que Curnonion fuera el nombre antiguo

68 J. Arce lo publicó en 1974 como inédito. En realidad, había sido visto y noticiado a medias, debido a la dificultad de su colocación, por J. M. Jimeno Jurío ocho años antes, en 1966 (Jimeno Jurío, 1966: 311).

${ }^{69}$ Puede recordarse aún que existe una ceca monetal del grupo navarro, poco representada y de sede desconocida, con leyenda Tirsos. Recientemente se hallaron dos ases más, con jinete portador, no de palma como se pensaba $(M L H I, 1975$ : A.45), sino de espada, como es más común en las cecas navarras, junto con un pequeño bronce escrito, en la localidad de Aranguren/Zolina, unos $9 \mathrm{~km}$ al SE de Pamplona, $c f$. Beltrán-Velaza 1993: 89 y fig. 3.

${ }^{70}$ No debe descartarse, por último, la posibilidad de la inmediata Artajona, también con un miliario (Bañales Leoz, 1992: 183-194) y, recordamos, con reservas boscosas incluso hoy notables. En el mapa citado de Blaeu figura otro bosque, menor que el del Condestable, entre Miranda de Arga y Olite, aproximadamente donde hoy se señala el lugar de «Moncayuelo». 
de la capital de la Navarra Media, Tafalla. Ubicada en el cruce viario (ibid.) entre la calzada Cara/Pompaelo desde el S (en la misma directa ruta que por Tudela cruza hoy el Ebro), y la que, procedente de la Jaca oscense, viene desde el Este atravesando la mediana navarra, con miliarios en Undués de Lerga, Javier, Eslava y Artajona. A su ubicación privilegia$\mathrm{da}$, en el piedemonte tafallés como enlace con Pamplona, hay que añadir incipientemente conocidos restos romanos, hallazgos monetales indígenas (especialmente de Bascunes) y un epígrafe perdido (Gimeno, 1989: 235 ss.). Su posición como capital económica de la Navarra Media ha perdurado siglos y ello hace suponer que, por mal conocido y estudiado que sea aún, su hábitat romano hubo de tener parecida relevancia. No me parece indicio de menor cuantía el que, al ser tomada por los árabes en la campaña de Pamplona del año 923-924 d.C., diga Arib ben Sa'id (Castilla, 1992: 181) que hisn Tafaliya era «una de las más importantes plazas del enemigo», y que pudieron saquear en ella «inmensas cantidades de víveres y recursos». Los textos relativos a esta sobreabundancia y comodidad de la ciudad se repiten en los autores posteriores ${ }^{71}$. Al final de la calzada sobre la que está Tafalla, en Burdigala (Burdeos), se documenta un único Curnoniensis $^{72}$. Y en el citado epígrafe, perdido, de su fortaleza $^{73}$, con toda la dificultad de la transmisión del texto, la línea 1 reza ACÍRSENIO CVR, marcando en el manuscrito el hueco entre ambas palabras. Quizá no sería muy arriesgado proponer Cur(noniensi) ${ }^{74}$. Si se confirmara este origónimo con la reaparición de la pieza, tendríamos casi asegurado el nombre antiguo de Tafalla ${ }^{75}$.

Me parece por fin muy interesante otro dato: En

71 Véase sólo un ejemplo en el poema del trovador tolosano Guillem d'Anelier sobre «La Guerra de la Navarrería», a fines del siglo XIII: "E quán él a sa guisa fo ben soyornat, anec ent Tafaila qu'es loc abastat», citado por J. Berruezo, en: Tafalla, 1990: 118 y passim.

${ }^{72}$ CIL XIII, 621: L. Hostilius Saturninus, Hispanus, Curnoniensis. Aunque, naturalmente, puede tratarse de una mera coincidencia.

73 Gimeno, 1989: El msc. BN 3246-3248 se debe según la autora quizá a P. A. Beuter, siglos XVI-XVII. Trata de linajes de España y, al terminar de describir escudos familiares de Olite, inserta la copia de un epígrafe funerario colectivo que ha visto en Tafalla: ACÍRSENIOO CVR/ TAANBASÍSÍNO $\beta$ CHEROHEHELLENI/ NIXXXV SOCHRE/ MATO SVO. MAÍ ${ }^{\circ}$ ALF AN.XXXV FEAC/ CILLA.FVSCINI.F/ D.S.P.F $F^{C}$. $C f$. su n. 11 para sus vicisitudes y destrucción.

${ }^{74}$ Es más discutible pensar que tras el -TAANBASI que sigue, en la compleja lín. 2, se esconde -NONIENSI, aunque no imposible.

${ }^{75}$ Un nombre que, por otra parte, ha dado muchos quebraderos de cabeza. En Tafalla existe una leyenda sobre su fundación por Túbal (que incluso ha conseguido encaramarse a su escudo) de donde vendría Tubalia. Como patriarca de la relación de los límites o corseras de la villa $(\mathrm{R}$. Ciérbide en Tafalla, 1990: 27) en época del rey Carlos II, a fines del siglo XIV, se citan: «... de Cascallar al Molino... deinde ad Santo Andrea... a Cornu del Vilar ${ }^{76} . .$. a la peça los Fraires...» Se compone así un aceptable conjunto de indicios, no definitivos pero sí muy sugerentes. Y, por último, no será el menor el que en las coordenadas ptolemaicas (figs. $8,9)$ Curnonion quede, como lo está Tafalla, casi en la vertical de Pamplona.

\section{6) Iákka $=i$ Ipsca/Isca? $=$ ¿Castil-Iscar?}

Como más arriba apunté (en n. 37), la identificación ya casi rutinaria (Peréx Agorreta, 1986: 160; Tovar, 1989: C-516, entre otros muchos) de esta Iákka ptolemaica con la Jaca de Huesca me parece imposible de compartir por tres razones: 1) La respetable distancia entre ellas. 2) No estar Jaca en el territorio vascón sino en el propio iacetano («el más conocido de los pueblos del valle del Ebro... hasta los alrededores de Ilerda y Osca», al decir de Estrabón III, 4, 10). Y 3) A interponerse entre ambos pueblos, según Plinio, los ceretanos (en este tercer sentido ya Taracena-Vázquez de Parga, 1946: 103). Hay que postular, pues, o dos ciudades del mismo nombre (la actual Jaca sí correspondería a la Pacca ravenatiana: 309,7 ) o un grave error ptolemaico. Opto, pues, por la duplicidad. Y tampoco exactamente, puesto que debemos estar además ante un error en la transmisión del nombre mismo.

los iberos, y en relación con el hierro, lo considera San Isidoro (Schulten, 1963: 329). Y bajo este punto de vista, por la importancia de la explotación del hierro en la antigua Vasconia, tiene una cierta lógica la leyenda. Es difícil su rastreo medieval. Más oportunidad tendría el nombre actual si obedeciera a un cambio visigodo. El único topónimo que pudiera tener un cierto parecido es Tallam, que he encontrado en la discutidísima División de Wamba (Vázquez de Parga, 1943: 83), en las variantes del territorio de la sede de Pamplona: Pampilona teneat de Cobello usque Mustellam, de Lericam (var. Loga) usque Tallam (var. Talla, Tollam) (cf. más abajo, nota 88). Una dificultad es que en Mustella partía el territorio con la sede de Calaurra (Calahorra: ibid:: 84 ), por lo que se debía haber mencionado otra vez a Tallam si fuera Tafalla. Lerica suena a Lerga, y Mustella quizá a Muscaria (cf. infra: Fontellas). Y la fuente es, por supuesto, muy problemática. Por todo ello, lo más posible es que el nombre sea árabe: al-Tafailla, «lugar del alto», que corresponde a su situación, puesto que aquí terminan las llanuras y comienza poco a poco la zona montuosa. Como al-Taffallia, aún con el artículo árabe delante, se la menciona en un documento regio del año 1158 (Jimeno Jurío, 1968: 114). En todo caso, parece claro que Tafalla no fue su nombre antiguo.

${ }_{76}$ No deja de ser llamativo este viejo microtopónimo, que tanto tienta a sobreentender «Villar del Cornu», «despoblado de Curnonio» o «del Cuerno», y que queda pendiente de localizar e investigar con más detalle. 
En el cuarto sector que he sugerido (fig. 9) para analizar el confuso territorio que Ptolomeo nos presenta, Iákka queda agrupada con tres ciudades sí bien conocidas: Grakourís, Kalagorína y Cásconton, las tres en la margen derecha del Ebro y posiblemente antes celtíberas. Al NE de ellas, y en una diagonal perfecta respecto de Gracchurris, se encuentra un interesante punto viario, Castiliscar, hoy de la provincia de Zaragoza. Presenta ocho miliarios, el mayor número de todo el territorio, lo que, según uno de los criterios antes expuestos, autoriza a pensar en alguna ciudad antigua en su término, y muy transitada.

Como en el caso de Carcastillo, que podría proceder de un castellum Cara $^{77}$, con el topónimo «Castiliscar» podríamos estar ante un castellum Iaka o, mucho mejor aún, ante un castellum Escar, lo que explicaría admirablemente el nombre moderno. En los mapas del siglo XVII ya citados aparece como «Castillescar». El nombre antiguo, fuera éste Isca, Ipsca, Iscar o Esca/Escar, encaja muy bien en la toponimia prerromana. $Y$ es que, de hecho, unos $34 \mathrm{~km}$ al NE de Castiliscar, se encuentra el topónimo «Escó» ${ }^{78}$ y, algo más lejos, los de «Salvatierra de Escá» y el río Esca/Eska. Aún más arriba existe el de «Burgui», otra vez en suelo navarro: Quizá el territorio de Iskka/Ipsca fuera extenso y tuviera un oppidum y un castellum más próximo a la vía. Otra ciudad Ipsca existe en el sur de España, que se ha conservado igualmente en el «Cortijo de Iscar», cerca de Castro del Río, en Córdoba. En Estrabón III, 4, 10 (distancias desde Ilerda), los msc. traen la forma Ískas, corregida en Óskas (Osca) por Xylander (con la que convienen las distancias).

Parece claro que la fama de la Jaca de Huesca pudo llevar al copista de Ptolomeo (o incluso a éste mismo, de sus informantes) a escribir aquí Iakka por Iska. Incluso la confusión entre las letras alfa y sigma interna griegas no es tan difícil. Obsérvese, por último, que, en las coordenadas ptolemaicas, una vez producido, como propuse al principio, el necesario desplazamiento del grupo inferior hacia el Este (debido, como dije antes, a la ubicación real de Ségia y Alauóna) (figs. 9 y 12) Iákka/Iska nos viene a quedar casi exactamente al $\mathrm{N}$ de Tarraga y al NO de

77 En una relación dúplice de ciudad llana y altura fuerte, como se da también entre Sangüesa y Rocaforte. Con respecto a Carcastillo, resulta curioso que el epígrafe que ha proporcionado el origónimo $k(a) r e(n) s i s$, la estupenda estela fúnebre de Porcio Félix (CIL II, 2962 = Castillo et al., 1981: ${ }^{\circ}$ 39; aquí fig. 2), justamente no procede de Santacara, donde se excava lo que se cree Cara, sino de Carcastillo.

${ }^{78}$ Escó (La Romana) está documentado como yacimiento romano en tierras aragonesas. Parecido es Escatrón (Cabezo de Muel), aunque ya más lejos y al Sur (Martín Bueno, 1977: 47 y 69-70; Arqueología, 1992: 223).
Ségia y Alauóna, como Castiliscar queda en realidad con respecto a Layana-Sádaba, Ejea y Alagón.

\section{7) Ergavica, Erguti $=$ ¿Berbinzana?}

Entramos ya en el quinto y último sector de los que he propuesto previamente para el análisis del texto de Ptolomeo, que da Ergaouia, sin duda por Ergavica. K. Müller, frente a la opinión de E. Hübner, ya defendió que existían dos ciudades de nombre Ergavica, una celtíbera y otra vascona (Tovar, 1989: C-476). La primera debe ser la más célebre y a la que se refiere Plinio, entre los pueblos de derecho latino viejo (III, 3, 24), hoy en la provincia de Cuenca; la segunda sería vascona y es la misma que el Ravenate llama Erguti. Para ésta se han propuesto, muy disparmente, los lugares de Milagro (NA), Albarracín (TE), Huerta-Bellida (CU), al sur de Cascante (Peréx, 1986: 149) y el despoblado de Yerga, «donde antes estuvo el monasterio de Fitero» (LO.) (J. de Moret) ${ }^{79}$.

El caso de Ergavica/Erguti era uno de los indicios para sospechar de la errónea coordenación de este quinto grupo de ciudades y justificar su traslado, como he propuesto, a la zona derecha u oriental de la rejilla de Ptolomeo: Esta ciudad no podría estar nunca al sur de Cásconton, como tanto se ha repetido, por dos razones en contra: Porque el Ravenate la da al N del Ebro y porque tanto Ségia como Alauóna sabemos dónde están en realidad. Según Ptolomeo, la posición de Ergavia (o mejor Ergavica: Plinio III, $3,24)$ debe ser, por una parte, al NO de Segia/Ejea y de Alauóna/Alagón, dos ubicaciones seguras; y, por otra - y en esto comparto la intuición de K. Müller- en relación con los ríos Arga o Ega, mejor el primero. Y debe estar, además, al norte de Gracusé. Si no fuera por estas dos condiciones - el río y el dato del Ravenate-, con gusto habría preferido, por pura lógica, colocar Ergavica en la zona de las Cinco Villas (porque cinco son también las ciudades de este sector), y más concretamente en Arguedas, más próxima y donde la ubicación ptolemaica se cumple perfectamente, además de existir restos arqueológicos (Etayo, 1926; Taracena-Vázquez, $1943^{80}$ ). Pero

79 Ésta última, propuesta por Moret debido «a la similitud del nombre», me parece inviable porque está al O de Corella y al S de Alfaro, lo que contradice a la vez tanto al Ravenate como a Ptolomeo.

${ }^{80}$ Conviene recordar que estos dos autores se pronuncian (p. 132), y enérgicamente, en contra de que Arguedas haya podido ser nunca mansio de ninguna vía, porque niegan en redondo un trazado Santacara-Tudela por la margen izquierda del Ebro y a través de las Bárdenas, en contra de la opinión de J. Altadill (pero $c f$. infra $s u b \mathrm{n}^{\circ} 14$ ). 
es el tener que ubicar Ergavica al N de Alfaro, a tenor del Ravenate, que seguramente remonta la calzada del río Arga, lo que me lo impide. Así, en la zona del Arga nos queda efectivamente un punto miliario, el de Berbinzana, que está además a orillas del río. La toponimia no proporciona ningún apoyo, puesto que su nombre actual parece árabe (Berbençana en el siglo XII, v. Corona, 1947: 31). Está, además, sobre el posible ramal desde Santacara a Estella, al N de Alfaro y al NO de Segia y Alauona. El nombre quizá significara «en la vía, junto al Arga» (Ergaouia en los msc. ptolemaicos) o, mejor «el vicus del Arga», si nos atenemos a Plinio para el nombre de la homónima ciudad conquense. Puede verse una prueba suplementaria de esto en el siguiente topónimo.

\section{8) Beldalin: ¿Bega, Bagara? $=\gtreqless$ ¿Vergalijo?}

Kromayer-Veith (en Tovar, 1989: C-437) lo ponía cerca del Ebro, diferenciándolo de Bursao/Bélsinon. Según A. Tovar (1989: C-441; Peréx no le dedica capítulo), el nombre debe estar alterado y propone precisamente la identificación con Belisone/Bursao $=$ Borja (C-437). Pero, a mi juicio, las tres corrupciones del nombre serían muy fuertes y Borja no está al norte de Gracuse, como indica el Anónimo de Rávena. Basándome para este caso sólo en que Beldalin debe estar al S de Erguti y al $\mathrm{N}$ de Gracuse, encuentro, precisamente sobre el mismo ramal Santacara-Estella, unos $7.5 \mathrm{~km}$ al Sur y antes de Berbinzana, el municipio de «Vergalijo».

Beldalin no comparece hasta el momento en ninguna otra fuente. Ya Hübner ( $R E$ III, 199) supuso que el nombre estaba corrompido, aunque no propuso corrección. De forma que podemos suponer que el topónimo no está bien transmitido en el Ravenate y quizá «Vergalijo» pudiera derivarse de una versión correcta de Beldalin, que no conocemos ( $¿ B e r g a-$, $B e g a-?)$. En tal caso, no podemos olvidar que tenemos en el bronce de Ascoli ( $C I L$ I $709=C I L \mathrm{I}^{2}$, fasc. 4, 1986, p. 936) dos origónimos aplicables: dos jinetes, un Begensis y un Bagarensis, de unas supuestas ciudades *Bega y Bagara de ubicación desconocida (Tovar, 1989: C-587 y C-606 ${ }^{81}$ ) pero de la misma conscripción reclutada desde Sallui.

${ }^{81}$ Bega según Tovar «entre los Pirineos y el Ebro». Gómez Moreno la hacía coincidir con la Baecula de los ausetanos. A Schulten le recordaba a los Baegenses béticos, confundidos por Degrassi -y ahora nuevamente por Krummreycon una Baegesis (CIL II 1394) de Marchena (SE.). El mismo Gómez Moreno sugería Bagara en el país de los jacetanos, todo ello incierto.
Como éste es el tercer topónimo ravenatiano de la serie Beldalin/ Erguti/ Beturri, acabamos viendo que con las tres reducciones que he propuesto coincide bien desde el Sur lo que para el Anónimo de Rávena podría ser el recorrido hacia el Norte de la calzada del Arga, vista desde Gracuse y el Ebro: Vergalijo, Berbinzana, (Andelo), Cirauqui, a Puente la Reina y torcer desde allí hacia Pamplona (figs. $12,13)^{82}$.

\section{9) Tarraga/Teracha $=$ ¿Layana-Sádaba?}

A. Schulten (RE IV A, 2403) la consideraba de situación desconocida. Y se ha colocado en Larraga, junto al Arga (Ceán, 1832: 149 y K. Müller, 191a), y con dudas en Tárrega de Lérida (por A. Tovar, 1989: C-520), ambas localizaciones muy improbables. La primera por su lejanía de Seglam/Segia, la ciudad de referencia fija en la ubicación de Teracha en el Ravenate, y la segunda por la misma causa y porque no es vascona. Más recientemente se ha llevado a Los Bañales de Uncastillo (Z.) (Peréx, 1986: $228)^{83}$. No sabemos si esta ciudad sería o no la federada del convento cesaraugustano que cita Plinio en III, 3, 24, con las variantes manuscritas tarracenses/tarragenses, pero es posible.

Desde mi forma de analizar el territorio ptolemaico, Tarraga resulta ser la ciudad más oriental de los vascones, al NE de Segia y Alauona. Como he mostrado al tratar más arriba del límite oriental vascón en relación con el culto del toro, ésta sería Farasdués. A este propósito, es muy significativo recordar que en el repertorio de caminos de Pedro Juan Villuga (1546/1967: s.p.), del siglo XVI, así como el de A. de Meneses (1576/1976: «XXXI», s.v.), la ruta que siguen desde Pamplona hacia Monzón de Huesca es: Tievas-Artederreta («Arte de Reta»)-Barásoain («Varasunay»)-Tafalla-Olite-Beyre-Murillo (Morielo)-Carcastillo-Sádaba-Biota ${ }^{84}$ Farasdués-Erla, en el límite vascón ( $c f$. supra), llegando ya al río Gállego por «Marcos»/Marracos. De esta ruta, que pasaría también por Luna, hoy no se conserva ninguna carretera moderna, siquiera secundaria, en los mapas corrientes, como tampoco del

${ }^{82} \mathrm{M}^{\mathrm{a}} \mathrm{J}$. Pérex (1986: 149 con n. 7) hace dirigirse esta calzada hasta Virovesca, seguramente siguiendo el criterio de K. Müller, 174. Roldán (1975: 127) dice que no conocemos este camino, y que la de Müller del enlace de Gracchurris y Virovesca es una simple hipótesis.

${ }^{83}$ Magallón, 1987: 151, 153, también con las referencias; duda entre Los Bañales y Larraga.

${ }^{84}$ La única diferencia entre ellos, aparte de las ortográficas, es que Villuga omite el paso (obligado) por Biota, antes de Farasdués. 
tramo Erla/Marcos (Marracos). Y, sin embargo, estaba en uso en el siglo Xvi y parece que pudiera corresponder a la más antigua y más corta hacia Caesaraugusta, al menos hasta Layana-Sádaba precisamente.

Por ello, y porque en Farasdués no hay indicios significativos de ciudad, al menos por el momento ${ }^{85}$, debemos preferir el amplio conjunto LayanaSádaba, debido a que está al pie de la via Augusta y entre Seglam/Segia y Carta/Cara, tal como ubica Teracha el Ravenate. Le conviene también lo antes dicho a propósito de la vía Santacara-Erla, y se cuentan además un miliario en cada término. El tramo Sora de Ejea-Ejea-Sádaba-Castiliscar se comprende expresamente mediante cinco miliarios, tres augusteos y dos tiberianos (Lostal Pros, 1992: 241243), que muestran que ésta fue la ruta que ambos emperadores consideraron de interés para el acceso, a través de Cara (con otros dos miliarios más de Tiberio), hacia Pamplona, Oiarso y Aquitania-Burdeos, tal como indica Estrabón, de ahí la propiedad del término de via Augusta, que ya usó Lostal. Por lo tanto, hemos de contar con un núcleo urbano prontamente desarrollado, que se demuestra a través de distintos e interesantes hallazgos arqueológicos (Peréx, ibid., sumando los de Los Bañales). Tampoco se cuenta con material epigráfico significativo a efectos de su denominación. Predominan en su territorio, como en el de Farasdués, los amplios pastos y las numerosas vacadas ${ }^{86}$. No obstante, en la fig. 12 , en la que traslado la propuesta previa de la fig. 9 tal como queda después de todas estas reducciones, dejo sugerida con líneas discontinuas una «segunda hipótesis» para este quinto conjunto, que llevaría Ergavica y Tarraga a Arguedas y Farasdués respectivamente. Pero, como dije bajo el número anterior, aunque resulta más parecida a la de Ptolomeo (fig. 9), tiene menos posibilidades de confirmarse, debido a la bastante precisa ubicación que da el Ravenate para su Erguti.

${ }^{85}$ No se conoce muy bien la zona a partir de Sádaba-Farasdués (a excepción del hallazgo de las aras taurobólicas del Corral Viejo de Moncho y algun otro) ni ha aparecido, hasta donde sé, ningún miliario de este tramo concreto. Lostal Pros (1980: 65) menciona sólo un yacimiento, próximo a la ermita de San Jorge, que parece de una villa, con cronología de los siglos I-II d.C. De ahí que sea más difícil postular aquí una ciudad. $C f$. Arqueología, 1992: 228, para el yacimiento del Cantal de la Higuera. El término «cantal» vuelve a referirse a un límite.

${ }^{86}$ Madoz, 1849: t. IV, p. 23, s.v. «Bárdenas de Sádaba», señala en ellas «abundantes pastos para numerosos rebaños de ganado lanar, y grandes vacadas que dan muy buenos toros para las plazas... esparto y arbustos...» (cf. supra, parte I).
10) Muscaria $=$ Despoblado de Mosquera, c. Fontellas

$M^{a}$ L. Albertos, en uno de sus mapas (1972: $352)$, sin concretar la razón, situaba esta ciudad en el área de Sádaba ${ }^{87}$, donde acabo de sugerir Tarraga. G. de Pamplona al oeste de Gracchurri (Peréx, 1986: 179). P. Bosch Gimpera y A. Schulten propusieron, sólo por el parecido toponímico, el despoblado de Mosquera, al N de Fontellas, con el acuerdo de Peréx (ibid.). Y, en efecto, puede aceptarse la reducción a tal despoblado, pero añadiendo algún otro elemento de juicio más sólido que la mera toponimia.

Como dije más arriba al tratar de Tafalla, he hallado una sola indicación textual, en el sentido de que uno de los límites de la diócesis de Pamplona en la División de Wamba (Vázquez de Parga, 1943: 83) era Mustellam, que sería corrupción del nombre romano ${ }^{88}$. Cuadra bien ese carácter limital con la posición del área de Mosquera-Fontellas sobre el Ebro, así como su casi correcta orientación en Ptolomeo con respecto a Segia/Ejea de los Caballeros. La derivación toponímica de Muscaria a Mosquera es muy aceptable. Pero he encontrado algunos datos más. No necesariamente tiene que venir el topónimo de musca, «mosca, lugar de moscas», sino quizá de «musgo» (muscus, muscaria) o de una especie de ave muscicápida, la muscaria, llamada hoy «moscareta» o «papamoscas», que se alimenta de insectos. Tanto el musgo como este tipo de aves son especialmente adictos a lugares con mucha agua, y ahora veremos la relación.

Existe una noticia muy útil para confirmar esta localización. Se debe al historiador cordobés Arib ben Sa'id, para el año 917-918 d.C. (Castilla, 1992: 150). Está refiriendo una campaña conjunta de los reyes Ordoño y Sancho contra Nájera: Se traslada-

${ }^{87}$ Quizá ello tuviera que ver con una curiosa hipótesis de M. Cortés y López (1835: 239 con n. 2), en el sentido de que "Sádaba» vendría de los nombres árabes Sebubi o Sabuvi, «las moscas... y de aquí el latino Muscaria». Curiosamente, P. Madoz, catorce años después (1849: t. XIII, 612-613) y sin citar a Cortés, propuso algo muy parecido: El nombre vendría de la voz semita Sebub/Sebubay, que los romanos se limitaron a traducir. El problema es que no veo claro que de ambos términos pueda derivarse satisfactoriamente el de «Sádaba», cuyo dominante no sería $S^{*} b^{*} b$, sino $S^{*} d^{*} b$, aparte de la vocalización en -a. Pero tenemos un dato mucho más concluyente.

${ }_{88}$ Cf. supra n. 75. Si de verdad fuera ésta la misma $M u s$ tella de la diócesis pamplonesa, sería mucho más adecuado que su nombre romano hubiera sido Mustaria. Éste explicaría mejor el Mustella godo, pero nos quedaríamos sin equivalencia con el topónimo y lugar moderno que mejor se acomoda, por lo que prefiero en este caso la fuente árabe que cito a continuación. 




Fig. 12.-Comparación con la fig. 9 del resultado del análisis sectorial de Ptolomeo después de la hipótesis de reducción propuestas, sobre las coordenadas reales. El curso del río Ebro es marcado por Kalagorína, Grakourís, Mouskária, Alauóna y Cesaraugusta. Con flechas, las dos calzadas cuyas ciudades cita el Ravenate.

ron luego a Tudela, llegaron al río Kalas (Queiles) y luego «a las aguadas de Musqira ${ }^{89}{ }$. Aparte de la mención del nombre mismo, casi igual ya a «Mosquera», y de la ubicación coincidente, es sugestiva la noticia de que era una zona de fuentes y manantiales, pues no indica en mi opinión otra cosa el

${ }^{89}$ En el al-Muqtabis V (Ibn Hayyan, 1981: 117), en la misma noticia, se traduce por «los alfoces». Pero dice Castilla expresamente que él traduce tal como viene en los msc. de ben Sa'id: «aguadas». nombre urbano más próximo actual, Fontellas: Fontalia, «lugar de muchas fuentes». También coincide con las varias «balsas», embalses y canales actuales en el área y tiene lógica que, desde allí, retrocedieran hacia Tarazona. Por todo lo dicho, es preferible el nombre que da Ptolomeo y, consecuentemente, ubicar con cierta seguridad Muscaria en el actual despoblado de Mosquera, con el intermedio árabe de Musqira y las referencias a los humedales. Para Tudela, que también se relacionaba con ésta, $v$. infra, Tutela, bajo el $\mathrm{n}^{\circ} 14$. Finalmente, $c f$. fig. 12. 


\section{1) Olca/Olcairun $=\succsim$ Olite?}

Fuera ya de las identificaciones basadas en los datos de Ptolomeo, que eran el objeto central de este trabajo, y del Ravenate, me quedan algunas otras ciudades con pistas por analizar. Entre Curnonion y Grachurris Ptolomeo no señala ningún núcleo. Allí se encuentra, sin embargo, Olite. Se ha tenido más habitualmente por fundación goda, hecha por los propios vascones rebeldes, forzados por los godos, para contenerlos, al decir de San Isidoro, en un precioso texto (Hist. Goth. 63) que, de paso, nos informa sobre la misma utilidad que debió tener el lugar, muy inicialmente, en época romana: En el año 621 d.C., reinando Suintila, «...montivagi populi... ut... Ologicum civitatem Gothorum... conderent...». $\mathrm{Cu}-$ riosamente, se suele traducir Ologicus por «Olígito» (así Jusué Simonena-Ramírez Vaquero, 1994: 23). De la misma manera, un sello céreo del concejo de Olite, del año $1291^{90}$ es leído «Sigillum iuratorum et concilii de Olito»; pero en el final, antes de la fractura que afecta al topónimo, no hay una $\mathrm{T}$, sino una $\mathrm{C}$ o $\mathrm{G}$. Si bien no hay duda de que para el siglo XII el comienzo del nombre había pasado a Olit-: Olitis/Olit en vez de Olog- (Jimeno Jurío, 1968: passim), también es cierto que la fuente literaria más antigua, San Isidoro, da Ologicus, con O y G o C. Recurriendo a la numismática, recordamos la citada ceca de Olca/Olcala/Olcairun ${ }^{91}$. Parece apropiado proponer que el nombre antiguo fuera Olca, de donde el paso a Ol(o)gicus, si difícil, es el más lógico ${ }^{92}$. De la misma opinión, aunque se basa en que es el único amurallamiento visigodo conocido de la zona, es R. López Melero (1987: 469).

\section{2) Ispallenses $=i \mathrm{c}$. Urdax?}

Los Ispallenses aparecen citados por Plinio III, 3, 24 , entre los diecisiete pueblos estipendiarios del convento cesaraugustano. Las variantes de los mss. plinianos en este nombre son muy variadas: Spallenses, Grallienses, Larnenses y Laurenses. E. Jan, para su edición, corrigió la lectura como [I]spallenses, ya que, en una relación alfabética, está entre los Dama-

\footnotetext{
${ }^{90}$ Ofrecen una espléndida reproducción en color Jusué Simonena-Ramírez Vaquero, 1994: 18.

${ }_{91}$ Como posible nombre híbrido celto-vasco (Olca-irun) lo toma J. Gorrochategui (1987: 438), aunque con problemas.

92 Terminado este trabajo, conozco el de J. Aldecoa Lecanda (1965: 17), que propone para la autoría de esta ceca a los olcades y para su ubicación, con dudas, las ciudades de Oyarzun u Olite. Pero la relación con los olcades es indefen-
} dible. nitani y los Ilursenses. El argumento no convenció a A. Tovar (1989: C-517), que prefiere Spallenses y los lleva con muchas dudas hacia Graus, en Lérida. Pero, por el contrario, la corrección de Jan me parece impecable a la vista de la metodología de Plinio. Por lo que sé, no se han propuesto otras posibilidades de ubicación para esta comunidad, ni se considera siquiera habitualmente que pueda ser vascona.

Ahora bien, existe constancia histórica (Madoz, 1945: 415-423; Puertas, 1975: 22, 254) de una célebre gira pastoral que, partiendo del monasterio de Leyre, efectúa, hacia el año 848 d.C., el cordobés obispo y futuro mártir, San Eulogio, a algunos cenobios pirenaicos, según relata él mismo en su Epistolario (Carta a Willesindo III, 2, cols. 850-1). Se citan entre ellos los monasterios Legerense, Cellense, Serariense y Hurdaspalense, más el muy importante de San Zacarías (que nada impide sea uno de los cuatro ya citados). La identificación del primero es sencilla y unánime con el de Leyre. De él parte Eulogio hacia el Cellense. Éste ha sido ubicado (Puertas, 1975: 22, con la bibliografía) en el valle de Ansó. Pero parece que si el obispo remontaba hacia las fuentes del Arga, debía ir desde Leyre derecho hacia el Norte, y este cenobio debía encontrarse mejor dentro del triángulo que forman las actuales carreteras NA-150, NA-172 y NA-135.

Del Cellense viaja hacia «el que más deseaba conocer», el «famosísimo» de San Zacarías ${ }^{93}$. Éste fue ubicado por J. de Moret en Cilveti, pero modernamente R. de Huesca, R. del Arco, E. Lambert y R. Puertas se lo han llevado hasta Siresa, en Huesca ${ }^{94}$ (Puertas, 1975: 21-22), a mi juicio erróneamente, puesto que el citado obispo indica con claridad que el de San Zacarías «está al pie de los Pirineos, ya a las puertas de la Galia, donde tiene sus fuentes el río Aragus, que baña en su rápido curso Seburi y Pampilona, antes de unirse al Ebro» (ibid., col. 846). Parece que ha habido un error de comprensión de los estudiosos modernos, pues el río que baña a Pamplona es el Arga. Su nombre romano quizá fuera, pues, Áragus ${ }^{95}$, mientras que el

93 Este ascysterium era rico en obras literarias que no se podían encontrar entonces en Córdoba. Eulogio se lleva de allí para su estudio, entre otras, las Avieni fabulae metricae (Vita III, n. 9; J. Madoz, 1945: 416).

94 En favor de esta hipótesis, aunque no la comparto, hay una curiosa noticia del Rasís: El señor de Huesca en el año 878, es decir, apenas 30 años después del viaje de San Eulogio, se llamaba Umar ibn Zakariyya, y se encontraba en el castillo de Yuliyo (?), cerca de Sartaniya (o Barbataniya) cuando fue desposeído por su primo, Zakariya ibn Umar ( $c f$. Vallvé, 1986: 298). Se ve que el nombre de Zacarías era frecuente en el área.

95 Es curiosa la vecindad de tres ríos importantes con nombres tan similares: E(r)ga, Arga, Arrago. Esto hace pen- 
del Aragón sería más bien Aragó/Arragó ${ }^{96}$ (de donde Arragonia), de forma que Siresa, aunque haya conservado un monasterio tan importante como el de San Pedro, se encuentra demasiado lejos de las fuentes del Arga, en el coll de Urquiaga. R. Puertas se pregunta cómo no da el obispo el topónimo del célebre monasterio de San Zacarías; pero éste me parece ser el más abajo (cols. 850-851) mencionado Serariense, por dos razones: $\mathrm{Su}$ abad tiene el mismo nombre que el de San Zacarías, Odoarius; y también se repite en ese fragmento de la carta que ha visitado el de Leyre ${ }^{97}$. Por último, finalizando su largo pero grato viaje hacia el Norte, San Eulogio visita el cenobio Hurdaspalense, con toda su comunidad y su abad Dadilanis. R. Puertas (1975: 22) había visto ya, a partir del primer elemento de este nombre, Hurda-, que este monasterio, quizá predecesor del de San Salvador, propietario durante siglos del término (Madoz, 1986: 371) debía hallarse cerca del actual Urdax, que encuentro se llama «monte Urdaspal» en 1085 (Corona, 1947: 130), en el valle de la Nivelle e inmediato al puerto pirenaico de Dantxarinea.

Pero no se ha relacionado, por lo que sé, el segundo elemento de este topónimo, -spalense, con aquellos corregidos Ispallenses de Plinio. Siendo un nombre tan poco frecuente, creo que se puede proponer que esta ciudad estipendiaria sería vascona, su nombre sería probablemente Ispallum y su ubicación en o cerca del actual Urdax. La situación en esta ruta de dos monasterios y una ciudad sugiere una revalorización del paso de Dantxarinea en época romana. Se trataría, por cierto, de la ciudad interior más septentrional de los vascones.

\section{3) Seburi $=$ ¿Zubiri?}

Esta ciudad, con el nombre vascón de ciudad, -uri, a diferencia de todas las anteriores, no aparece citada en fuentes de época romana, sino en la misma correspondencia de San Eulogio (ibid. col. 846, cf. J. Madoz, 1945: 416 con n. 2; Puertas, 1975: 253, apéndice B-258), por tanto, en una fuente del

sar en un nombre primitivo común para ellos, con determinativos especiales que no conocemos, y recuerda asimismo la reduplicación afrontada del Cidacos en el mismo o inmediato territorio.

${ }_{96}$ Con muy posible acentuación final, ya que así es el nombre árabe posterior del río, Aragûn (Terés, 1986: 64). Y Aragón el nombre final de esta actual comunidad autónoma.

97 Siendo así, cerca de las fuentes del Arga, aparte del propio Cilveti, encontramos como en algo parecidos el alto de Zuriain y el arroyo Suariain; éste puede haber conservado una primitiva Seraria(na), por el principio de -ana/-ain. siglo Ix. Al describir el curso del río Aragus (como ya dije, no el Aragón, sino el Arga), cerca de cuyas fuentes está el monasterio de San Zacarías, dice de él: ...quibus Aragus flumen oriens, rapido cursu Seburim et Pampilonam irrigans, amni Cantabro (scil., Hibero) infunditur.. El texto dice Cantabro, pero parece evidente que, una de dos, o poéticamente llama al Ebro «el Cántabro» por su origen ${ }^{98}$, o existe un error en el texto. La primera hipótesis es la que me parece aquí preferible.

No hay más ciudad posible que bañe el Arga antes de Pamplona que la actual Zubiri ${ }^{99}$, al pie del Alto de Erro, y donde se bifurcarían las rutas romanas pirenaicas en dirección a los puertos de Ibañeta y Dantxarinea. El lugar, pues, no puede ser más idóneo para la ubicación de otra ciudad vascona que, como tantas otras ${ }^{100}$, no se conservó en las fuentes romanas que hasta nosotros han llegado.

14) Tutela y el Ager Tutelatus = Tudela y las Bárdenas Reales

A lo largo de este estudio me intrigaba la predominante y favorable posición de la ciudad de Tudela, junto al Ebro (y, lo que no es menos importante, al pie del río Queiles), sin que fuera mencionada en ninguna fuente greco-romana, ni mereciera casi atención por la mayor parte de los investigadores modernos. El Queiles, según afortunada reducción de A. Schulten ${ }^{101}$ es el que los antiguos llamaron Chalybs, quizá como un cultismo en honor de los legendarios forjadores asiáticos del acero. Tudela, independientemente de que tuviera también una actividad metalúrgica gracias a las cualidades del mis-

${ }_{98}$ En el que en definitiva el Arga desemboca, tras un corto tramo conjunto con el Aragón.

${ }_{99}$ Esta hipótesis ya fue formulada muy antiguamente por J. de Moret, pero luego ha debido ser olvidada, pues los autores modernos, incluso Antonio Tovar, no mencionan, no ya la hipótesis, sino ni siquiera la existencia del topónimo como tal.

${ }^{100}$ Quién sabe si los antes citados monasterios Cellensis y Serariensis (por no salir de un único párrafo de San Eulogio), no corresponderían a microtopónimos, sino a otras dos ciudades vecinas, una Cella/Cilla y una Seraria... Un estudio atento, en el que no me he podido detener ahora, de todas las ricas fuentes medievales, visigodas, árabes y cristianas, elevaría sin duda el censo de posibles ciudades vasconas vivas en época romana. Me parece limitado ceñirse a los nombres que las fuentes greco-romanas supervivientes nos ofrecen.

101 Cf. el capítulo que al trabajo del hierro (1958: 328336) dedica Schulten en su espléndida monografía, en edición española de 1958-1963. Es a mi juicio uno de los mejores libros de conjunto que se han escrito sobre la antigua Hispania, y es lástima no verlo utilizado ya (o al menos citado) con la frecuencia que merece. 
mo río Queiles ${ }^{102}$, tuvo al menos que tenerla económica en la salida de las mercancías al tráfico fluvial del Ebro, navigabili commercio dives... navium... a Vareia oppido capax (Plinio III, 3, 21) o, como mínimo, de vigilancia de aquél.

J. Oliver Asín dedicó las primeras páginas de su trabajo sobre los orígenes de esta ciudad (1971: 495 ss.) a demostrar que la etimología de Tudela desde un romano Tutela era insostenible; entre otros seis argumentos, porque no encontraba base histórica o geográfica para la elección de un abstracto como «defensa, protección». Él mismo señala también que nunca se ha descubierto «dentro o en los arrabales de la ciudad, algún resto o recuerdo epigráfico, numismático o arqueológico... cosa... que... lamentaron siempre quienes sostuvieron, a pesar de todo, la errónea etimología» (ibid.: 497). Ésta es poderosa razón, pero quizá pudiera encontrársele también alguna causa. Intentaré demostrar, pues, que Tutela es romana, aunque se ubicara en tiempos en la margen frontera del Ebro, y una razón para el peculiar nombre.

El topónimo claramente procede de una latina Tutela (así Schulten RE XIV, $1965^{2}$, col. 1608, $\mathrm{n}^{\circ} 8$; Tovar, 1989: C-531: «no documentada») ${ }^{103}$. Creo que aquél, además de por la estricta equivalencia toponímica, se puede confirmar en la Tudela navarra por tres vías. La primera, su mención en un conocido epigrama de Marcial ( $c f$. infra), citando lugares de su tierra celtibérica: Tutelamque chorosque Rixamarum. A pesar de opiniones como la citada de $\mathbf{J}$. Oliver, en el sentido de que se trata de un nombre común ${ }^{104}$, la conjunción enclítica que une ambos

${ }^{102}$ Es el Queiles al que las fuentes medievales árabes llaman wadi Tarasuna y wadi Qalas, Kalis o Kalas (cf. Terés, 1986: 113) y Kelles las crónicas cristianas (Dupré, 1995: 19 con n. 9). V. mi libro en preparación Fuentes árabes para la Hispania romana. Es el mismo que baña Turiasso, y famosos eran ambos, al decir de Marcial $(4,55)$ y Justino $(44,3,8)$, por la calidad del temple de las armas que en ambas se forjaban, debido precisamente a la fuerte carbonatación del río, que también bañaba Cascantum. Lo mismo ${ }^{\circ}$ afirma Plinio (XXXIV, 144) de Bilbilis con respecto al río Jalón.

${ }^{103}$ Creo muy difícil que, como sugiere Oliver (1971: 505 ), viniera de un medieval cristiano Todella, relacionándolo con las famosas reinas navarras de nombre Toda o Tota ( $\mathrm{p}$. 506), ni verosímil históricamente que, al bautizar sus fundadores árabes una «nueva» ciudad, vinieran a pensar precisamente en «honrar a alguna dama de nombre muy godo, y muy navarro, y muy aragonés» (p. 509) y porque tal nombre, aunque fuera godo, habría dado, como en los casos que el propio Oliver cita (Totainville, Totana, Todmir), Totela o Todela y no Tutela, con u; Tudelas o Tudelillas son también todas las muchas homónimas de otras zonas de España.

104 Oliver (1971: 495) comienza su estudio afirmando que es erróneo ver en este verso esta palabra como nombre propio, tal como sí habían hecho Traggia, Cos, Eyalayar, La Fuente, Schulten y Dolç; pero él mismo se olvida, al final del trabajo, de volver a Marcial para darle una explicación como nombre común. elementos me parece indica que ambos son nombres propios. La segunda confirmación es su mención en la Chronica Albeldensia, cap. 13 (Gil-MoralejoRuiz, 1985: 252): Hoc supra dicto principe regnante (scil. Alfonso III) in era DCCCCXX (a. 882-883) profectus ad Tutelam castrum preliauit... Sabemos por ella que su nombre en latín era Tutela y suponemos que entonces tenía más aspecto o características de lugar fortificado, de un castellum, que de propiamente ciudad (debido quizá a que la «nueva ciudad», edificada a comienzos de aquel mismo siglo por alHakem I y Amrús al-Muwallad, en el 802 d.C., estaba muy fortificada), aunque los autores árabes la llaman «ciudad» (Madinat Tutila: Vallvé, 1986, 301) y le conceden grandes alfoces (pudiera ser también que ello indicara dos hábitats próximos de distinto tipo y función). La tercera es una fuente árabe, la más antigua crónica andalusí, del ya citado cordobés Arib ben Sa'id, fuente de Ibn Hayyan y de Ibn Idari (Castilla, 1992: 9 y passim). En su descripción de las campañas árabes contra la Marca Superior de los años 906 al 924 d.C. la menciona seis veces como ciudad (propia del Islam), llamándola, como en la crónica anterior de al-Hakem, Tutila. Por lo tanto, creo que sí está documentado el nombre romano de Tudela en las fuentes posteriores.

Ha jugado siempre en contra de su existencia pre-árabe (así Oliver Asín, por ejemplo, o su mera mención en estudios de época romana) la relativa ausencia de testimonios romanos en la actual Tudela, en la margen derecha del Ebro. La noticia de la construcción por al-Hakem de una «nueva ciudad», poblada con gran número de musulmanes, en el 802 d.C., es referida en la Descripción anónima de alAndalus (Molina, 1984: t. II, 140) y en la crónica de al-Rasís. Cabe imaginar si, considerando el anchuroso Ebro como una frontera más segura para los árabes (Tudela se cita en el Muqtabis V como la última plaza musulmana, y como «una de las puertas de entrada a los infieles»), no la reedificarían éstos mejor en la margen derecha, y si la romana Tutela no debería ser buscada quizá enfrente de la actual, donde se conserva un llamado «barranco de Tudela», que es ruta de paso natural, estratégica, y vía principal de comunicación E-O desde al menos la Edad del Bronce ${ }^{105}$. Quizá ello explicara que en la

105 Sesma, 1993, 100: Su grupo III de yacimientos, con seis, en dos bandas paralelas, dominando la citada ruta. Este autor, al hablar de su valor estratégico, resalta que la única carretera comarcal que hoy atraviesa las Bárdenas es precisamente la que va paralela a aquélla, controlando también los accesos desde la Ribera del Ebro y desde el Sur. Aquí encajaría también la vía que a J. Altadill le parecía podía subir por la margen izquierda del río, y que negaron Taracena y Vázquez de Parga (cf. supra). 
Tudela actual no se constaten hallazgos anteriores a los árabes.

Por lo que hace al nombre mismo de Tutela, no resulta muy adecuado a primera vista en su acepción de «defensa», dándose las circunstancias apacibles con respecto a la romanización del territorio vascón que todos damos por hechas, al menos en lo que al ager Vasconum se refiere ${ }^{106}$. La fundación de Gracchurris, en fecha tan temprana como el 179 a.C., habla a favor. La pregunta consecuente es: ¿Qué había que «tutelar» aquí? Entonces es cuando invito al lector, en tercera instancia, a observar un detalle que se desprende del estudio que tiene en sus manos y, más concretamente, de sus mapas. Si retrocedemos a dos que aquí he ofrecido, el de distribución de hallazgos relacionados con el culto a la luna y el toro (fig. 1) y el de miliarios y calzadas (fig. 10), puede constatarse en ambos un muy significativo vacío - casi diría una aparatosa ausenciade testimonios de todos esos tipos en un espacio enorme, arqueado, con una longitud que va desde más o menos el cauce bajo del río Aragón, es decir, Cara, hasta casi el actual Tauste. A lo ancho, una distancia máxima entre Arguedas y el área SádabaEjea. La pista inicial, pues, nos la facilita el dato negativo de los mapas: La falta de hallazgos, vías, miliarios o ciudades. El tramo digamos «en blanco» ocupa una superficie no inferior a los $1300 \mathrm{Km}^{2}$, abarcando tierras de Navarra y Zaragoza ${ }^{107}$. Parece desierta y despoblada (y aquí uso el estricto término castellano, «sin pueblos»), seguramente desde tiempo inmemorial. Coincide, según creo, con el extenso territorio que seguimos conociendo como «Las Bárdenas ${ }^{108}$ Reales», propiedad hoy aún pública, del Patrimonio del Estado, y cuyo sector central, la «Bárdena Blanca», ocupa el célebre y polémico polígono de prácticas de tiro áereo ${ }^{109}$.

${ }^{106}$ La posibilidad de que se tratara de una diosa local interpretada como la Tutela romana (Tovar, ibid.) tendría mejor cariz, pero tampoco tiene pruebas.

107 Debía ser mucho más extenso en la Antigüedad. A la zona navarra corresponden hoy unas 45.000 hectáreas. Pero, como es obvio, analizo el conjunto del territorio independientemente de en qué provincias esté hoy, porque en época romana esto era todo convento cesaraugustano, y más según lo dicho en la parte I: Que, geográficamente, no hay tal frontera con Aragón.

${ }^{108}$ El nombre se pronuncia de distinta manera según lo hagan los roncaleses (Bardená), los riberos (Bardena) o los aragoneses (Bárdena), lo que debe tener que ver con hábitos lingüísticos diferenciados y antiquísimos, apoyando la idea de mixtificación que desde la filología se ha apuntado muchas veces. Me es más familiar el de Bárdenas, que es el aquí utilizo.

109 Véase, de forma general, Hernández Pacheco (1949: 427-440) y la monografía editada por el Depto. de Ordenación del Territorio del Gobierno de Navarra (Pamplona, 1990), con la bastante completa bibliografía que se facilita en su pág. 63. Para estudios arqueológicos recientes, $c f$. infra.
Cualquier definición de esta zona, que los árabes llamaron Yabal (montes de) al-Bardi, es muy similar a ésta que elijo: "Comarca natural que se extiende en la margen izquierda del valle del Ebro, sobre la zona SE de Navarra y la O de Zaragoza. La extraordinaria sequedad del clima impone el predominio de la vegetación esteparia, con carácter semidesértico, por lo que el poblamiento es muy escaso. Imperan la explotación del ganado ovino trashumante y el cultivo extensivo de cereales, que aumentará notablemente con el reciente aprovechamiento de aguas por medio de obras de regadío que han permitido surgir en poco tiempo numerosos poblados» ${ }^{110}$. Se atribuye, pues, su crónico despoblamiento a la sequedad climática, la vegetación esteparia y su carácter semidesértico ${ }^{111}$. Pero, como ocurre con el resto de la península, ello no pudo ser siempre así, y debe rastrearse con más detalle el pasado documental de este singularísimo territorio. Pascual Madoz (1849: t. IV, 22-23), al que seguiré en este tramo especialmente, da como límites a las «Bárdenas» (distintas de las colindantes «Bárdenas de Sádaba») los montes de Rada al Norte, Fustiñana al sur, Sádaba al Este y Las Corralizas de Arguedas al Oeste, y una superficie de $7 \times 5$ leguas, es decir, unos $1080 \mathrm{Km}^{2}$. Les dedica luego un detallado comentario histórico, que arranca con la donación, en 1094, del rey Sancho Ramírez, del aprovechamiento de la Bárdena de su propiedad ${ }^{112}$ en favor del pueblo de Arguedas, para pastos, siembra, leña, carbón y corte de maderas. En el siglo siguiente (año 1117) pasó el derecho a Tudela, Valtierra y Cadreita (Fuero de Sobrarbe), y en 1204 a una «hermandad» formada por 15 municipios na-

110 En el más reciente mapa que conozco, el del Atlas $\mathrm{Na}$ cional de España, sección I, grupo 3a, escala 1:500.000 (Madrid, junio de 1994), págs. 8-9, sigue, a pesar de los pronósticos, apareciendo bastante desierta; se aprecia por primera vez una carretera (la 125) que atraviesa por el S. en dirección O-E, de Tudela a Ejea, pero muy pocos pequeños núcleos, todos modernos (Pinsoro, El Sabinal, Santa Anastasia...).

${ }^{1 .}$ Véase la categórica opinión de B. Taracena y L. Vázquez de Parga (1943: 131): «La vía (Sangüesa-Cascante, propuesta por J. Altadill) se halla obstaculizada en un tramo de $20 \mathrm{Km}$. por el desierto de las Bardenas Reales, llanura hoy como entonces inhabitable por absoluta carencia de agua». A. Floristán (1949: 475), criticando la definición del Diccionario de la Academia de la Historia y a algunos otros autores, se queja de que «se ha convertido en lugar común hablar de la espesa selva que fue en tiempos la Bardena...», adhiriéndose a opiniones como las de B. Taracena, a quien le recuerda mejor «la inmensa llanura desértica del Sur tunecino...».

${ }_{112}$ Creo que una cita anterior podría encontrarse hacia la segunda mitad del siglo XI en el geógrafo andalusí al-Bakri (1982: 16). Cuando describe el tercero de los distritos de la división constantiniana menciona, tras Tutila, «todos los distritos del territorio del rey Sancho» (es decir, Sancho de Peñalén, rey de Pamplona a. 1054-1076). 
varros y 8 aragoneses, todos ellos circundantes. Los navarros eran: Tudela, Murillo, Arguedas, Valtierra, Cadreita, Alesvés (Villafranca), Milagro, Funes, Peralta, Falces, Caparroso, Santacara, Villaruruz ( sic), Murillo el Fruto y Carcastillo; los aragoneses: Tauste, Ejea, Luna, El Bayo, Luesia, Biota, Erla y Sádaba. La forma de alcanzar el beneficio de la Bárdena hasta cerca de Erla y Luna creo que apoya la anteriormente expuesta idea ( $c f$. supra parte I) acerca del límite oriental de la Vasconia romana. Su número, 23 , da buena idea de las capacidades y riqueza de la extensa reserva regia, que, a todas luces, nada tenía entonces de semidesértica ni esteparia. De hecho, en el tiempo de Sancho el Fuerte se describe la zona como «quebrada y cubierta de boscaje» (Taracena, 1947: 18).

Consta en los siglos siguientes bastante documentación sobre sucesivas concesiones reales, rentas para el monarca, disputas por el disfrute, el régimen de pastos (de octubre a mayo) y el de corte de maderas. En 1413, por ejemplo, se mencionan sus pinares. En el siglo Xvi el alcalde de Tudela presidía las Juntas, y en el XVII este mismo pueblo gozaba de privilegios sobre los demás, pues se le confirman en 1630. En 1705 Felipe V (quizá por su distinta mentalidad o, mejor, apurado por las necesidades de la costosa Guerra de Sucesión), vendió definitivamente los derechos perpetuos sobre la Bárdena, por 12.000 pesos, a una nueva confederación formada por 20 municipios, el monasterio de La Oliva y dos valles pirenaicos, Roncal y Salazar, que llevaban allí sus rebaños intermitentemente al menos desde $1358{ }^{113}$. Esta confederación redactó en 1820 sus Estatutos ${ }^{114}$. Se prueba por ellos, según el detallado relato de Madoz, que todavía en 1820 había caza, y lobos, cuya captura estaba premiada. Los pueblos co-gozantes tenían estatutos, comisiones de vigilancia, monteros, guardeses y reuniones trianuales allí mismo, en la iglesia de la «Virgen del Yugo», desde donde se dominan la Bárdena Blanca y la Negra. Pero, a tenor de esta regulación, puede verse que ya había pasado a uso principal el ganadero, mencionándose además sólo la leña y ésta muy secundariamente. Es decir, que para entonces (funesta tendencia hispana) había perdido ya mucho de los que debieron ser grandes valores forestales. Curiosamente, en varios de los documentos se le llama también al territorio «la Bárdula».

113 A éstos se suma hoy en día, como un propietario más, el Ejército del Aire.

114 Hoy se rigen por una Junta General, y con unas Ordenanzas aprobadas en lo esencial en 1961. La sede de la Comunidad de Co-gozantes (o Con-gozantes, como se llaman ellos) sigue estando en Tudela (Bárdenas, 1990: 16).
Pero durante la segunda mitad de esta interesante historia de nueve siglos podemos echar mano de otro tipo muy expresivo de fuentes. En el mapa del Reino de Aragón en colores, dibujado por João B. Lavanha, y terminado hacia 1615 , se designaba a este amplio territorio como «Bárdena del Rei», y llegaba igualmente hasta el $\mathrm{O}$ de Tauste, cerca del río Riguel. La parte navarra, como es lógico, presenta menor detalle, pero se ve desierta de poblaciones. En el de W. y J. Blaueu, del mismo Reino de Aragón, basado en el anterior de Lavanha, hay poca diferencia, excepto en que se colorea más de verde la zona norte de la «Bárdena del Rei». En cambio, en el que ejecuta solo J. Blaeu en 1635 , específico del Reino de Navarra, aparece descrita el área como «Bárdena Real» (fig. 11), con mucho más detalle y delimitándola exactamente, con lo que se puede apreciar su enorme extensión y su estricto deslinde con respecto a las demás merindades y reinos. Según la escala que usa, le asigna una longitud O-E de 9 leguas hispánicas por una latitud $\mathrm{N}-\mathrm{S}$ de 5,8 aproximadamente, lo que da una superficie media espectacular de 52.2 leguas cuadradas, es decir, unos $1620 \mathrm{Km}^{2}$, bastante más de los 1080 $\mathrm{Km}^{2}$ que, como dije, parece medía hacia $1850^{115}$. Llega igualmente hasta cerca de Tauste; figura ocupada por un sector de pequeñas alturas al $\mathrm{S}$ y el resto con abundante bosque verde, lo que no deja lugar a dudas sobre su cualidad, puesto que sólo dibuja otras dos manchas boscosas en todo el reino ${ }^{116}$.

El mapa de Navarra del también holandés F. De Wit, de 1680 (que por otra parte es prácticamente un calco del de J. Blaeu), presenta el territorio casi de igual forma, extendido de $\mathrm{O}$ a $\mathrm{E}$ y con forma arqueada. En estos dos casos, viene a consumir casi la mitad de la merindad (maiorinatus) de Tudela (por lo que vemos que administrativamente le correspondía), entrando de forma apuntada en la provincia de Zaragoza y siempre con un único punto notable construido, a media distancia y hacia las alturas de la parte del Ebro: El castillo de Sancho Abarca ${ }^{117}$,

115 Aunque puede tratarse de un defecto de medición, creo más posible que la diferencia se deba también a que para 1849 se habían segregado ya las aún ahora llamadas «Bárdenas de Sádaba», por el hecho de que Madoz (ibid.: 23) las describe separadamente, aunque sigue habiendo una notable diferencia de medidas. Como diré más abajo, ha perdido bastante de su primitiva extensión, según nos dejan ver algunos microtopónimos hoy exteriores a ella.

116 Las que más arriba he citado a propósito de la posible ubicación de Nemeturissa, v. supra.

117 En el interior de las Bárdenas existen otros pequeños castilletes, como los de Aguilar, la Estaca o Santa Margarita, Mirapeix, Peñaflor, Peñarredonda y Sanchicorrota, a veces simples torres de vigilancia (Bárdenas, 1990: 12). 


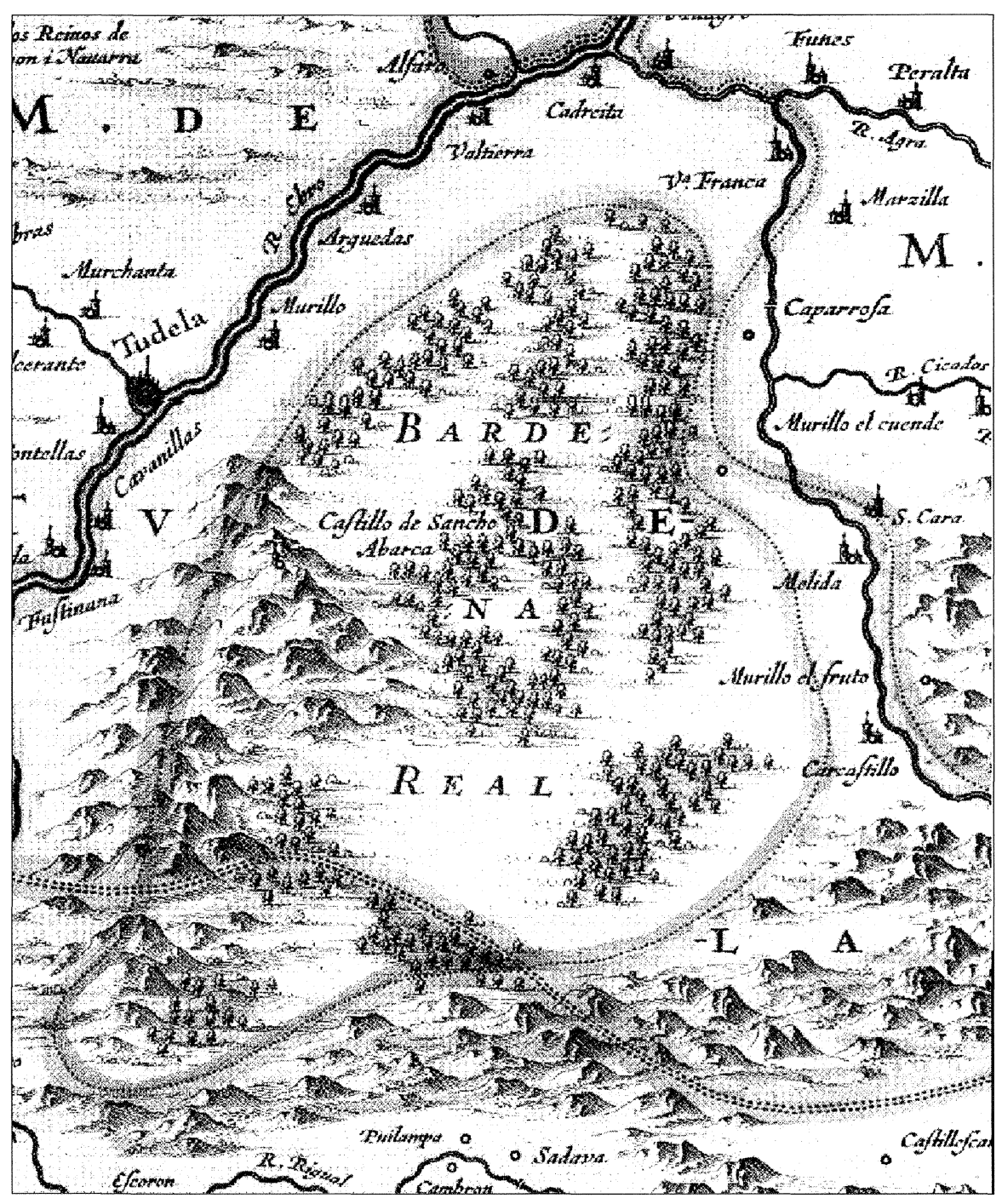

Fig. 11.-Detalle de la «Bárdena Real», del mapa del Reino de Navarra de Johannes Blaeu, muy arbolada aún en el año 1635.

nombre que, como singular «advocación», pasó a una ermita en otro punto, más hacia Tauste, y hoy reducido a simple punto habitado. En mapas actuales se apunta también otra ermita, la ya citada y de extraño nombre de «Nuestra Señora del Yugo», en pleno polígono de tiro. De la amplitud del territorio da idea el que figure incluso, lo que es insólito por la gran escala, en el mapa general de España llamado «Teatro de la Guerra en España y en Portugal», de P. Mortier, de 1710, visible como «Bárdena Real». Así pues, estos testimonios gráficos confirman también la existencia en su interior, aún en el siglo XVII, de amplios bosques, si bien clareados por dehesas de pastos, tierras de cultivo de cereal y al- gunas zonas montuosas o improductivas ${ }^{118}$. Creo que lo dicho hasta aquí demuestra varios hechos:

1) La inusitada extensión de Las Bárdenas Reales, enclavadas sin embargo en el corazón de un territorio muy poblado.

2) Su carácter en general boscoso, probable al menos desde el siglo XI hasta el xvir, frente al engañoso aspecto estepario actual.

118 Bárdenas, 1990: 27-28. Determinadas zonas del territorio, como parte de la Bárdena Blanca, no pudieron tener arbolado o cultivos tampoco en la Antigüedad, debido a la extrema salinidad de los suelos y a una dinámica erosiva continua. Pero ello afecta sólo a algunos sectores del vasto conjunto. 
3) Su rígido carácter de reserva forestal y ganadera, muy vigilado y, diríamos, «tutelado»; quizá también cazadero de temporada.

4) Que siempre, hasta hace poco, han estado rodeadas por carreteras y por los pueblos de sus márgenes, pero nunca atravesadas por ellas, salvo los cordeles ganaderos, y el territorio ni construido ni habitado permanentemente ${ }^{119}$.

5) Que los pueblos están todos situados en la margen izquierda del Ebro, excepto, curiosamente, la Tudela actual (v. supra) y rodean Las Bárdenas de tan peculiar modo que parecen haber nacido o prosperado en función de ella. Entre ellos, Tudela siempre pareció tener preferencia, y hoy sigue siendo su sede ${ }^{120}$.

6) Que al menos desde el siglo XI ha permanecido vinculado, sin saberse la razón ${ }^{121}$, al patrimonio real y, hasta el día de hoy, sigue siendo, al menos nominalmente, estatal. Lo prueba también, cerca ya de Sádaba, el topónimo, casi inevitable dada dada la trayectoria histórica de la zona, de «Bárdena del Caudillo».

El nombre mismo, «bárdena» ${ }^{122}$, lo avisa, pues me parece que debe tener que ver con «barda», «bardal»y «bardar» ${ }^{123}$ : «Remate o cubierta espinosa de muros», por extensión seto o vallado de espi-

119 Es más, parece que se buscaba de intento la despoblación, puesto que podía poner en peligro a la larga la propiedad y el uso comunal. De hecho, en 1538 el procurador fiscal de la Cámara de Comptos de Navarra consiguió que se derribaran unas casas que habían construído en Las Bárdenas algunos vecinos de Tudela.

${ }^{120}$ De hecho, los autores árabes coinciden en la gran extensión de los alfoces de Tudela. Una cita de ibn Galib es expresiva sobre esta extensión, pues dice que «limitan con Huesca» (Vallvé, 1986: 301).

121 J. Elósegui y C. Ursúa (Bardenas, 1990: 10) se preguntan por la causa de la «atípica situación» (y lo es) de que un tan gran territorio no esté sujeto a la jurisdicción de ningún municipio. Sugieren una posible explicación: Que «cuando los distintos pueblos utilizan el territorio, reconocen como propio [scil., de los demás] el que usan y aprovechan sus vecinos, con lo que se van delineando los límites con los pueblos vecinos... De esta forma quedaba un gran espacio vacío, que acaso estaba siendo utilizado conjuntamente... Al no pertenecer a ningún pueblo, pasa al Patrimonio real...». Esta causa, como puede verse, no es válida históricamente. Lo cierto es que no he encontrado la menor referencia de cómo y cuándo empezó la propiedad de la corona de Navarra sobre la reserva; lo que invita, naturalmente, a buscar la causa más atrás, en una vieja consuetudo.

122 Se han apuntado para él orígenes como «pardina» (en dialecto aragonés, el monte bajo de pastos), «barte» (matorral en lengua gascona) e incluso el tan original vascón de «abar-dena» («mata todo»).

${ }^{123}$ Como dije, a veces es mencionado en los documentos como «La Bárdula», y entonces debe surgir el interrogante de su primitiva relación con los bard-ietaì, vard-uli, los modernos vascos. Llama por cierto la atención, hojeando el Madoz, la cantidad de topónimos de territorio vascón que comienzan por bard-. nos, y con «poner bardas a los vallados, paredes o tapias», o tratar de saltar los mismos ${ }^{124}$. Es decir, una zona cercada y/o reservada.

Y ahora, volvamos mil años aún más atrás de la primera de todas estas noticias: ¿Qué otra cosa vemos sino un gran vacío en los mapas de la zona en época romana? Nos falta poder dibujar su interior coloreado de espesos árboles, pero la llamativa ausencia de testimonios epigráficos, funerarios, viarios o miliarios en tan enorme superficie parece advertirnos de que se trataba, también entonces, de una extensísima propiedad, muy reservada en su uso, que ninguna ciudad o vicus ocupa, ni ninguna calzada atraviesa: Una especie de «Bárdena Imperial», de ager Caesarianus, saltus Augusti o, por lo menos, de un ager adsignatus, de uso público y no privado. Naturalmente, no puedo proponer seriamente esta hipótesis, aunque algún pie creo tendría ya para ello, sin presentar alguna prueba más. Voy, pues, a intentarlo.

No sólo la «Bárdena del Rei» o «Bárdenas Reales» se incluían geográfica y administrativamente en la merindad de Tudela, la Tutela romana (que, como hemos visto, tuvo muchas veces en las «hermandades» prelación sobre los otros municipios), sino que, volviendo a los mapas, esta ciudad, aunque hoy al otro lado del ancho Ebro ${ }^{125}$, se encuentra más o menos exactamente en una posición central con respecto a la gran longitud del territorio reservado. Creo haber encontrado el indicio más claro, tanto para el nombre romano de Tudela, Tutela (aparte de en uno de los epigramas de Marcial ${ }^{126}$ ) como para la desconocida identidad de las «Bárdenas» romanas, en los siempre valiosos textos de los agrimensores (Higinio, De condicionibus agrorum G-30, ed. Lachmann, 1848: 114). Es éste:

Assignatae sunt silvae, de quibus ligna in repa-

124 Es curioso que como nombre común «bárdena» no exista en español, con este significado de «sitio muy protegido y bien vallado».

125 Véase lo dicho más atrás sobre la posibilidad de que la Tutela romana se encontrara enfrente, donde no ha sido buscada.

126 Se trata del celebérrimo poema 55 de su libro IV (ed. Loeb, D.R. Shackleton Bailey, Londres, 1993: t. I, 322): ..Grato non pudeat referre versu...Tutelamque chorosque Rixamarum... A. Tovar (1989: C-531) opinaba que ésta debía ser una ciudad desconocida cerca de Bilbilis, pero no olvidemos que, como puesta en la desembocadura de un río nacido en el Moncayo y en la margen derecha del Ebro, Marcial tenía cierto derecho a seguirla considerando celtíbera. Es curioso que casi todos los demás nombres de este poema sí son muestra de los nostrae nomina duriora terrae, pero Tutela en modo alguno, luego debe estar citada por su fama. Y, al ignorar la situación real de todos ellos estos microtopónimos, tampoco podemos saber si estaban cerca o no de su ciudad natal. 
rationem publicorum munerum traherentur. Hoc genus agri TUTELATUM dicitur.

Otros textos, que aluden a este tipo de extensas posesiones, de ager Caesarianus adsignatus (Lachmann, 1848: 247), pueden ayudarnos a precisar la sugerencia en distintos aspectos. Por ejemplo, en cuanto a su modo de propiedad, genérica del emperador ${ }^{127}$. En cuanto a su delimitación, son las tierras llamadas subsiciva (Higinio, ibid.: 132 ss.): Haec ergo subsiciva aliquando auctor divisionis aut sibi reservavit aut aliquibus concessit aut rebus publicis aut privatis personis. Podríamos estar, pues, ante una reserva de tierra asignada a sí mismo por el emperador.

En cuanto a su muy posible falta de divisiones internas, debe ser del tipo del ager arcifinius, descrito bien por Frontino (Lachmann, 1848: 41): At si in agro arcifinio sit (scil., rigor), qui nulla mensura continetur, sed finitur aut montibus aut viis... que nos indica las más viejas formas de delimitar territorios: Ager est arcifinius, qui nulla mensura continetur. Finitur secundum antiquam observationem fluminibus, fossis, montibus, viis... Es decir, que lo habitual en los agri arcifinales (a los cuales solían pertenecer los imperiales y los públicos, y eran más propios de inculta loca) era que no fueran centuriados ni medidos, sino sólo delimitados en su periferia, entre otros medios, por los ríos y por las calzadas.

Esto es, más o menos, lo que vemos en La Bárdena, rodeada por ríos y calzadas, y donde se explican así, en los extremos $\mathrm{O}$ y $\mathrm{E}$, y al menos cuatro veces, los microtopónimos «Cabezo de la Muga», «La Muga», «Tres Mugas», como muestra indefectible de una antigua delimitación periférica ${ }^{128}$. Por fin, en cuanto a su uso, podrá llamarse también ager compascuus cuando no está destinado principalmente al cultivo, sino a otros usos, como son las silvae

${ }^{127} C f$. el artículo ager, de J. Kubitschek, en la $R E$, I $\left(1958^{2}\right)$, cols. $780 \mathrm{ss}$. Gayo (II, 21), al referirse al ager publicus, dice que in eo (provinciali) solo dominium populi Romani est vel Caesaris, según sean las provincias senatoriales (incluida la República) o imperiales. Pero, independientemente de ello, en la forma ahenea de la regio correspondiente debía de figurar de manera más detallada la lex concreta por la que se habría asignado específicamente al emperador una propiedad determinada.

${ }_{128} \mathrm{Y}$, por otra parte, una mayor extensión antigua que la que ahora conserva. Así, al Oeste, zona Norte, el de "Tres Mugas», cerca del Portillo del Trillo y de los expresivos «Cabezo de la Junta» y «Junta Vieja», todo ello hoy, a juzgar por el mapa confeccionado en 1990 por el Gobierno de Navarra, fuera de las Bárdenas. Una bastante detallada descripción de estos amojonamientos para el año 1772 , debida a L. Mariano Díaz, ofrece A. Floristán (1949: 476 ss.), informe en el que, por cierto, se da un perímetro para las Bárdenas entonces de 18 leguas y el ancho entre media y ocho leguas, según las zonas. (bosques), las picariae (pegueras) ${ }^{129}$, la minería (metalla) o la producción de sal (salinae) ${ }^{130}$. Según Sículo Flaco (Lachmann, 1848: 163) se prescribe que tal tipo de territorios debían ser definidos, en las formae o mapas de bronce, y también in situ, como «illi [et ille tot] silvas et pascua, iugera tot...», inscripciones en algunas partes puestas de la finca ${ }^{131}$, que quizá explicaran una advocación mariana (y de la sierra en la que está su ermita) tan poco común como «Nuestra Señora del Yugo»...

Por todo ello, del ager tutelatus que tenía delante, con el cual no podemos saber aún qué vinculación administrativa o de custodia le uniría, pudo perfectamente venirle el nombre al castrum Tutela, la hoy Tudela de La Ribera. Así pues, creo que las Bárdenas de hoy eran en época romana una reserva especialmente forestal, mucho más rica y húmeda, a juzgar por el mucho arbolado que aún le quedaba del siglo XI al XVII, como hemos leído en los textos, y visto en los mapas de Lavanha, Blaeu y De Wit. De esta forma se completa bien la laguna de hallazgos que veníamos observando en los mapas de las figs. 1 y 10 .

Una inteligente medida de previsión tomada por Roma, en pleno centro del valle del Ebro, para garantizar (entre otros usos como la ganadería, las salinas o los cultivos) el abastecimiento continuo de maderas para el uso público y de la comarca, fuera en la minería, en las fraguas de forja para el ejército, en la construcción o, como dice Frontino (de contr. agror., p. 55) para atender el suministro de los baños públicos. Lo cual no impide que fuera a la vez de propiedad imperial ${ }^{132}$, y que, mediante con-

129 Se trata de las industrias de extracción de pez y alquitrán, a partir precisamente de los pinos. Ulpiano, Dig. 50, 16, 17,1 , las menciona entre aquéllas que producen vectigales públicos. La pez servía también, aparte de para el vino y otros usos, para marcar el ganado. Todavía en 1820 los ganados de Las Bárdenas tenían que tener su marca «de pez y de yerro» (Madoz, ibid.).

${ }^{130}$ Tal actividad, según lo dicho más arriba sobre sus sectores con suelos fuertemente salinizados, pudo también tener lugar en zonas concretas de este ager bardenero.

131 Cuando se constituyó la primera «hermandad» de Las Bárdenas, el 31 de Enero de 1204, el acuerdo y la fecha se grabaron «en la estaca que había en la Bárdena» (Madoz, ibid.: 22).

132 Legalmente, nada impediría que hubiera estado asignada a la capital del convento, la vecina Colonia Caesarea Augusta. Pero parece difícil, pues la ciudad de Zaragoza está siempre ausente del usufructo bardenero y de las «hermandades», y no cabe duda de que este modelo de explotación era eco y heredero de otro más antiguo (aunque en este caso, la permanencia árabe y la temprana creación del Reino de $\mathrm{Na}$ varra pudieron borrar huellas anteriores). En cambio, la adsignatio a Zaragoza me parece muy adecuada para una especie de «bárdena» similar, la de los Montes de Castejón y de Zuera y la llanada de El Castellar, conjunto que parece, en una menor superficie, una reserva muy parecida a la navarro- 
cesiones similares (y casi diría que precedentes) el emperador, por medio del oportuno procurator de rango ecuestre ${ }^{133}$ o de un liberto imperial ${ }^{134}$, devengara muy buenos dividendos por permitir su uso ${ }^{135}$. Creo que el hecho de que a fines del siglo XI, expulsados los árabes del territorio, aparezca desde el primer momento documentado como propiedad real habla más en favor de que también en época romana hubiera pertenecido a la ratio privata imperial, y tampoco se hace cuesta arriba pensar que visigodos y árabes respetaron la tradición ${ }^{136}$.

A nuestros efectos, y puesto que se extiende diagonalmente, sus límites eran: El río Ebro al SurSuroeste, la zona baja del río Aragón, hasta Cara, al Noroeste. Al Sureste, el río Arba hasta Segia; mientras que toda la linde NE-N la va cerrando la propia calzada de Tarraco, aquí llamada «de las Cinco Villas». El marco que la contiene se puede recorrer perfectamente por distintas carreteras actuales ${ }^{137}$. Bien entendido que todo el límite externo se rodeaba, como una corona, con los pueblos antecesores de los actuales, que también tendrían franjas para sus pequeños respectivos territorios. Como era fre-

aragonesa. Tiene esta segunda un único punto habitado, otro posible antiguo castellum: El Castejón de Valdejasa, llamado en el mapa de J.B. Lavanha «Castejón de Val de Laça», quien lo dibuja también lleno de arbolado.

${ }_{133}$ En 1358 era el merino de Sangüesa el encargado de dar cuenta ante la tesorería del rey de los emolumentos percibidos por los arrendamientos en las Bárdenas.

134 Aprovecho para anotar que existe, entre la serie de epígrafes votivos a las diosas Tutela, la romana o las indígenas (s.v. en $R E$, XIV, $1965^{2}$, cols. $1600-1603$, por F. Heichelheim) en la antigua Clunia (Coruña del Conde, Burgos) un epígrafe, $C I L$ II 2780 , dedicado, por la salud del emperador Adriano, a la T[utelae] colon(orum) Cluniensium, por un [P. Aeli]us Au[g(usti) l]ib(ertus), sin duda un administrador imperial. No sería raro que se tratara de un caso parecido a éste, puesto que al Norte y al Este de Clunia ( 8 y $3 \mathrm{Km}$.) hay justamente dos singulares topónimos: «Huerta del Rey»e «Hinojar del Rey».

${ }_{135} \mathrm{Y}$ a veces por causas especiales también los concedería gratuitamente, como Felipe III al Monasterio de La Oliva, o Don Carlos de Viana en favor del mismo monasterio y de los pueblos de Carcastillo, Rada y Murillo (Madoz, ibid.: 23).

${ }_{136}$ Tengo la impresión de que en la noticia (extensamente tratada por C. Sánchez Albornoz [1985²: 108] al hablar de los muladíes Banu Qasi, los Casii godos) de que, de la zona oriental de España, Muza sólo dejó sin repartir entre los soldados «el distrito de Ejea», pudiera ocultarse precisamente la noticia árabe más antigua sobre las extensas Bárdenas y su consideración unitaria y regia. Pero carezco de otros elementos para probarlo.

137 Lo que hoy son las C-124 y 125 de Zaragoza, y NA5555 y 124 que, desde Gallur y Tauste, van rodeando perfectamente hacia Ejea y Sádaba para, en Carcastillo, sin cruzar el Aragón, sino siguiendo su margen izquierda, tomar la carretera comarcal a Mélida y Caparroso, saliendo a la N-121, que baja de Pamplona, y nuevamente las regionales NA-134 (Valtierra y Arguedas) y 126 (Cabanillas y Fustiñana), desde donde, pasando a la Z-552, se cierra otra vez el círculo en Tauste, si partimos del límite meridional de Las Bárdenas. cuente en este tipo de reservas, sobre todo de tan gran extensión, tendría cierta diversificación de usos, y, además del arbolado, habría zonas de pastos, útiles para la trashumancia (que hemos visto se daba más moderadamente en el medioevo). El enorme fundus se salpicaría con pequeños alojamientos para pastores, leñadores, guardas, aserradores, campesinos, cazadores o rozadores, todos ellos debiendo encontrar allí hospedaje transitorio. Debía tratarse por lo general de humildes barracones, con sólo lo más imprescindible para pasar desde unos días hasta unos meses en los inviernos. Probablemente (y entonces esperaríamos el patrocinio de Diana), abundara allí también la caza mayor y menor ${ }^{138}$. La fortaleza de Sancho Abarca, construída por Sancho el Fuerte de Navarra, sería sucesora quizá de un pequeño establecimiento de vigilancia romano, para evitar el acceso o la depredación por furtivos ${ }^{139} \mathrm{y}$ personas no legitimadas para el uso, y cumpliría entonces, junto a otras pequeñas garitas y torres en puntos visuales claves, la misión de custodia interna del privado territorio.

He dejado para el final de este apartado la referencia a dos amplios estudios, dos tesis doctorales, con prospección amplia y sondeos o excavaciones puntuales, que sobre la zona navarra de Las Bárdenas se han realizado por fin ${ }^{140}$ en los últimos años, resumidos sobre todo en un largo y reciente artículo (SesmaGarcía, 1994: 89-218), donde se da una imagen de lo allí prospectado desde la Protohistoria hasta la Edad Media. Aunque los autores no se han planteado, obviamente, el problema desde mi punto de vista ${ }^{141}$,

138 Como dice Ovidio, Halieutica, 49: quae densas habitant animalia silvas... Una versión de Gayo en el Dig. 50.16.30.5 es ligeramente diferente: silva est quae pastui pecudum destinata est. La caza se documenta en las Bárdenas, entre otras fechas, en 1532.

139 B. Taracena (1947: 18) refiere del P. Moret los problemas con bandoleros y fascinerosos refugiados en las Bardenas en 1204 , «en el siglo $X V$ » y en 1452 , que requirieron la formación de somatenes y partidas militares.

${ }^{140}$ Hasta ahora, tan grande zona ha merecido muy escasa atención de los estudiosos de la Antigüedad. Véase como ejemplo que la extensa monografía sobre los vascones de $\mathrm{M}^{\mathrm{a}}$ Jesús Peréx, de 1986, no contiene ni una sola alusión a este extenso territorio, aun cuando ocupa buena parte del solar vascón que ella misma tan cumplidamente estudia.

141 Porque, como ellos mismos indican (García García 1992: 204), lo que tratan de demostrar es más bien que «las Bardenas, y concretamente la Blanca, fueron intensamente pobladas desde la protohistoria hasta la Edad Media...» o que (Sesma-García, 1994: 176) «hubo una agrupación numerosa de núcleos rurales romanos...». Es muy de reconocer, no obstante, el mérito indiscutible de prospectar, excavar y estudiar tal cantidad de puntos arqueológicos, pues gracias a ello los modos de ocupación del territorio quedan meridianamente descritos, algo que se desconocía casi por completo ( $\mathrm{si}$ exceptuamos los trabajos de A. Castiella) antes de sus trabajos. 
sus resultados ${ }^{142}$ encajan admirablemente con la propuesta que antes hice de un ager adsignatus, quizá imperial. No puedo ni intentar resumir sus hallazgos y consideraciones. Básteme, pues, comentar los tres aspectos que me han parecido de mayor significación a mi propósito.

Primero, que ellos han encontrado nada menos que 267 de lo que llaman «yacimientos» y yo preferiría llamar sólo «indicios de ocupación y de uso». De éstos, la mayoría, 129, corresponden a las épocas del Bronce y del Hierro, mientras que sólo 56 son romanos (45) o medievales (11). Éste es un fenómeno inverso al habitual (y más viendo como vemos el alto índice de núcleos urbanos que se da en la Ribera navarra y en la Navarra Media romanas), y me parece puede indicar que fue precisamente en la época romana temprana cuando debieron producirse las circunstancias que dieron lugar a la restricción de la propiedad y el uso del territorio.

Segundo, que estos hábitats a mi juicio no alcanzan ni siquiera, a juzgar por las descripciones, el ínfimo rango habitacional, el de «pequeñas casas de campo o granjas» por el que en última instancia se deciden los autores (pág. 185) y, curiosamente, se disponen todos ellos masivamente, entre los siglos 1 y II d.C., a lo largo de los dos principales cordeles de tránsito, al $\mathrm{N}$ y en el centro de la parte de Las Bárdenas que estudian, y no fuera de ellos. Éste parece un tipo de ocupación tal como lo describí más arriba: Totalmente temporal, sin arraigo real y, por otra parte, muy controlado. Parece haber unos lugares de acomodo humano o de estabulación ganadera previstos, y son éstos y no otros los que se han de habitar año tras año. Alguno de estos lugares, como el de El Cantalar I (García García, 1992: 195-205), con su único nivel para cuatro siglos de ocupación, sus modestísimos hallazgos (en los que, naturalmente, predomina la cerámica), y su solitaria punta de lanza, describen perfectamente los que debían ser poco más que puestos de vigilancia interna, que ni siquiera está claro que fueran militares en sus fases altoimperiales.

El tercer dato interesante a mi propósito es el único análisis polínico para niveles romanos realizado en el vasto territorio (Sesma-García, 1994: 188). A comienzos del siglo II las especies predominantes eran las de ribera: Sauces, alisos, pinos, coscojas, juncias (y ciperáceas en general) y plantas buenas

142 Me refiero, como es lógico, a la época romana especialmente, puesto que de la medieval ya se podía tener una idea muy aproximada sólo con leer los documentos que Madoz recogía. para el pasto. Dedujo la autora del análisis que debía haber un cauce permanente de agua en las cercanías. Las juncias, sobre todo, sólo se dan en ambientes muy húmedos ${ }^{143}$. Y estos resultados nos devuelven a los textos del siglo XI y a los mapas del XVII, por los que ya suponíamos que en época romana debía haber en Las Bárdenas muchas más corrientes de agua y un más bien intenso arbolado, que haría del forestal y derivados el uso principal de este extenso ager, aparte de que hubiera trashumancia estacional, ganadería permanente o incluso cultivos cerealísticos aislados.

Así pues, estos amplios y meritorios estudios, aunque tuvieran otros objetivos, confirman en mi opinión un tipo de usos restringidos, controlados y muy superficiales, que no inciden de verdad sobre el territorio ni lo modifican. Ello es lo que correspondería a un ager tutelatus, como propuse más arriba. En este sentido debo discrepar de la principal conclusión de los autores, puesto que siempre se describieron Las Bárdenas Reales como un «desierto poblacional» $\mathrm{y}$, en el sentido estricto de lo que puede considerarse sociológica o económicamente una «población», el estudio arqueológico creo que no ha desmentido en absoluto la definición previa ${ }^{144}$.

Pienso, para terminar, que si se confirmaran las hipótesis más arriba expuestas, basadas en la toponimia, los mapas de «no-hallazgos», los textos medievales y modernos, la cartografía del siglo XVII, los agrimensores romanos y, por último, la arqueología, en la reserva forestal y pecuaria romana de Las Bárdenas Reales tendríamos uno de los mejores y más bellos ejemplos de continuidad de un modelo de propiedad y explotación antiguas que puedan encontrarse hoy en nuestro país ${ }^{145}$, aunque muy lamentablemente degradado. Y en todo caso Tutela, Tudela, que es por donde comencé estas reflexiones, encontraría una muy adecuada justificación toponímica si era, como lo fue después y lo es hoy, la principal base de control, gestión y/o vigilancia de un inmediato ager tutelatus. Y máxime si, como más arriba he apuntado, pudo alzarse antiguamente en la propia margen izquierda del Ebro.

${ }^{143}$ Se añade además que otros análisis polínicos para las fases pre- y protohistóricas arrojan la conclusión de que el ambiente era todavía más húmedo que en época romana.

144 Es muy significativo, por ejemplo, que no se encuentren enterramientos, a pesar de que en los fundos privados sí era costumbre hacerlos.

145 Tal como expuse hace ya años (Gerión 7, 1989: 183 ss. y fig. 1), el últimamente polémico coto o reserva estatal de Anchuras (hoy de la provincia de Ciudad Real) debía corresponderse en época romana con la praefectura Ucubitana, adsignata a la colonia cesariana de Ucubi (Espejo, CO.) en pleno territorio de Augusta Emerita y contigua a la praefectura Turgaliensis de ésta. 


\section{5) Bascunes $=$ ¿Rocaforte, Pamplona?}

Queda, por último, el caso de Bascunes/Barscu$n e{ }^{146}$, conocida hasta ahora sólo por sus amonedaciones del grupo navarro, con sus característicos reversos de jinete con espada. Como ya dije, los mayores lotes de monedas con procedencia de este letrero indígena son de Alagón y de Tafalla ( $c f$. supra), mientras que aparecidas en Pamplona, la capital de los vascones, sólo contamos con tres. Pero bien puede ser una circunstancia accidental y no concluyente, puesto que Alagón es Alauo y hemos propuesto Curnonion para Tafalla.

El parecido de Bascunes con Vascones, a pesar de la vacilación $b / v$, resulta tan atractivo que resulta difícil no aceptar que fuera el nombre anterior de Pompaelo, pues éste no podía ser el indígena ${ }^{147} \mathrm{y}$, como bien da a entender Estrabón (III, 4, 10), ella era «la ciudad de los vascones». Encontré también en este mismo sentido una noticia interesante de ibn Hayyan (1981: 150), en la famosa aceifa de Pamplona, del año

146 Sobre esta ceca $v$. por último Villaronga, 1995: passim y espec. 98-99. La conocida vacilación Basc-/Barsc- debería resolverse en favor de la primera, a la vista de teónimos como el hallado en Aquitania: Deo Bascei Andosso (a otro propósito citado por Gorrochategui-Lakarra, 1996: 120).

${ }_{147}$ No deja de resultar extraño, sin embargo, que se cambiara el nombre a una ciudad indígena relevante, porque no encaja con la política habitual romana de denominación de ciudades que no se erigían ex novo, como parece ésta. Y me parece igualmente raro que se permitiera memoria tan notable del peor enemigo de César. No es éste es lugar para tratarlo, pero Estrabón (III, 4, 10), la única fuente, no aclara qué Pompeyo es el fundador de Pamplona. Personalmente, dudo mucho que Pompeyo el Grande con todo su imperium fundara una ciudad con su propio nombre que en el año 57 d.C. aún se denomina civitas (CIL II 2958) y en época de Vespasiano sigue siendo estipendiaria (Plinio III, 4, 24). Se podría defender acaso algún tipo de preterición estatutaria por causa de su origen, pero también se me ocurre que no se debería descartar como fundador algún Pompeyo anterior, como el primer cónsul de la familia, Cn. Pompeius, que en 141 a.C. pacta un foedus inconcluso con los numantinos (Liv., Epit. 54, i. a.); o incluso que fuera el padre del Magno, Cn. Pompeius Strabo, el autor del licenciamiento de la turma Salluitana. Sobre él, Fr. Miltner en RE, XXI.2, col. 2254 ss: No sabemos casi nada de su actividad entre el 93 (en que es pretor con su padre, en Macedonia) y el 90 a.C., en que aparece ya comandando una de las legiones del norte de Italia. Se duda si pudo administrar Sicilia en estos tres años, pero quizá tuvo algún destino desconocido en la Citerior. Y está claro que la turma Salluitana de la guerra del 9089 a.C. se había reclutado antes, entre ciudades ya con cierto nivel de fidelidad, incluídas varias vasconas. Sin ir más lejos, el pacto de hospitalidad citado (II 2958) que los pompelonenses suscriben en el 57 d.C., es una renovatio (por tanto de un pacto ya antiguo) con un L. Pompeius Primianus (no Cnaeus, Caius ni Sextus), a primera vista de Caesaraugusta, a juzgar por su tribu Aniensis (aunque uno de los legados, no sabemos si pompelonés, sí es Sextus, y además Nepos). Parecen quedar, en torno al fundador de Pamplona, algunos interrogantes...
924: An-Nasir llegó por fin a devastar la ciudad de Banbaluna, la cual «da nombre a la región». Como no tenemos constancia para el país de un nombre similar a Pompaelonia ${ }^{148}$, cabe pensar que éste al que se refiere Hayyan fuera Bascones/Vasconia. Hay, por tanto, algunos indicios en favor de Pamplona.

Pero una segunda alternativa mejor, para la que he encontrado también elementos, la representaría el actual Rocaforte, con su dios Peremusta, «el más alto». Rocafort se ubicaba defendiendo el llamado en época medieval «paso de los Vascones», ruta obligada para el acceso desde el SE a Pamplona y el saltus, una vez pasada Sangüesa. En efecto, el mismo Ibn-Hayyan (1981: 149), en la ocasión recién referida, llama al paso por el que an-Nasir penetra hacia Lunbira (Lumbier) y Pamplona, el «Fayy al-Baskuns», «el desfiladero o paso de los Vascones», y a la población junto a él, «Baskunsa». Unos autores interpretan que ésta, patria del rey Sancho, es Sangüesa ${ }^{149}$ y otros que Rocaforte (ibn Hayyan, 1981: 146). Pero como ibn Hayyan la llama «aldea», y los árabes ya habían superado el paso, encontrándose en «altos montes y solitarias cimas», creo más posible que se refiera a Rocaforte. Así, Bascunes se encontraría en el punto de control y acceso al corazón del territorio vascón. De las dos hipótesis posibles es ésta, sinceramente, la que más me convence, debido sobre todo a la denominación árabe de Rocaforte-Sangüesa como Baskunsa, que no puede ser más expresiva de su posible nombre anterior: Vascones.

\section{EPÍLOGO}

Con el mapa de la fig. 13 concluyo ubicando estos 19 posibles nuevos emplazamientos para las distintas ciudades, pasos y territorios que he venido analizando, sumados los indicios de miliarios, calzadas, textos, monedas y otros restos arqueológicos. Como puede verse, por grande y bienintencionado que sea el esfuerzo, la mies sigue siendo inabarcable. Repasando las listas de topónimos medievales (Corona, 1947), se perciben muchos ecos de los que

${ }^{148}$ Salvo que se esté refiriendo sólo a la cuenca de Pamplona, pero no lo creo.

149 Vetus Sancosa, es decir, la vieja Sangüesa, llamaba Ceán Bermúdez (1832: 153) a Rocaforte (el Rocafort de los mapas del XVII), recogiendo viejas tradiciones del pueblo. Según otros, se llamó Suessa (Fatás, 1971: 119). Pero Sangüesa es posterior a Rocaforte, que parece su núcleo primitivo. De hecho, aquélla es muy citada en documentos medievales (Corona, 1947: 113-114), sobre todo como Sangossa (var. Sancuesa, Sanchuesa, Sanguessa y Sanguossa), mientras que no se cita ya en ellos la fortaleza de Rocafort. 




Fig. 13.-Ensayo final de identificación de 20 ciudades y lugares vascones, a partir de los datos de Ptolomeo y otras fuentes textuales y arqueológicas (mapa de A. Canto y S.

$$
\text { Luzón). }
$$

les precedieron. Lamentablemente, quedan otras muchas ciudades de aún más incierta identificación. Es fácil pensar, como ya se ha dicho muchas veces, que los Iluberritani, con su dios Ilumberri (CIL XIII, 42) vivían en Lumbier, la Lunbira árabe, dominando la ruta, más difícil, que se dirigía hacia la entrada SE de Pamplona. Y quizá sea también factible la posibilidad que he apuntado antes, de que Estella/Irache, con el importante centro neurálgico de Montejurra, se corresponda con Araceli.

Pero ¿estaban también aquí los Calagurritani qui et Fibularenses de Plinio? ¿Cuántas ciudades importantes por su epigrafía, materiales arqueológi$\cos$ o su significación nos quedan sin un nombre antiguo que atribuirles? Pienso en interesantes enclaves, incluso con miliarios, como Eslava, o en Barbarín, con sus tres dedicaciones al dios Selatse. ¿Cómo se llamaron en realidad las ciudades santas de San Martín de Unx y de Ujué? ¿Qué nombre devolver a Sos del Rey Católico, que tanto recuerda a los suesetanos pero está en zona vascona, y por donde también pasaba una calzada? ¿El Sisso vascón de 
Ceán Bermúdez? Y, a la inversa, ¿dónde estuvo la Vativesca criadora de los toros de Marcial ${ }^{150}$ ? ¿Y la Bentian monetal?

¿Qué llamar al propio Javier, a Aibar, a Artajona, a Aoiz o a la tan original Aguilar de Codés? ¿Quizá Cuda/ense, como las Coa galaico-portuguesas? ¿Tendrá algo que ver con el letrero Ben-coda en los anversos de Bascunes y Bentian? ¿Será una confederación o, mejor, un magistrado común? ¿Acaso conserva el topónimo actual, Larraga, el teónimo Larrahe de la vecina Andión? El pueblecito de Sunbilla, sobre la via XXXIV, entre Pamplona y Oyarzun, ¿será eco de una perdida Summa Villa? ¿Pudo el jinete Illuersensis, encuadrado en la turma Salluitana pompeyana (CIL I $709=\mathrm{I}^{2}$, IV, p. 936, 15 ss.), haber nacido en Luesia, el pueblo de tan bello nombre, al $\mathrm{N}$ de Farasdués, entre su río y sierra del mismo nombre? Deben de ser los mismos Ilursenses estipendiarios de Plinio ${ }^{151}$. Esta última reducción sí me parece de fácil defensa.

Para la época romana seguramente podrían aplicársele a la Navarra Media, casi toda ella ager Vas conum, las mismas definiciones que, para el ámbito geográfico actual, le aplicaba S. Mensúa Fernández, en su excelente estudio de 1960 (pp. 14-15): «Situada en el contacto entre la Depresión del Ebro y las primeras sierras pirenaicas del sector navarro, la Navarra Media es una región de transición, de empalme... que matiza la oposición física y humana entre el Pirineo y las bajas llanuras del Ebro... escalón topográfico intermedio... Entre las tierras esteparias que circundan el Ebro y las tierras francamente oceánicas de abundantes y regulares precipitaciones. Límite entre las especies arbóreas atlánticas y los matorrales xerófilos».

Y también en lo histórico: «Frontera que señala la estabilización de las conquistas árabes... tierra de nadie... Cuando Tudela es recuperada para el reino cristiano [siglo XII], la Navarra Media sigue siendo una zona de fricción entre Navarra, Castilla y Aragón... Las fronteras lingüísticas entre el vasco y el castellano pasan por nuestra región hasta la Edad Moderna...» Transición también en el tipo de poblamiento humano: «Encontramos aquí, junto a grandes núcleos, con una cierta organización urbana en plano... las formas de dispersión en pequeñas aldeas

\footnotetext{
${ }^{150}$ Cf. supra nota 17.

151 Me parece más fiable la lectura Illuersensis, en el bronce de Ascoli, que la tradición manuscrita Ilursensis de Plinio, del mismo modo que ocurre con los ascolitanos $L i$ benses, también desconocidos «entre los Pirineos y el Ebro» (Tovar, 1989: C-634, de una Liba distinta de la Libia berona). ¿Sería, ya por último, el monasterio de Ntra. Sra. de la Oliva (un árbol no muy representativo de la región) evocación de una antigua Liba?
}

y caseríos agrupados en valles, propias de la montaña...»Y la transición agraria: «Entre dos zonas de cerealistas de monocultivo, la Navarra Media conserva el antiguo policultivo de cereales, viñedo y olivar... Con un fondo de dominio de la pequeña propiedad, coexisten las grandes... Conviven también en la explotación ganadera los sistemas de organización de pastos de ambos orígenes, la montaña y la Ribera...» Eslabón de enlace, vía de contacto, vehículo de intercambio y comunicación, con rutas trashumantes e importantes ferias y mercados, donde se encuentran para comerciar montañeses y ribereños. Así exactamente, porque la geografía y la topografía siempre se han impuesto sobre el hombre y los lugares donde habita, debió ser el ager Vasconum, crisol de culturas y lenguas mucho antes de que los romanos clavaran allí sus enseñas y ellos tuvieran que comenzar a ser trilingües. Pero debieron hacerlo sin grandes dificultades. Porque las zonas de transición tienen los hábitos de adaptación muy arraigados.

\section{BIBLIOGRAFÍA}

Aguarod Otal, M. C. y Mostalac Carrillo, A (1983): «Nuevos hallazgos de aras taurobólicas en la provincia de Zaragoza», Homenaje al Prof. Martín Almagro Basch, Madrid, 311-329.

Albertos, $M^{a}$ L. (1972): La antroponimia en las inscripciones hispanorromanas del País Vasco, Estudios de Deusto 20, fasc. 46, 335-356.

AldecoA LeCANDA, J. (1965): Nueya leyenda ibérica, Numisma 73, 15-17.

Arias Bonet, G. (1968): Algunas calzadas de Hispania a Aquitania, El miliario extravagante 14, 426-440.

Arqueología (1992): VV.AA. Arqueología 92. Catálogo y guía, Museo Provincial de Bellas Artes, Zaragoza.

Asensio Esteban, J. A. (1995): La ciudad en el mundo prerromano en Aragón, Zaragoza.

Al-BAKRI (1982): Geografía de España, ed. de E. Vidal (col. Textos Medievales $n^{\circ} 53$ ), Zaragoza.

BAÑAles LeOZ, J. M ${ }^{\mathrm{a}}$ y M. (1992): Nuevos restos romanos en Artajona, Actas del II Congreso General de Historia de Navarra (Pamplona, 1990), Príncipe de Viana, anejo 14.2, 183-194.

BardenAs (1990): VV. AA., Las Bardenas Reales (Depto. de Ordenación del Territorio, Vivienda y Medio Ambiente del Gobierno de Navarra), Pamplona.

Beltrán, A. (1987): Nota sobre las acuñaciones ibéricas en Navarra, Actas del I Congreso General 
de Historia de Navarra (Pamplona, 1986), Príncipe de Viana, anejo 7, 342.

Beltrán-Velaza (1993): F. Beltrán y J. Velaza,

- Una nueva inscripción ibérica sobre bronce (Aranguren, Navarra), Aurea saecula. Studia Palaeohispanica et Indogermanica J. Untermann ab amicis Hispanicis oblata, Barcelona, 89-99.

Blázquez, J. M. (1975): Diccionario de las Religiones Prerromanas de Hispania, Madrid.

Blázquez, J. M. (1983): Religiones Prerromanas (Primitivas religiones ibéricas, t. II), Madrid.

Bost, J.-P. y FABre, G. (1988): Aux origines de la province de Novempopulanie: Nouvel examen de l'inscription d'Hasparren, Aquitania 6, 167178.

Canto, A. M ${ }^{\text {a }}$; Iniesta, J.; Ayerra, J. (1997, e.p.): Epigrafía funeraria inédita de un área romana inédita: Tafalla y el valle del río Cidacos (Navarra), Cuadernos de Arqueología de la Universidad de Navarra 5.

CAnto, A. Ma (e.e.): Fuentes árabes para la Hispania romana, en elaboración.

CARo Baroja, J. (1945): La significación de algunas danzas vasco-navarras, Príncipe de Viana, 115132.

Caro Baroja, J. (1996); Navarra, Etnología de las Comunidades Autónomas, Madrid, 465-516.

Castiella Rodríguez, A. (1986): Nuevos yacimientos protohistóricos en Navarra, Trabajos de Arqueología Navarra 5, 133-173.

Castiella Rodríguez, A. (1989): Monedas prerromanas en Navarra, Actas del XIX Congreso Nacional de Arqueología, vol. I, Zaragoza, 675-682.

Castilla Brazales, J. (1992, ed.): La crónica de Arib sobre Al-Andalus, Granada.

Castillo et al.: Castillo, C.; Gómez Pantoja, J. y MAULEÓN, $\mathrm{M}^{\mathrm{a}}$ D. (1981): Inscripciones romanas del Museo de Navarra, Pamplona.

Códice Valencia (1983): Claudio Ptolomeo. Cosmografía. Códice Latino de la Biblioteca de la Universidad de Valencia (S. XV), Valencia.

Corona BARATECH, C. E. (1947): Toponimia navarra en la Edad Media, Huesca.

CoRTÉs y LóPEZ, M. (1835): Diccionario geográficohistórico de la España Antigua Tarraconense, Bética y Lusitana, t. I, Madrid.

DupRÉ, N. (1995): Remarques sur l'hydronymie du bassin de l'Ebre à l'époque romaine, Mélanges Raymond Chevallier, Caesarodunum (29, 2.2.), 15-31.

EloRzA, J. C. (1970): Estelas romanas en la provincia de Álava (Estudios de Arqueología Alavesa 4), 235-250, Madrid.
Elorza, J. C. (1972): Religiones del país vasco-navarro en época romana, Estudios de Deusto 20, fasc. 46, 357-366.

Esteban Delgado, M. (1990): El país vasco-atlántico en época romana, San Sebastián.

Etayo, J. (1926): Vestigios de población ibero-romana cabe Arguedas, Boletín de la Comisión Provincial de Monumentos de Navarra 17, 8490.

FatÁs CABEZA, G. (1971): Sobre suessetanos y sedetanos, AEspA 44, 109-125.

Fatás Cabeza, G. (1972): Aproximación al estudio de la expansión vascona en los siglos II y I antes de Cristo, Estudios de Deusto 20, fasc. 46, 383390.

Fatás Cabeza, G. (1975): Una estela de guerrero con escudo escotado en $\mathrm{V}$ aparecida en las Cinco Villas de Aragón, Pyrenae 11, 165 ss.

Fernández OchoA, C. y Morillo Cerdán, A. (1994): De Brigantium a Oiasso, Madrid.

FLORISTÁn, A. (1949): Una descripción de las Bardenas Reales en el siglo XVIII, Príncipe de Viana 37, 475-481.

Galán Domingo, E. (1993): Estelas, paisajes y territorio en el Bronce Final del Suroeste de la Península Ibérica (Complutum, vol. extra 3), Madrid.

García García, Ma L. (1992): Avances sobre el poblamiento romano en las Bardenas Reales de Navarra, Actas del Segundo Congreso General de Historia de Navarra (Pamplona 1990), Príncipe de Viana, anejos ${ }^{\circ} 14$, II, 195-205.

García Gelabert, M. P. y Blázquez, J. M. (1994): Estelas funerarias con retratos, Actas del V Congreso Internacional de Estelas Funerarias (ed. C. de la Casa), Soria, 309-321.

Gil, J., Moralejo, J. L. y Ruiz de la Peña, J. I. (eds.) (1985): Crónicas Asturianas (Universidad de Oviedo, Depto. de Historia Medieval), Oviedo.

Gimeno, H. (1989): Inscripciones inéditas en manuscritos de la Biblioteca Nacional, Veleia 6, 235241.

Gimeno, H. y Velaza, J. (1994): Correcciones de lectura a algunas inscripciones romanas de $\mathrm{Na}$ varra, Anuari de Filología 17, 189-200.

Gómez-Pantoja, J. (1994): Estelas y blasones, Actas del V Congreso Internacional de Estelas Funerarias (ed. C. de la Casa), Soria, 371-376.

GonzÁlez, M. C.; Loizaga, J. M. y Relloso, F. (1987): Ensayo de sistematización de la epigrafía romana de Navarra, Actas del I Congreso General de Historia de Navarra (Pamplona, 1986) Príncipe de Viana, anejo 7, 422. 
Gorrochategui, J. (1987): Situación lingüística de Navarra y aledaños en la Antigüedad, Actas del I Congreso General de Historia de Navarra (Pamplona, 1986) Príncipe de Viana, anejo 7, 437 y 443.

Gorrochategui, J. y LaKarra, J. (1996): Nuevas aportaciones a la reconstrucción del Protovasco, Actas del VI Coloquio sobre Lenguas y Culturas prerromanas de la Península Ibérica (Coimbra 1994), edd. F. Villar y J. d'Encarnação, Salamanca, 101-145.

GuAdÁn, A. M. de (1969): Numismática ibérica e ibero-romana, Instituto Español de Arqueología C.S.I.C., Madrid.

Guía (1923): Comité de Iniciativa y Propaganda de Navarra. Guía Oficial, Pamplona.

IBN-HAYYAN (1981): Crónica del califa Abdarrahman III an-Nasir entre los años 912 y 942 (alMuqtabis V), ed. M ${ }^{\mathrm{a}} \mathrm{J}$. Viguera y F. Corriente (col. Textos Medievales no 64), Zaragoza.

Hernández Pacheco, F. (1949): Las Bardenas Reales. Rasgos fisiográficos y geológicos, Príncipe de Viana 37, 427-440.

Al-IDRISI (1974): Geografía de España, ed. E. Saavedra (Madrid 1881), con prólogo de A. Ubieto (col. Textos Medievales $n^{\circ} 37$ ), Valencia.

ILER (1971): J. VIVES, Inscripciones Latinas de la España Romana, Barcelona.

Jimeno JuRío, J. M. (1968): Documentos medievales artajoneses, Pamplona.

JuLIÀ, D. (1971): Étude épigraphique et iconographique des stèles funéraires de Vigo, Heidelberg.

Jusué Simonena, Ma C. y Ramírez Vaquero, E. (1994): Olite, ed. Comunidad Foral de Navarra (serie Panorama ${ }^{\circ} 12$ ), Pamplona.

Labe Valenzuela, L. F. (1987): Las cecas ibéricas en Navarra, Actas del I Congreso General de Historia de Navarra (Pamplona, 1986) Príncipe de Viana, anejo 7, 449-450.

LaChMAnN, K. (1848): Gromatici veteres, Berlín.

LADRERO, E. (1927): El culto al toro en la antigua Iberia, Boletín del Museo Provincial de Bellas Artes de Zaragoza 13, 30-33.

Liz Guiral, J. (1985): Puentes romanos en el convento jurídico caesaraugustano, Zaragoza.

López Melero, R. (1987): Una deditio de vascones, Actas del I Congreso General de Historia de Navarra (Pamplona, 1986), Príncipe de Viana, anejo 7, 469.

Lostal Pros, J. (1992): Los miliarios de la provincia Tarraconense, Institución Fernando el Católico, Zaragoza.

Madoz, J. (1945): El viaje de San Eulogio a Navarra, Príncipe de Viana 20, 415-423.
MADOZ, P. (1849): Diccionario geográfico-estadístico-histórico, tt. IV, XIII, Madrid (y reed.: «Navarra», Valladolid 1986).

Magallón Botaya, Ma A. (1987): La red viaria romana en Aragón, Zaragoza.

Mañaricúa, A. E. de (1972): Fuentes literarias de época romana acerca del pueblo vasco, Estudios de Deusto 20, fasc. 46, 221-239.

Marco, F. (1993): Nemedus Augustus, Aurea saecula. Studia Palaeohispanica et Indogermanica J. Untermann ab amicis Hispanicis oblata, Barcelona, 165-178.

Marco Simón, F. (1978): Las estelas decoradas de los conventos caesaraugustano y cluniense, Zaragoza.

Marcos Pous, A. y García Serrano, R. (1972): Un grupo unitario de estelas funerarias de época romana con centro en Aguilar de Codés (Navarra), Estudios de Deusto 20, fasc. 46, 317328.

Martín Bueno, M. (1977): Aragón arqueológico: Sus rutas, Zaragoza.

Meneses, A. de (1976): Reportorio [sic] de caminos (Alcalá de Henares, 1576), Colección Primeras Ediciones $n^{\circ} 6$, Madrid.

Mensúa Fernández, S. (1960): La Navarra Media Oriental. Estudio geográfico, Zaragoza.

Mezquíriz, Ma A. (1993-1994): La villa de las Musas (Arellano-Navarra). Estudio previo, Trabajos de Arqueología Navarra 11, 55-100.

Miguel de Hermosa, A. R. de (1992): De Pompaelo a Imus Pyrenaeus, Actas del Segundo Congreso General de Historia de Navarra (Pamplona 1990), Príncipe de Viana, anejos $n^{\circ} 14$, t. II, $259-$ 265.

Molina, L. (1984): Una descripción anónima de alAndalus, t. II. Instituto de Estudios Árabes del CSIC, Madrid.

MLH 1975: J. Untermann, Monumenta linguarum Hispanicarum. I.1/2: Die Münzlegenden, Wiesbaden.

Moret, J. de (1987): Anales del Reino de Navarra [Pamplona, 1665 1 1766 ${ }^{2}$ ] (ed. S. Herreros), t. I, Pamplona.

MünSTER, S. (1540): Claudius Ptolemaeus. Geographia, ed. Basilea (reed. 1966, Amsterdam).

Oliver Asín, J. (1971): Orígenes de 'Tudela', Homenaje a Don José Esteban Uranga, Pamplona, 495-513.

Peréx Agorreta, Ma J. (1986): Los vascones. El poblamiento en época romana, Institución Príncipe de Viana, Pamplona.

Peréx, Ma J. y Unzu, M. (1987): Notas sobre la posible localización de Iturissa (Espinal-Navarra), 
Actas Primer Congreso General de Historia de Navarra (Pamplona 1986), Príncipe de Viana, anejo $\mathrm{n}^{\mathrm{o}}$ 7, vol. II, 555.

PÉREZ DE LABORDA, A. (1985): Una calzada romana a lo largo del valle del Arga, Trabajos de Arqueología Navarra 4, 145-155.

Puertas Tricas, R. (1975): Iglesias hispánicas (siglos IV al VIII). Testimonios literarios, Patronato Nacional de Museos, Madrid.

Ruiz-Gálvez Priego, Ma L. y Galán Domingo, E. (1991): Las estelas del Suroeste como hitos de vías ganaderas y rutas comerciales, Trabajos de Prehistoria 48, 257-273.

SÁnchez Albornoz, C. (1976²): Vascos y navarros en su primera historia, Madrid.

SÁnchez Albornoz, C. $\left(1985^{2}\right)$ : Orígenes del reino de Pamplona. Su vinculación con el Valle del Ebro, Institución Príncipe de Viana, Pamplona.

Sayas Bengoechea, J. J. (1994a): Los vascos en la Antigüedad, Madrid.

SAYAS, J. J. (1994b): La religiosidad de los pueblos de ambas vertientes de los Pirineos, en J.M. Blázquez et al., Historia de las religiones de la Europa antigua, Madrid.

Schulten, A. (1958, 1963): Geografía y etnografía antiguas de la Península Ibérica I-II, Madrid.

Sesma Sesma, J. (1993): Aproximación al problema del hábitat campaniforme: Las Bárdenas Reales, Cuadernos de Arqueología de la Universidad de Navarra 1, 53-119.

Sesma, J. y García, Ma L. (1994): La ocupación desde el Bronce antiguo a la Edad Media en las Bardenas Reales de Navarra, Cuadernos de Arqueología de la Universidad de Navarra 2, 89-218.

TAFALLA (1990): VV.AA., Tafalla, 350 años como ciudad (ciclo de conferencias), Cuadernos de Cultura Tafallesa 5, Casa de Cultura, Tafalla.
Taracena, B. (1947): Una Torre en las Bardenas Reales, Príncipe de Viana 26, 13-19.

Taracena, B. y VÁzquez de Parga, L. (1943): Excavaciones en Navarra.I. Exploración del 'Castejón’ de Arguedas, Príncipe de Viana 10, 129. 159.

Taracena, B. y Vázquez de Parga, L. (1947): Excavaciones en Navarra. 1 (1942-1946), Pamplona.

Terés, E. (1986): Materiales para el estudio de la toponimia hispanoárabe. Nomina fluvial, t. I., Instituto de Estudios Árabes, CSIC, Madrid.

Tovar, A. (1989): Iberische Landeskunde II.3. Tarraconensis, Baden-Baden.

Unzueta Portilla, M. (1996): El período romano en la vertiente cantábrica de la Comunidad Autónoma vasca, Los finisterres atlánticos en la Antigüedad, Gijón-Madrid, 165-170.

Uranga, J. E. (1966): El culto al toro en Navarra y Aragón, Problemas de la Prehistoria y de la Etnología Vascas: Actas del IV Symposium de Prehistoria Peninsular, 223-231, Pamplona.

VALlVÉ, J. (1986): La división territorial de la España musulmana, Instituto de Estudios Árabes, CSIC, Madrid.

Vaughan, C. R. (1987): Viaje por España (1808), ed. de M. Rodríguez Alonso. Ediciones de la Universidad Autónoma de Madrid, Madrid.

VÁzquez de Parga, L. (1943): La División de Wam$b a$, CSIC, Madrid.

Villaronga, L. (1995): Denarios y quinarios ibéricos. Estudio y catalogación, Barcelona-Madrid.

Villuga, P. J. (1967): Reportorio [sic] de todos los caminos de España, [Medina del Campo, 1546], Nueva York.

Vives, J. (1963), ed.: Concilios visigóticos e hispano-romanos, Barcelona-Madrid. 